\title{
Risks and Returns of Cryptocurrency
}

\author{
Yukun Liu and Aleh Tsyvinski*
}

August 13, 2018

\begin{abstract}
We establish that the risk-return tradeoff of cryptocurrencies (Bitcoin, Ripple, and Ethereum) is distinct from those of stocks, currencies, and precious metals. Cryptocurrencies have no exposure to most common stock market and macroeconomic factors or to the returns of currencies and commodities. In contrast, we show that the cryptocurrency returns can be predicted by factors which are specific to cryptocurrency markets - there is a strong time-series momentum effect and proxies for investor attention strongly forecast cryptocurrency returns. Finally, we create an index of exposures to cryptocurrencies of 354 industries in the US and 137 industries in China.
\end{abstract}

*Yale University. We thank Andrew Atkeson, Nicola Borri, Eduardo Davila, Stefano Giglio, William Goetzmann, Andrew Karolyi, Stephen Roach, and Robert Shiller for their comments. 


\section{Introduction}

Cryptocurrency is a recent phenomenon that is receiving significant attention. On the one hand it is based on a fundamentally new technology, the potential of which is not fully understood. On the other hand, at least in the current form, it fullfils similar functions as other, more traditional assets. Is cryptocurrency a form of a currency, a commodity, a stake in a technology breakthrough, or a completely different instrument? Can cryptocurrency be priced by the factors available for other asset classes? Which industries may be affected by the development of blockchain technology?

Academic attention so far has has mostly focused on developing theoretical models of cryptocurrencies. This paper is the first comprehensive analysis of cryptocurrencies through the lens of empirical asset pricing. Its contribution is twofold. First, it establishes a set of basic asset pricing facts for this asset class. Second, these facts provide a common benchmark that the existing and future models of cryptocurrencies should take into consideration.

One way to understand what cryptocurrencies represent is to investigate whether their returns behave similarly to other asset classes. In other words, we assess how investors and markets value current and future prospects of cryptocurrencies. We use standard tools of empirical asset pricing to comprehensively analyze cryptocurrency risks and returns. Specifically, we study whether major cryptocurrencies comove with stocks, currencies, commodities, macroeconomic factors, and the cryptocurrency market specific factors. Our main conclusion is that only cryptocurrency market specific factors - momentum and the proxies for investor attention - consistently explain the variations of cryptocurrency returns. This suggests, in contrast to popular explanations, that markets do not view cryptocurrencies similarly to standard asset classes.

We focus on three of the five major cryptocurrencies - Bitcoin, Ripple, and Ethereum ${ }^{1}$ - and start by documenting the characteristics of cryptocurrency returns. We observe that the mean and the standard deviation of returns are an order of magnitude higher than those for the traditional asset classes. For example, the weekly mean return on Bitcoin is 3.79 percent with a standard deviation of 16.64 percent. The Sharpe ratios at the daily and weekly levels are about 50 percent and 75 percent higher, and at the monthly level are comparable to those of stocks. The returns have positive skewness increasing with the frequencies from daily to monthly. The returns experience high probabilities of "disasters" and "miracles". For example, a "disaster" of the daily 20 percent negative return on Bitcoin happens with the probability of 0.5 percent while a "miracle" of the same size happens with the probability of almost 1 percent.

We first investigate whether the cryptocurrency market behaves similarly to the stock market. We test this by studying whether the returns on the cryptocurrency market are compensated by the risk factors derived from the stock market. We show that the CAPM betas are sizable but the alphas remain large and statistically significant. The exposures to other common risk factors in the stock market are very small. Specifically, the exposures to Fama French five risk factors are low and not statistically significant. Compared to Bitcoin, Ripple and Ethereum have higher unconditional alphas, a smaller CAPM beta, and a strong exposure to the HML factor. We also explore 155 other factors documented in the finance literature and find no discernible patterns of loadings.

Second, we study the exposure of cryptocurrency returns to major currencies (Australian Dollar, Canadian Dollar, Euro, Singaporean Dollar, and UK Pound). This aims to test a popular view that cryptocurrency may serve as another medium of exchange. Although these major currenices strongly comove, we find that the exposures of all cryptocurrencies to these currencies are small and not statistically significant.

\footnotetext{
${ }^{1}$ The other two largest cryptocurrencies by market capitalization are BitcoinCash and Litecoin which are derived from, and thus behave similarly to, Bitcoin.
} 
Third, we study the exposure of cryptocurrency returns to precious metals commodities (gold, platinum, and silver). This aims to test a popular narrative that cryptocurrency may serve as an alternative to precious metals as a store of value. With the exception of the exposure of Ethereum to gold, the exposures of all other cryptocurrencies to these commodities are not statistically significant.

Fourth, we study the exposure of cryptocurrency returns to macroeconomic factors. For Bitcoin and Ripple, the exposures to common macroeconomic factors (the non-durable consumption growth, durable consumption growth, industrial production growth, and personal income growth) are low and not statistically significant, while for Ethereum there is some loading on the durable consumption growth factor.

Summarizing, we established that the risk-return tradeoff of cryptocurrencies is distinct from those of stocks, currencies and precious metals. Hence, there is little evidence, in the view of the markets, behind the popular narratives that there are similarities between cryptocurrencies and these traditional assets.

We now turn to cryptocurrency specific factors. We formulate and investigate potential predictors for cryptocurrency returns that mirror those of traditional asset classes. Specifically, we construct cryptocurrency momentum, proxies for average and negative investor attention, a proxy for price-to-"dividend" ratio, ${ }^{2}$ realized volatility, and proxies for the supply conditions.

First, we show that there is significant time-series cryptocurrency momentum at the daily and weekly frequencies for all three cryptocurrencies. For example, a one-standard-deviation increase in the current day's Bitcoin return predicts a 0.33 percent increase in the daily return over the next day. Grouping weekly returns by quintiles, we find that the top quintiles outperform the bottom quintiles over the 1-4 week horizons. For example, at the 1-week horizon, the average return of the top quintile is 11.22 percent per week with the Sharpe ratio of 0.45 while the average return of the bottom quintile is 2.60 percent per week with the Sharpe ratio of 0.19. However, for Ethereum, the momentum effect is less significant than for Bitcoin and Ripple.

Second, we construct proxies for investor attention and show that high investor attention predicts high future returns over 1-2 week horizons for Bitcoin, a 1-week horizon for Ripple, and 1-, 3-, and 6-week horizons for Ethereum. For example, a one-standard-deviation increase in the Google search for the word "Bitcoin" yields a 2.3 percent increase in the 2 -week ahead Bitcoin returns. At the 1-week horizon, the average return of the top quintile is 11.20 percent per week with the Sharpe ratio of 0.48 while the average return of the bottom quintile is 1.07 percent per week with the Sharpe ratio of 0.08. Another proxy for investor attention we construct is Twitter post counts. A one-standard-deviation increase in the Twitter post count for the word "Bitcoin" yields a 2.50 percent increase in the 1-week ahead Bitcoin returns. Finally, we construct a proxy for negative investor attention and show that relatively high negative investor attention negatively predicts future Bitcoin returns. We construct a ratio between Google searches for the phrase "Bitcoin hack" and searches for the word "Bitcoin," and show that a one-standard-devation increase of the ratio leads to a 2.75 percent decrease in Bitcoin returns the following week.

Third, we construct a proxy for the the price-to-"dividend" ratios for Bitcoin and find that it has no predictive power. Realized volatility also does not predict returns of Bitcoin and Ethereum but predicts Ripple returns at 4-, 5-, and 7-day ahead frequencies.

Finally, we construct proxies for the cost of mining to capture the supply factors, and find that those have low loadings for Bitcoin and Ripple. For Ethereum, there is some evidence that returns are exposed to the stock returns of Advanced Micro Devices, Inc. (AMD), one of the main manufacturers of specialized mining hardware.

Our main conclusion is that indeed cryptocurrency represents an asset class that can be assessed using

\footnotetext{
${ }^{2}$ We use Bitcoin Wallet user count to measure the fundamental value of Bitcoin or "dividend."
} 
simple finance tools. At the same time, cryptocurrencies comprise an asset class which is radically different from traditional asset classes.

Our last group of results determines the exposures of various industries to cryptocurrencies. These results indicate which industries may benefit or may be disrupted by the blockchain technology. We start with 30 Fama French industries and find that Consumer Goods and Healthcare have significant and positive exposures to Bitcoin returns and that Fabricated Products and Metal Mining industries have significant and negative exposures to Bitcoin returns. Finance, Retail, and Wholesale industries have no exposure. We then estimate the exposures of 354 U.S. SIC 3-digit industries' on cryptocurrency returns and 137 Chinese CIC industries exposures on Bitcoin returns, controlling for the excess market returns, and create an index of industry exposures.

We now briefly discuss the relationship to the literature. Our paper uses standard textbook empirical asset pricing tools and methods, the discussion of which we mostly omit for conciseness. Our findings on momentum are related to a series of papers such as Jegadeesh and Titman (1993), Moskowitz and Grinblatt (1999). Moskowitz, Ooi, and Pedersen (2012), and Asness, Moskowitz, and Pedersen (2013). Da, Engelberg, and Gao (2011) uses Google searches to proxy for investor attention. Yermack (2015) is one of the first papers that brought academic attention to the field of cryptocurrency. Several recent papers (e.g., Stoffels, 2017, Borri, 2018, Borri and Shakhnov, 2018, Foley, Karlsen, and Putniňš (2018), and Hu, Parlour, and Rajan, 2018) document individual facts related to cryptocurrency investment. A number of recent papers develop models of cryptocurrencies (see, e.g., Weber (2016), Huberman, Leshno, and Moallemi (2017), Biais et al. (2018), Chiu and Koeppl (2017), Cong and He, 2018, Cong, Li, and Wang, 2018, Cong, He, and Li, 2018, Sockin and Xiong, 2018, Saleh, 2018, Schilling and Uhlig, 2018, Abadi and Brunnermeier (2018), Routledge and Zetlin-Jones (2018), and Makarov and Schoar (2018)).

\section{Data and Basic Characteristics}

Cryptocurrency price data series are from the CoinDesk (Bitcoin) and CoinMarketCap (Ripple and Ethereum) websites. For Bitcoin, we use data from 01/01/2011 to 05/31/2018 because there was not much liquidity and trading in earlier years. The data series for Ripple ranges from 08/04/2013 to 05/31/2018, and the data series for Ethereum ranges from 08/07/2015 to 05/31/2018. We construct cryptocurrency return data using the corresponding price data. Google search data series are downloaded from Google. Twitter post counts for the word "Bitcoin" are downloaded from Crimson Hexagon. ${ }^{3}$ The data series for the number of Bitcoin Wallet users is from blockchain.info. The Bitcoin price-to-"dividend" ratio is constructed from the ratio between Bitcoin price and the number of Bitcoin wallet users. The cryptocurrency realized volatility is measured as the sum of daily squared log returns from the previous month.

The spot exchange rates in units of US dollar per foreign currency are from the Federal Reserve Bank of St. Louis. We focus on five major currencies: Australian Dollar, Canadian Dollar, Euro, Singaporean Dollar, and UK Pound. The spot price of precious metals are from several sources. The gold and silver prices are from the London Bullion Market Association (LBMA). Platinum prices are from the London Platinum and Palladium Market (LPPM).

Aggregate and individual stock return data is from CRSP. Detailed SIC 3-digit industry return data series are constructed using individual stock returns. Chinese stock return data is from CSMAR. We construct the value-weighted aggregate Chinese stock returns and detailed CIC (China Industry Classification) industry

\footnotetext{
${ }^{3}$ We thank William Goetzmann for kindly sharing the Twitter post count data with us.
} 
return data series from the individual stocks. The data series of Chinese stock returns lasts until 2016/12.

Corporate bond return data series is constructed by Asvanunt and Richardson (2016) and is available on their website. ${ }^{4}$ For the housing market, we use the Case-Shiller housing index from Robert Shiller's website. The return series of the 155 anomalies are downloaded from Andrew Chen's website. ${ }^{5}$

We obtain the Fama French 3-factor, Carhart 4-factor, Fama French 5-factor, and Fama French 6-factor models dataseries from Kenneth French's website. We also obtain the return series of Fama French 30 industries, Europe, Japan, AsiaExJapan, and North America from Kenneth French's website.

The macroeconomic data series are from the website of the Federal Reserve Bank of St. Louis. Nondurable consumption is defined as the sum of personal consumption expenditures: non-durable goods, and personal consumption expenditures: services.

Stock market prices, dividends, and earnings, as well as the three-month Treasury bill rates, are from Robert Shiller's website. Using these data series, we construct the stock market price-to-dividend ratio (pd), price-to-earning ratio (pe), and the relative bill rate (tbill). The relative bill rate is defined as the threemonth Treasury bill rate minus its twelve-month backward moving average. Credit spread (credit) is defined as the yield spread between BAA corporate bonds and AAA corporate bonds. Term spread (term) is defined as the yield spread between the 10-year treasury and 3-month treasury. Data series on the BAA corporate yield, AAA corporate yield, 10-year treasury yield, and 3-month treasury yield are from the Federal Reserve Bank of St. Louis' website.

We now document main statistical properties of the time series for the returns of Bitcoin, Ripple, and Ethereum. Figure 1 plots the price movements for each of the three cryptocurrencies.

Figure 1: Price Movements

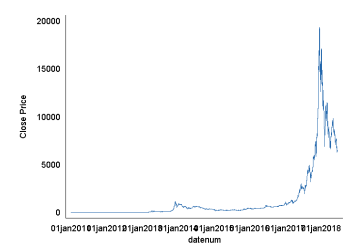

(a) Bitcoin

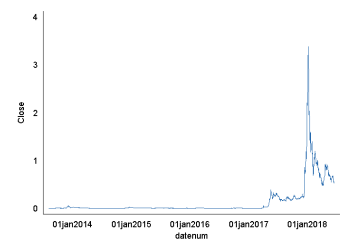

(b) Ripple

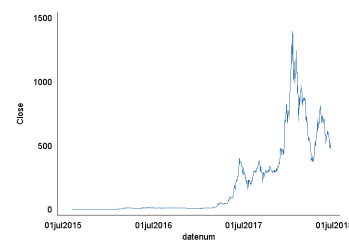

(c) Ethereum

Figure 2: Bitcoin Return Distributions
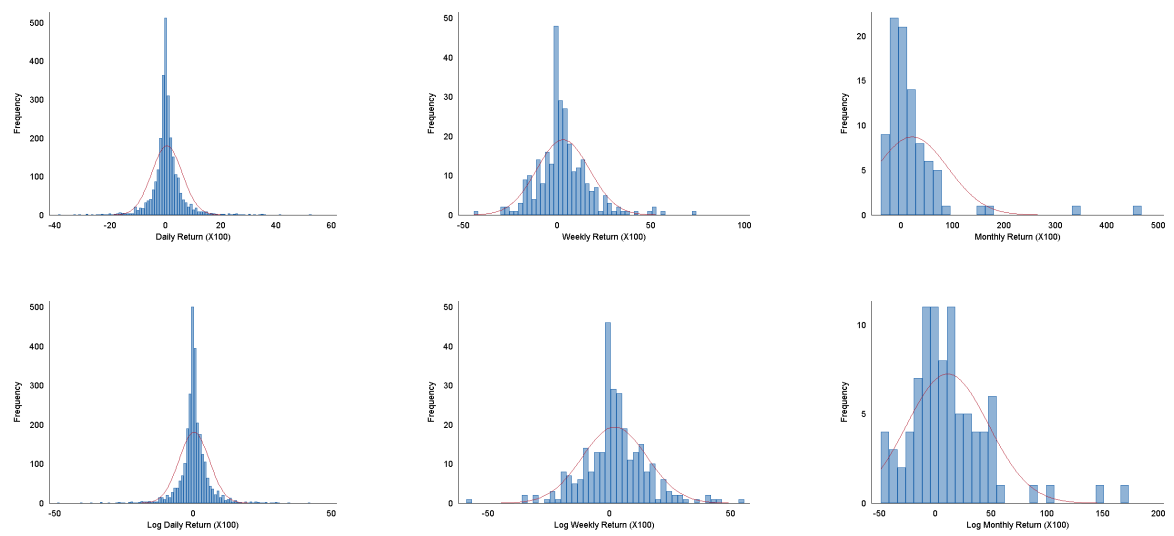

\footnotetext{
${ }^{4}$ https://www.aqr.com/Insights/Datasets/Credit-Risk-Premium-Preliminary-Paper-Data. The data series ends at 2014/12.

${ }^{5}$ One of the 156 anomalies does not exist during the sample period. The database ends at 2016/12.
} 
Figure 3: Ripple Return Distributions
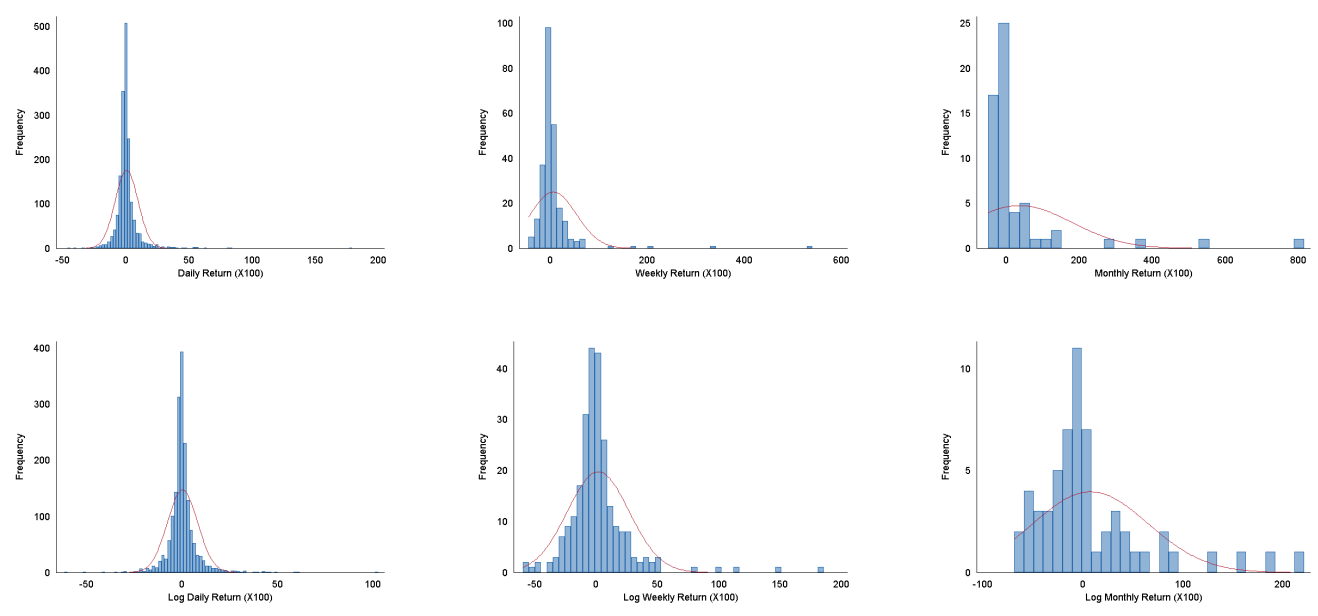

Figure 4: Ethereum Return Distributions
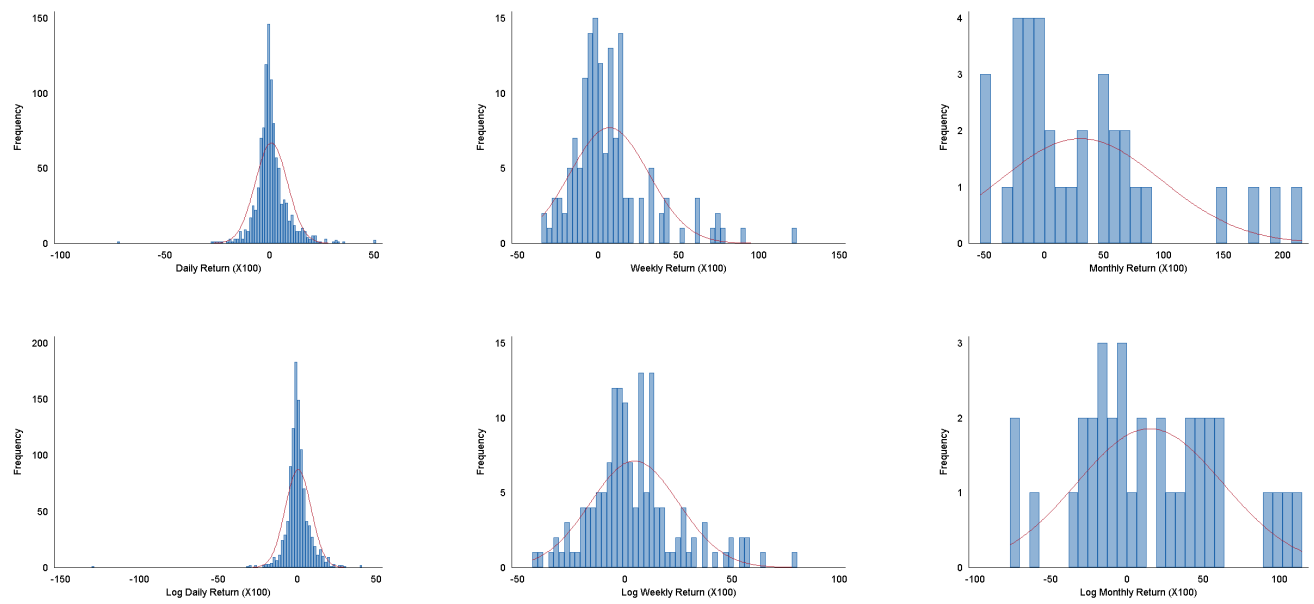

Table 1 and Figure 2 show the statistics of Bitcoin at the daily, weekly, and monthly frequencies compared to those of stocks, corporate bonds, and housing. Both the returns and their volatility are very high. At the daily frequency, the mean return is 0.52 percent and the standard deviation is 5.55 percent; at the weekly frequency, the mean return is 3.79 percent and the standard deviation is 16.64 percent; at the monthly frequency, the mean return is 21.60 percent and the standard deviation is 69.46 percent. Both the means and the standard deviations are an order of magnitude higher than those for traditional asset classes. These facts are broadly known.

The Sharpe ratios of bitcoin returns are 0.09 at the daily frequency, 0.23 at the weekly frequency, and 0.31 at the monthly frequency. At the monthly frequency, the Sharpe ratios are similar to those of stocks for the comparable time period, although higher than the historical Sharpe ratios for stocks. At the daily 
and weekly frequencies, the Sharpe ratios are about 50 percent and 75 percent higher than those of stocks for the comparable time period.

In Tables 2, and 3 and Figures 3 and 4, we document the main characteristics of the Ripple and Ethereum returns. Note that since the Ripple return series starts on 08/04/2013 and the Ethereum return series starts on $08 / 07 / 2015$, in the tables we present the statistics for Bitcoin for the corresponding periods. For the Ripple returns, the Sharpe ratios are 0.06 at the daily frequency, 0.13 at the weekly frequency, and 0.25 at the monthly frequency. The Ripple returns have a markedly higher mean and standard deviation compared to the Bitcoin returns of the period. However, during this period the Sharpe ratios of Ripple returns are comparable to the Sharpe ratios of Bitcoin returns. For Ethereum, the Sharpe ratios are 0.11 at the daily frequency, 0.28 at the weekly frequency, and 0.53 at the monthly frequency. The Ethereum returns also have higher mean and standard deviation than Bitcoin returns during the same period. However, during this period the Sharpe ratios of Ethereum returns are comparable to the Sharpe ratios of Bitcoin returns.

The Bitcoin returns are positively skewed at all frequencies in contrast to the stock returns which are negatively skewed. The skewness increases from 0.80 at the daily frequency to 1.76 at the weekly frequency, and to 4.32 at the monthly frequency. The corresponding kurtosis is 15.21 at the daily frequency, 10.25 at the weekly frequency, and 25.38 at the monthly frequency. The bitcoin returns have high probabilities of exceptional negative and positive daily returns. For example, the probability of a -20 percent daily return "disaster" is almost 0.5 percent; the probability of a 20 percent daily return "miracle" is almost 1 percent. The Ripple and Ethereum returns have similar characteristics: (1) positively skewed at all frequencies and having high kurtosis; and (2) high probabilities of exceptional negative and positive daily returns.

Table 1: Bitcoin Returns Summary Statistics and Comparison with Traditional Asset Classes

\begin{tabular}{|c|c|c|c|c|c|c|c|c|c|}
\hline \multicolumn{10}{|l|}{ Panel A } \\
\hline Daily & Mean & $\mathrm{SD}$ & T-Statistics & Sharpe & \multicolumn{2}{|c|}{ Skewness } & Kurtosis & $\%$ & Return $>0$ \\
\hline Bitcoin & $0.52 \%$ & $5.55 \%$ & 4.88 & 0.09 & \multicolumn{2}{|c|}{0.80} & 15.21 & & 53.69 \\
\hline Stock & $0.05 \%$ & $0.94 \%$ & 2.44 & 0.06 & \multicolumn{2}{|c|}{-0.51} & 7.95 & & 54.91 \\
\hline Stock* & $0.04 \%$ & $1.06 \%$ & 6.10 & 0.03 & \multicolumn{2}{|c|}{-0.13} & 19.72 & & 55.07 \\
\hline Weekly & Mean & $\mathrm{SD}$ & T-Statistics & Sharpe & \multicolumn{2}{|c|}{ Skewness } & Kurtosis & $\%$ & Return $>0$ \\
\hline Bitcoin & $3.79 \%$ & $16.64 \%$ & 4.49 & 0.23 & \multicolumn{2}{|c|}{1.76} & 10.25 & & 58.72 \\
\hline Stock & $0.26 \%$ & $1.93 \%$ & 2.59 & 0.13 & \multicolumn{2}{|c|}{-0.38} & 5.17 & & 59.95 \\
\hline Stock* & $0.21 \%$ & $2.45 \%$ & 6.02 & 0.06 & \multicolumn{2}{|c|}{-0.27} & 10.14 & & 58.40 \\
\hline Monthly & Mean & $\mathrm{SD}$ & T-Statistics & Sharpe & \multicolumn{2}{|c|}{ Skewness } & Kurtosis & & Return $>0$ \\
\hline Bitcoin & $21.60 \%$ & $69.46 \%$ & 2.95 & 0.31 & \multicolumn{2}{|c|}{4.32} & 25.38 & & 60.00 \\
\hline Stock & $1.08 \%$ & $3.24 \%$ & 3.12 & 0.33 & \multicolumn{2}{|c|}{-0.10} & 3.78 & & 68.89 \\
\hline Stock* & $0.91 \%$ & $4.27 \%$ & 5.36 & 0.12 & \multicolumn{2}{|c|}{-0.51} & 5.02 & & 62.16 \\
\hline Bond & $0.95 \%$ & $3.00 \%$ & 2.18 & 0.32 & \multicolumn{2}{|c|}{-0.10} & 2.73 & & 64.58 \\
\hline Housing & $0.40 \%$ & $0.72 \%$ & 5.15 & 0.55 & \multicolumn{2}{|c|}{-0.01} & 3.17 & & 73.56 \\
\hline \multicolumn{10}{|c|}{ Note: Stock* shows results for the whole sample between $1953 / 07$ and $2018 / 04$. } \\
\hline & \multicolumn{9}{|c|}{ Panel B: Extreme Events of Daily Bitcoin Returns } \\
\hline & Disasters & Counts & Percentage & \multicolumn{3}{|c|}{ Miracles Counts } & \multicolumn{3}{|c|}{ Percentage } \\
\hline & $<-5 \%$ & 225 & $8.26 \%$ & \multicolumn{3}{|c|}{$>5 \% \quad 304$} & \multicolumn{2}{|c|}{$11.16 \%$} & \\
\hline & $<-10 \%$ & 78 & $2.86 \%$ & \multicolumn{2}{|c|}{$>10 \%$} & 104 & \multicolumn{2}{|c|}{$3.82 \%$} & \\
\hline & $<-20 \%$ & 13 & $0.48 \%$ & \multicolumn{2}{|c|}{$>20 \%$} & 26 & \multicolumn{2}{|c|}{$0.95 \%$} & \\
\hline & $<-30 \%$ & 3 & $0.11 \%$ & \multicolumn{2}{|c|}{$>30 \%$} & 9 & \multicolumn{2}{|c|}{$0.33 \%$} & \\
\hline
\end{tabular}


Table 2: Ripple Returns Summary Statistics

\begin{tabular}{|c|c|c|c|c|c|c|c|c|c|}
\hline \multicolumn{10}{|c|}{ Panel A: Return Summary } \\
\hline \multicolumn{10}{|c|}{ Ripple Returns } \\
\hline & Mean & $\mathrm{SD}$ & T-Statistics & Sharpe & \multicolumn{2}{|c|}{ Skewness } & Kurtosis & $\%$ & Return $>0$ \\
\hline Daily & $0.59 \%$ & $9.11 \%$ & 2.74 & 0.06 & \multicolumn{2}{|c|}{6.11} & 99.05 & & 46.09 \\
\hline Weekly & $6.26 \%$ & $47.39 \%$ & 2.11 & 0.13 & \multicolumn{2}{|c|}{7.62} & 76.26 & & 46.27 \\
\hline Monthly & $36.20 \%$ & $143.31 \%$ & 1.94 & 0.25 & \multicolumn{2}{|c|}{3.82} & 18.69 & & 40.68 \\
\hline \multicolumn{10}{|c|}{ Same Period Bitcoin Returns } \\
\hline & Mean & $\mathrm{SD}$ & T-Statistics & Sharpe & \multicolumn{2}{|c|}{ Skewness } & Kurtosis & & Return $>0$ \\
\hline Daily & $0.34 \%$ & $4.47 \%$ & 3.17 & 0.08 & \multicolumn{2}{|c|}{0.54} & 13.08 & & 54.58 \\
\hline Weekly & $2.42 \%$ & $12.68 \%$ & 3.04 & 0.19 & \multicolumn{2}{|c|}{0.88} & 5.72 & & 56.86 \\
\hline \multirow[t]{7}{*}{ Monthly } & $14.93 \%$ & $64.87 \%$ & 1.77 & 0.23 & \multicolumn{2}{|c|}{5.88} & 41.58 & & 55.93 \\
\hline & \multicolumn{9}{|c|}{ Panel B: Extreme Events of Daily Ripple Returns } \\
\hline & Disasters & Counts & Percentage & \multicolumn{3}{|c|}{ Miracles } & \multicolumn{2}{|c|}{ Percentage } & \\
\hline & $<-5 \%$ & 224 & $12.59 \%$ & $>5$ & & 247 & 13.88 & & \\
\hline & $<-10 \%$ & 75 & $4.22 \%$ & $>10$ & & 119 & 6.69 & & \\
\hline & $<-20 \%$ & 11 & $0.62 \%$ & $>20$ & & 44 & 2.47 & & \\
\hline & $<-30 \%$ & 3 & $0.17 \%$ & $>30$ & & 21 & 1.18 & & \\
\hline
\end{tabular}

Table 3: Ethereum Returns Summary Statistics

\begin{tabular}{|c|c|c|c|c|c|c|c|c|}
\hline \multicolumn{9}{|c|}{ Panel A: Returns Summary Statistics } \\
\hline \multicolumn{9}{|c|}{ Ethereum Returns } \\
\hline & Mean & SD & T-Statistics & Sharpe & \multicolumn{2}{|c|}{ Skewness } & Kurtosis & $\%$ Return $>0$ \\
\hline Daily & $0.81 \%$ & $7.71 \%$ & 3.41 & 0.11 & \multicolumn{2}{|c|}{0.24} & 15.71 & 49.33 \\
\hline Weekly & $6.88 \%$ & $24.51 \%$ & 3.43 & 0.28 & \multicolumn{2}{|c|}{1.71} & 7.24 & 54.00 \\
\hline Monthly & $30.26 \%$ & $67.56 \%$ & 2.65 & 0.53 & \multicolumn{2}{|c|}{1.24} & 3.95 & 54.29 \\
\hline \multicolumn{9}{|c|}{ Same Period Bitcoin Return } \\
\hline & Mean & $\mathrm{SD}$ & T-Statistics & Sharpe & \multicolumn{2}{|c|}{ Skewness } & Kurtosis & $\%$ Return $>0$ \\
\hline Daily & $0.38 \%$ & $4.07 \%$ & 3.04 & 0.09 & \multicolumn{2}{|c|}{0.19} & 7.54 & 56.88 \\
\hline Weekly & $2.84 \%$ & $11.80 \%$ & 2.94 & 0.24 & \multicolumn{2}{|c|}{0.26} & 4.05 & 62.00 \\
\hline \multirow[t]{7}{*}{ Monthly } & $12.05 \%$ & $25.10 \%$ & 2.84 & 0.48 & \multicolumn{2}{|c|}{0.51} & 2.88 & 65.71 \\
\hline & \multicolumn{8}{|c|}{ Panel B: Extreme Events of Daily Ethereum Returns } \\
\hline & Disasters & Counts & Percentage & Mira & cles & Counts & Percer & age \\
\hline & $<-5 \%$ & 134 & $12.81 \%$ & $>5$ & & 198 & 18.9 & \\
\hline & $<-10 \%$ & 39 & $3.73 \%$ & $>1$ & & 96 & 9.20 & \\
\hline & $<-20 \%$ & 6 & $0.57 \%$ & $>2$ & & 23 & 2.20 & \\
\hline & $<-30 \%$ & 1 & $0.10 \%$ & $>30$ & & 8 & 0.76 & \\
\hline
\end{tabular}


Table 4: Return Summary Statistics by Day of the Week

\begin{tabular}{lcccclcccc}
\hline Bitcoin & Mean & SD & T-Statistics & Sharpe & Ripple & Mean & SD & T-Statistics & Sharpe \\
\hline Monday & $0.67 \%$ & $5.48 \%$ & 2.43 & 0.12 & Monday & $0.05 \%$ & $7.70 \%$ & 0.11 & 0.01 \\
Tuesday & $1.01 \%$ & $6.09 \%$ & 3.25 & 0.17 & Tuesday & $0.75 \%$ & $9.04 \%$ & 1.32 & 0.08 \\
Wednesday & $0.46 \%$ & $5.62 \%$ & 1.62 & 0.08 & Wednesday & $0.45 \%$ & $6.86 \%$ & 1.03 & 0.06 \\
Thursday & $0.66 \%$ & $5.95 \%$ & 2.18 & 0.11 & Thursday & $1.45 \%$ & $10.90 \%$ & 2.13 & 0.13 \\
Friday & $0.32 \%$ & $5.71 \%$ & 1.09 & 0.06 & Friday & $0.97 \%$ & $7.71 \%$ & 2.01 & 0.13 \\
Saturday & $0.33 \%$ & $5.32 \%$ & 1.24 & 0.06 & Saturday & $-0.14 \%$ & $7.32 \%$ & -0.29 & -0.02 \\
Sunday & $0.18 \%$ & $4.52 \%$ & 0.80 & 0.04 & Sunday & $0.61 \%$ & $12.72 \%$ & 0.76 & 0.05 \\
\hline Ethereum & Mean & SD & T-Statistics & Sharpe & Stock & Mean & SD & T-Statistics & Sharpe \\
\hline Monday & $0.38 \%$ & $7.39 \%$ & 0.62 & 0.05 & Monday & $-0.03 \%$ & $1.00 \%$ & -0.47 & -0.03 \\
Tuesday & $1.53 \%$ & $8.86 \%$ & 2.11 & 0.17 & Tuesday & $0.12 \%$ & $0.90 \%$ & 2.55 & 0.13 \\
Wednesday & $0.86 \%$ & $6.83 \%$ & 1.53 & 0.13 & Wednesday & $0.04 \%$ & $0.93 \%$ & 0.94 & 0.05 \\
Thursday & $1.72 \%$ & $8.72 \%$ & 2.41 & 0.20 & Thursday & $0.06 \%$ & $0.97 \%$ & 1.23 & 0.06 \\
Friday & $0.21 \%$ & $6.75 \%$ & 0.39 & 0.03 & Friday & $0.06 \%$ & $0.88 \%$ & 1.31 & 0.07 \\
Saturday & $0.26 \%$ & $8.83 \%$ & 0.36 & 0.03 & & & & & \\
Sunday & $0.74 \%$ & $6.15 \%$ & 1.47 & 0.12 & & & & & \\
\hline
\end{tabular}

Table 4 shows the mean, standard deviation, and Sharpe ratios of the returns on different days of the week. In contrast to the stocks, there is no pronounced Monday effect. However, the returns are lower on Saturdays: Bitcoin -0.33 percent with the Sharpe ratio of 0.06 compared to 0.52 percent daily average with the Sharpe ratio of 0.09; Ripple - -0.14 percent with the Sharpe ratio of -0.02 compared to 0.59 percent daily average with the Sharpe ratio of 0.06 ; and Ethereum -0.26 percent with the Sharpe ratio of 0.03 compared to 0.81 percent daily average with the Sharpe ratio of 0.03 . While Bitcoin returns are somewhat lower on Sundays, the returns on Saturday is consistently lower across all three cryptocurrencies.

In this paper, we report two types of t-statistics: (1) based on regular standard error, and (2) based on bootstrapped standard error. The first type is reported in parentheses and the second type is reported in brackets.

\section{$3 \quad$ Risk Exposures}

In this section, we establish facts on factor loadings and on exposures to stocks, currencies, and precious metals commodities. Throughout this section, t-statistics in parentheses and brackets are based on regular and bootstrapped standard errors.

\subsection{Stock Factors Loadings}

Table 5 documents the common stock factor exposures of the Bitcoin returns. For the risk factors, we choose the CAPM, Fama French 3-factor, Carhart 4-factor, Fama French 5-factor, and Fama French 6-factor models. The alphas for all of the considered models are statistically significant. The unconditional alpha of the period is 22.45 percent per month. The CAPM adjusted alpha decreases to 18.91 percent per month - a reduction of about 16 percent. The CAPM beta is large at 3.34 but not statistically significant. The beta is statistically significant at the 10-percent level only for the 5 -factor and 6 -factor models. The corresponding alphas are 16.72 and 15.98 percent per month. The exposures to the other factors are not statistically significant. The exposures to the SMB factor is not stable across the specifications: both the magnitude 
and the signs change when 5-factor and 6-factor models are considered. The exposures to the HML factor are negative and have consistent magnitudes and signs; this suggests that Bitcoin returns may comove more with growth rather than with value firms. The exposures to the RMW factor are positive and are estimated slightly more accurately than other statistically not significant factors; this suggests that Bitcoin returns comove more with high profit rather than low profit firms. The point estimates on the MOM and CMA factors are very inaccurate. ${ }^{6}$

Table 5: Bitcoin Returns Factor Loadings

\begin{tabular}{|c|c|c|c|c|c|}
\hline (Percentage) & CAPM & 3-Fac & 4-Fac & 5-Fac & 6-Fac \\
\hline \multirow[t]{3}{*}{ ALPHA } & $18.91^{* *}$ & $18.20^{* *}$ & $17.66^{* *}$ & $16.72^{* *}$ & $15.98^{*}$ \\
\hline & $(2.42)$ & $(2.30)$ & $(2.18)$ & $(2.07)$ & $(1.94)$ \\
\hline & {$[2.55]$} & {$[2.34]$} & {$[2.28]$} & {$[2.61]$} & {$[2.54]$} \\
\hline \multirow[t]{3}{*}{ MKTRF } & 3.34 & 3.79 & 4.00 & $4.57^{*}$ & $4.85^{*}$ \\
\hline & $(1.45)$ & $(1.56)$ & $(1.60)$ & $(1.81)$ & $(1.86)$ \\
\hline & [1.94] & {$[2.08]$} & {$[1.94]$} & {$[2.14]$} & {$[2.06]$} \\
\hline \multirow[t]{3}{*}{ SMB } & & -1.29 & -1.26 & 0.45 & 0.55 \\
\hline & & $(-0.36)$ & $(-0.35)$ & $(0.12)$ & $(0.14)$ \\
\hline & & {$[-0.55]$} & {$[-0.54]$} & {$[0.15]$} & {$[0.16]$} \\
\hline \multirow[t]{3}{*}{ HML } & & -3.02 & -2.41 & -3.80 & -3.01 \\
\hline & & $(-0.81)$ & $(-0.59)$ & $(-0.79)$ & $(-0.58)$ \\
\hline & & {$[-1.22]$} & {$[-0.84]$} & {$[-0.97]$} & {$[-0.67]$} \\
\hline \multirow[t]{3}{*}{ MOM } & & & 1.08 & & 1.35 \\
\hline & & & $(0.38)$ & & $(0.47)$ \\
\hline & & & {$[0.48]$} & & {$[0.59]$} \\
\hline \multirow[t]{3}{*}{ RMW } & & & & 6.16 & 6.39 \\
\hline & & & & $(1.07)$ & $(1.10)$ \\
\hline & & & & {$[1.35]$} & {$[1.41]$} \\
\hline \multirow[t]{3}{*}{ CMA } & & & & 2.47 & 2.40 \\
\hline & & & & $(0.35)$ & $(0.33)$ \\
\hline & & & & {$[0.27]$} & {$[0.24]$} \\
\hline R-Squared & 0.02 & 0.04 & 0.04 & 0.05 & 0.05 \\
\hline
\end{tabular}

Table 6 documents the common stock factor exposures of the Ripple returns and compares them to the Bitcoin returns for the same time period. The Bitcoin returns for this time period have similar risk exposures as those in the full sample but have smaller and mostly insignificant alphas. We now turn to the analysis of Ripple. The alphas for all of the considered models are statistically significant. The unconditional alpha of the period is 38.15 percent per month and is more than twice as large as that for Bitcoin. The CAPM adjusted alpha is about the same as the unadjusted alpha. The CAPM beta is about half the size of Bitcoin and is not significant. In contrast to Bitcoin, there are statistically significant large negative loadings on the HML factor within the 5-factor and 6-factor models. The exposures to the other factors are not statistically significant. Summarizing, Ripple has performed better than Bitcoin for the corresponding time period, and its returns comove with growth rather than value firms.

\footnotetext{
${ }^{6}$ Stoffels (2017) and Gilbert and Loi (2018) examine cryptocurrency loadings on the CAPM and Fama French 3-factor models.
} 
Table 6: Ripple Return Factor Loadings

\begin{tabular}{|c|c|c|c|c|c|}
\hline \multirow[b]{2}{*}{ (Percentage) } & \multicolumn{5}{|c|}{ Ripple Return } \\
\hline & CAPM & 3-Fac & 4-Fac & 5-Fac & $6-\mathrm{Fac}$ \\
\hline \multirow[t]{3}{*}{ ALPHA } & $36.61^{*}$ & $35.30^{*}$ & $38.46^{*}$ & $39.92^{*}$ & $41.33^{*}$ \\
\hline & $(1.78)$ & $(1.70)$ & $(1.82)$ & $(1.90)$ & $(1.93)$ \\
\hline & {$[2.43]$} & {$[2.24]$} & {$[2.18]$} & {$[2.06]$} & {$[1.97]$} \\
\hline \multirow[t]{3}{*}{ MKTRF } & 1.56 & 1.59 & -0.06 & 2.73 & 1.81 \\
\hline & $(0.23)$ & $(0.23)$ & $(-0.01)$ & $(0.40)$ & $(0.25)$ \\
\hline & {$[0.45]$} & {$[0.42]$} & {$[-0.01]$} & {$[0.70]$} & {$[0.43]$} \\
\hline \multirow[t]{3}{*}{ SMB } & & 0.82 & 0.57 & 2.95 & 2.57 \\
\hline & & $(0.10)$ & $(0.07)$ & $(0.32)$ & $(0.27)$ \\
\hline & & {$[0.15]$} & {$[0.10]$} & {$[0.42]$} & {$[0.33]$} \\
\hline \multirow[t]{3}{*}{ HML } & & -8.88 & -13.48 & $-22.27^{*}$ & $-23.80^{*}$ \\
\hline & & $(-1.01)$ & $(-1.33)$ & $(-1.94)$ & $(-1.98)$ \\
\hline & & {$[-1.99]$} & {$[-2.02]$} & {$[-2.10]$} & {$[-2.03]$} \\
\hline \multirow[t]{3}{*}{ MOM } & & & -6.88 & & -3.54 \\
\hline & & & $(-0.92)$ & & $(-0.46)$ \\
\hline & & & {$[-1.08]$} & & {$[-0.59]$} \\
\hline \multirow[t]{3}{*}{ RMW } & & & & 6.90 & 6.10 \\
\hline & & & & $(0.47)$ & $(0.41)$ \\
\hline & & & & {$[0.78]$} & {$[0.67]$} \\
\hline \multirow[t]{3}{*}{ CMA } & & & & 30.92 & 29.05 \\
\hline & & & & $(1.67)$ & $(1.52)$ \\
\hline & & & & {$[1.29]$} & {$[1.24]$} \\
\hline \multirow[t]{2}{*}{ R-Squared } & 0.00 & 0.02 & 0.04 & 0.08 & 0.09 \\
\hline & \multicolumn{5}{|c|}{ Same Period Bitcoin Return } \\
\hline (Percentage) & CAPM & 3-Fac & 4-Fac & 5 -Fac & $6-\mathrm{Fac}$ \\
\hline \multirow[t]{3}{*}{ ALPHA } & 12.72 & 12.49 & 11.87 & 11.43 & 10.75 \\
\hline & (1.39) & $(1.33)$ & $(1.24)$ & $(1.17)$ & $(1.08)$ \\
\hline & {$[2.03]$} & {$[1.81]$} & {$[1.85]$} & {$[1.64]$} & {$[1.69]$} \\
\hline \multirow[t]{3}{*}{ MKTRF } & 3.30 & 3.37 & 3.69 & 3.27 & 3.71 \\
\hline & $(1.10)$ & $(1.09)$ & $(1.14)$ & $(1.03)$ & $(1.12)$ \\
\hline & {$[1.28]$} & [1.35] & {$[1.31]$} & {$[1.26]$} & {$[1.23]$} \\
\hline \multirow[t]{3}{*}{ SMB } & & -0.43 & -0.38 & 1.05 & 1.23 \\
\hline & & $(-0.12)$ & $(-0.10)$ & $(0.24)$ & $(0.28)$ \\
\hline & & {$[-0.20]$} & {$[-0.18]$} & {$[0.32]$} & {$[0.37]$} \\
\hline \multirow[t]{3}{*}{ HML } & & -0.86 & 0.03 & -0.64 & 0.10 \\
\hline & & $(-0.22)$ & $(0.01)$ & $(-0.12)$ & $(0.02)$ \\
\hline & & {$[-0.59]$} & {$[0.00]$} & {$[-0.37]$} & {$[0.05]$} \\
\hline \multirow[t]{3}{*}{ MOM } & & & 1.33 & & 1.71 \\
\hline & & & $(0.39)$ & & $(0.48)$ \\
\hline & & & {$[0.78]$} & & {$[0.84]$} \\
\hline \multirow[t]{3}{*}{ RMW } & & & & 4.77 & 5.15 \\
\hline & & & & $(0.71)$ & $(0.75)$ \\
\hline & & & & {$[1.21]$} & {$[1.21]$} \\
\hline \multirow[t]{3}{*}{ CMA } & & & & -1.46 & -0.55 \\
\hline & & & & $(-0.17)$ & $(-0.06)$ \\
\hline & & & & {$[-0.50]$} & {$[-0.18]$} \\
\hline R-Squared & 0.02 & 0.02 & 0.03 & 0.03 & 0.04 \\
\hline
\end{tabular}


Table 7: Ethereum Return Factor Loadings

\begin{tabular}{|c|c|c|c|c|c|}
\hline \multirow[b]{2}{*}{ (Percentage) } & \multicolumn{5}{|c|}{ Ethereum Return } \\
\hline & CAPM & $3-\mathrm{Fac}$ & $4-\mathrm{Fac}$ & 5 -Fac & 6 -Fac \\
\hline \multirow[t]{3}{*}{ ALPHA } & $31.42^{* *}$ & $33.04^{* * *}$ & $35.69^{* * *}$ & $31.55^{* * *}$ & $33.28^{* * *}$ \\
\hline & $(2.49)$ & $(2.82)$ & $(3.19)$ & $(2.80)$ & $(2.99)$ \\
\hline & {$[2.54]$} & {$[2.93]$} & {$[2.93]$} & {$[2.57]$} & {$[2.70]$} \\
\hline \multirow[t]{3}{*}{ MKTRF } & 1.61 & 2.04 & -0.86 & 2.86 & 0.50 \\
\hline & $(0.41)$ & $(0.55)$ & $(-0.23)$ & $(0.81)$ & $(0.13)$ \\
\hline & {$[0.44]$} & {$[0.62]$} & {$[-0.19]$} & {$[0.85]$} & {$[0.11]$} \\
\hline \multirow[t]{3}{*}{ SMB } & & -3.47 & -6.71 & -1.35 & -3.66 \\
\hline & & $(-0.69)$ & $(-1.33)$ & $(-0.26)$ & $(-0.68)$ \\
\hline & & {$[-0.58]$} & {$[-1.35]$} & {$[-0.21]$} & {$[-0.62]$} \\
\hline \multirow[t]{3}{*}{ HML } & & $-10.25^{* *}$ & $-13.65^{* *}$ & $-15.15^{* *}$ & $-16.05^{* * *}$ \\
\hline & & $(-2.07)$ & $(-2.74)$ & $(-2.69)$ & $(-2.89)$ \\
\hline & & {$[-1.66]$} & {$[-1.83]$} & {$[-2.10]$} & {$[-2.38]$} \\
\hline \multirow[t]{3}{*}{ MOM } & & & $-9.46^{* *}$ & & -6.77 \\
\hline & & & $(-2.06)$ & & $(-1.41)$ \\
\hline & & & {$[-2.02]$} & & {$[-1.30]$} \\
\hline \multirow[t]{3}{*}{ RMW } & & & & 11.46 & 10.41 \\
\hline & & & & $(1.50)$ & $(1.38)$ \\
\hline & & & & {$[1.57]$} & {$[1.35]$} \\
\hline \multirow[t]{3}{*}{ CMA } & & & & 13.62 & 9.43 \\
\hline & & & & $(1.60)$ & $(1.06)$ \\
\hline & & & & {$[1.51]$} & {$[1.14]$} \\
\hline \multirow[t]{2}{*}{ R-Squared } & 0.01 & 0.21 & 0.31 & 0.34 & 0.39 \\
\hline & \multicolumn{5}{|c|}{ Same Period Bitcoin Return } \\
\hline (Percentage $)$ & CAPM & 3-Fac & 4-Fac & 5 -Fac & $6-\mathrm{Fac}$ \\
\hline \multirow[t]{3}{*}{ ALPHA } & $12.25^{* *}$ & $12.26^{* * *}$ & $11.87^{* *}$ & $11.67^{* *}$ & $11.32^{* *}$ \\
\hline & $(2.73)$ & $(2.84)$ & $(2.72)$ & $(2.59)$ & $(2.47)$ \\
\hline & {$[2.99]$} & {$[2.98]$} & {$[3.01]$} & {$[2.81]$} & {$[2.85]$} \\
\hline \multirow[t]{3}{*}{ MKTRF } & 1.61 & 2.01 & 2.44 & 1.85 & 2.34 \\
\hline & $(1.15)$ & $(1.47)$ & $(1.65)$ & $(1.30)$ & $(1.47)$ \\
\hline & {$[1.35]$} & {$[1.43]$} & {$[1.25]$} & {$[1.29]$} & {$[1.09]$} \\
\hline \multirow[t]{3}{*}{ SMB } & & -2.94 & -2.45 & -2.38 & -1.91 \\
\hline & & $(-1.59)$ & $(-1.25)$ & $(-1.14)$ & $(-0.86)$ \\
\hline & & {$[-1.55]$} & {$[-1.59]$} & {$[-0.95]$} & {$[-0.88]$} \\
\hline \multirow[t]{3}{*}{ HML } & & -1.28 & -0.77 & -0.58 & -0.39 \\
\hline & & $(-0.70)$ & $(-0.40)$ & $(-0.26)$ & $(-0.17)$ \\
\hline & & {$[-0.70]$} & {$[-0.34]$} & {$[-0.26]$} & {$[-0.15]$} \\
\hline \multirow[t]{3}{*}{ MOM } & & & 1.42 & & 1.39 \\
\hline & & & $(0.79)$ & & $(0.70)$ \\
\hline & & & {$[0.64]$} & & {$[0.58]$} \\
\hline \multirow[t]{3}{*}{ RMW } & & & & 1.61 & 1.82 \\
\hline & & & & $(0.52)$ & $(0.58)$ \\
\hline & & & & {$[0.54]$} & {$[0.60]$} \\
\hline \multirow[t]{3}{*}{ CMA } & & & & -1.88 & -1.02 \\
\hline & & & & $(-0.55)$ & $(-0.28)$ \\
\hline & & & & {$[-0.53]$} & {$[-0.31]$} \\
\hline R-Squared & 0.04 & 0.18 & 0.20 & 0.19 & 0.21 \\
\hline
\end{tabular}

Table 7 documents the common stock factor exposures of the Ethereum returns and compares them to the 
Bitcoin returns for the same time period. The Bitcoin returns for this time period have a smaller exposure to the market and also have smaller alphas compared to the full sample. We now turn to the analysis of Ethereum. The alphas for all the considered models are statistically significant. The unconditional alpha of the period is 32.87 percent per month, comparable to Ripple and more than two times larger than that of Bitcoin. The CAPM adjusted alpha is about the same as the unadjusted alpha. The CAPM beta is about the same size as Bitcoin and is not significant. In contrast to Bitcoin, there is significant large negative loadings on the HML factor for 3-factor, 4-factor, 5-factor and 6-factor models. The exposures to the other factors are not statistically significant. Summarizing, Ethereum has performed better than Bitcoin for the corresponding time period, and its returns comove with the growth rather than the value firms for all of the specifications of the multi-factor models.

\subsection{Currency}

Table 8 shows currency exposures of Bitcoin, Ripple, and Ethereum returns. For currency returns, we consider five major currencies: Australian Dollar, Canadian Dollar, Euro, Singaporean Dollar, and UK Pound. The exposures of all other cryptocurrencies to these commodities are not statistically significant and the alpha estimates barely change. In Table 9, we investigate the currency exposures of Bitcoin returns over shorter periods corresponding to those of Ripple and Ethereum. Again, the currency exposures of Bitcoin returns over the shorter periods are small and statistically insignificant. We conclude that there is no consistent evidence of systematic currency exposures in cryptocurrencies.

Table 8: Currency Loadings of Cryptocurrency Returns

\begin{tabular}{|c|c|c|c|c|c|}
\hline Panel A: Bitcoin & (1) & (2) & (3) & (4) & (5) \\
\hline \multirow[t]{3}{*}{ APLHA } & $22.92^{* * *}$ & $23.11^{* * * *}$ & $22.70^{\text {**** }}$ & $22.58^{* * * *}$ & $22.83^{* * *}$ \\
\hline & $(3.05)$ & $(3.05)$ & $(3.04)$ & $(3.02)$ & $(3.06)$ \\
\hline & {$[3.07]$} & {$[3.16]$} & [3.23] & {$[3.16]$} & {$[3.22]$} \\
\hline \multirow[t]{3}{*}{ AUSTRALIA } & 1.56 & & & & \\
\hline & $(0.66)$ & & & & \\
\hline & {$[0.46]$} & & & & \\
\hline \multirow[t]{3}{*}{ CANADA } & & 2.47 & & & \\
\hline & & $(0.59)$ & & & \\
\hline & & {$[0.64]$} & & & \\
\hline \multirow[t]{3}{*}{ EURO } & & & 2.72 & & \\
\hline & & & $(0.89)$ & & \\
\hline & & & {$[0.83]$} & & \\
\hline \multirow[t]{3}{*}{ SINGAPORE } & & & & 3.73 & \\
\hline & & & & $(0.86)$ & \\
\hline & & & & {$[0.67]$} & \\
\hline \multirow[t]{3}{*}{ UK } & & & & & 3.35 \\
\hline & & & & & $(1.10)$ \\
\hline & & & & & {$[0.97]$} \\
\hline R-Squared & 0.01 & 0.00 & 0.01 & 0.01 & 0.01 \\
\hline
\end{tabular}




\begin{tabular}{|c|c|c|c|c|c|}
\hline Panel B: Ripple & $(1)$ & $(2)$ & $(3)$ & $(4)$ & $(5)$ \\
\hline \multirow[t]{3}{*}{ APLHA } & $38.38^{*}$ & $36.46^{*}$ & $40.54^{* *}$ & $38.54^{*}$ & $39.11^{* *}$ \\
\hline & $(1.96)$ & $(1.85)$ & $(2.11)$ & $(1.98)$ & $(2.01)$ \\
\hline & {$[2.35]$} & {$[2.45]$} & {$[2.63]$} & {$[2.48]$} & {$[2.51]$} \\
\hline \multirow[t]{3}{*}{ AUSTRALIA } & 0.62 & & & & \\
\hline & $(0.09)$ & & & & \\
\hline & {$[0.07]$} & & & & \\
\hline \multirow[t]{3}{*}{ CANADA } & & -4.69 & & & \\
\hline & & $(-0.48)$ & & & \\
\hline & & {$[-0.88]$} & & & \\
\hline \multirow[t]{3}{*}{ EURO } & & & 10.90 & & \\
\hline & & & $(1.28)$ & & \\
\hline & & & {$[2.07]$} & & \\
\hline \multirow[t]{3}{*}{ SINGAPORE } & & & & 3.69 & \\
\hline & & & & $(0.27)$ & \\
\hline & & & & {$[0.32]$} & \\
\hline \multirow[t]{3}{*}{ UK } & & & & & 4.13 \\
\hline & & & & & $(0.55)$ \\
\hline & & & & & [1.18] \\
\hline R-Squared & 0.00 & 0.00 & 0.03 & 0.00 & 0.01 \\
\hline Panel C: Ethereum & $(1)$ & $(2)$ & (3) & $(4)$ & $(5)$ \\
\hline \multirow[t]{3}{*}{ APLHA } & $32.86^{* *}$ & $32.87^{* *}$ & $31.34^{* *}$ & $32.34^{* * *}$ & $33.36^{* *}$ \\
\hline & $(2.71)$ & $(2.70)$ & $(2.63)$ & $(2.77)$ & $(2.71)$ \\
\hline & {$[2.75]$} & {$[2.88]$} & {$[2.69]$} & {$[2.76]$} & {$[2.71]$} \\
\hline \multirow[t]{3}{*}{ AUSTRALIA } & 1.77 & & & & \\
\hline & $(0.39)$ & & & & \\
\hline & {$[0.52]$} & & & & \\
\hline \multirow[t]{3}{*}{ CANADA } & & -0.07 & & & \\
\hline & & $(-0.01)$ & & & \\
\hline & & {$[-0.01]$} & & & \\
\hline \multirow[t]{3}{*}{ EURO } & & & 7.35 & & \\
\hline & & & $(1.29)$ & & \\
\hline & & & {$[1.40]$} & & \\
\hline \multirow[t]{3}{*}{ SINGAPORE } & & & & 12.32 & \\
\hline & & & & $(1.63)$ & \\
\hline & & & & {$[1.80]$} & \\
\hline \multirow[t]{3}{*}{ UK } & & & & & 1.02 \\
\hline & & & & & $(0.24)$ \\
\hline & & & & & {$[0.25]$} \\
\hline R-Squared & 0.00 & 0.00 & 0.05 & 0.08 & 0.00 \\
\hline
\end{tabular}


Table 9: Currency Loadings of Bitcoin Returns - Different Period

\begin{tabular}{|c|c|c|c|c|c|}
\hline Panel A: Ripple Period & $(1)$ & $(2)$ & (3) & (4) & $(5)$ \\
\hline \multirow[t]{3}{*}{ APLHA } & $14.91^{*}$ & $15.93^{*}$ & $16.25^{*}$ & $15.76^{*}$ & $16.29^{*}$ \\
\hline & $(1.70)$ & $(1.78)$ & $(1.84)$ & $(1.79)$ & $(1.85)$ \\
\hline & {$[2.21]$} & {$[2.15]$} & {$[1.98]$} & {$[2.07]$} & {$[1.85]$} \\
\hline \multirow[t]{3}{*}{ AUSTRALIA } & -2.90 & & & & \\
\hline & $(-0.93)$ & & & & \\
\hline & {$[-0.77]$} & & & & \\
\hline \multirow[t]{3}{*}{ CANADA } & & -0.11 & & & \\
\hline & & $(-0.02)$ & & & \\
\hline & & {$[-0.03]$} & & & \\
\hline \multirow[t]{3}{*}{ EURO } & & & 1.28 & & \\
\hline & & & $(0.33)$ & & \\
\hline & & & {$[0.70]$} & & \\
\hline \multirow[t]{3}{*}{ SINGAPORE } & & & & -1.99 & \\
\hline & & & & $(-0.33)$ & \\
\hline & & & & {$[-0.42]$} & \\
\hline \multirow[t]{3}{*}{ UK } & & & & & 1.35 \\
\hline & & & & & $(0.40)$ \\
\hline & & & & & {$[0.48]$} \\
\hline R-Squared & 0.02 & 0.00 & 0.00 & 0.00 & 0.00 \\
\hline Panel B: Ethereum Period & $(1)$ & $(2)$ & $(3)$ & $(4)$ & $(5)$ \\
\hline \multirow[t]{3}{*}{ APLHA } & $13.70^{* * *}$ & $13.69^{* * *}$ & $13.93^{* * *}$ & $13.66^{* * *}$ & $12.82^{* * * *}$ \\
\hline & $(3.12)$ & $(3.11)$ & $(3.17)$ & $(3.11)$ & $(2.95)$ \\
\hline & {$[3.31]$} & {$[3.39]$} & {$[3.59]$} & {$[3.36]$} & {$[3.26]$} \\
\hline \multirow[t]{3}{*}{ AUSTRALIA } & -0.60 & & & & \\
\hline & $(-0.36)$ & & & & \\
\hline & {$[-0.47]$} & & & & \\
\hline \multirow[t]{3}{*}{ CANADA } & & -0.04 & & & \\
\hline & & $(-0.02)$ & & & \\
\hline & & {$[-0.02]$} & & & \\
\hline \multirow[t]{3}{*}{ EURO } & & & -1.15 & & \\
\hline & & & $(-0.55)$ & & \\
\hline & & & {$[-0.65]$} & & \\
\hline \multirow[t]{3}{*}{ SINGAPORE } & & & & 0.77 & \\
\hline & & & & $(0.27)$ & \\
\hline & & & & {$[0.33]$} & \\
\hline \multirow[t]{3}{*}{ UK } & & & & & -1.84 \\
\hline & & & & & $(-1.23)$ \\
\hline & & & & & {$[-1.91]$} \\
\hline R-Squared & 0.00 & 0.00 & 0.01 & 0.00 & 0.05 \\
\hline
\end{tabular}

We further test cryptocurrency exposures on currency factors as in Lustig, Roussanov, and Verdelhan (2011) instead of individual currency returns. ${ }^{7}$ Table 10 reports the results for each of the three cryptocurrencies. Consistent with the results on individual currency returns, we find that none of the three cryptocurrencies has significant exposures to the currency factors.

\footnotetext{
${ }^{7}$ We thank Nicola Borri for providing us with the up-to-date currency factors.
} 
Table 10: Currency Loadings of Cryptocurrency Factors

\begin{tabular}{|c|c|c|c|}
\hline Panel A: Bitcoin & (1) & $(2)$ & (3) \\
\hline \multirow[t]{3}{*}{ APLHA } & $0.23^{* * *}$ & $0.21^{* * *}$ & $0.21^{* * *}$ \\
\hline & $(3.04)$ & $(2.75)$ & $(2.78)$ \\
\hline & {$[3.14]$} & {$[2.77]$} & {$[2.76]$} \\
\hline \multirow[t]{3}{*}{ DOLLAR } & 3.18 & & 2.56 \\
\hline & $(0.75)$ & & $(0.59)$ \\
\hline & {$[0.56]$} & & {$[0.43]$} \\
\hline \multirow[t]{3}{*}{ CARRY } & & 3.88 & 3.41 \\
\hline & & $(0.92)$ & $(0.79)$ \\
\hline & & {$[1.53]$} & {$[1.23]$} \\
\hline R-Squared & 0.01 & 0.01 & 0.01 \\
\hline Panel B: Ripple & (1) & $(2)$ & (3) \\
\hline \multirow{3}{*}{ APLHA } & $0.40^{* *}$ & $0.42^{* *}$ & $0.43^{* *}$ \\
\hline & $(2.04)$ & $(2.01)$ & $(2.04)$ \\
\hline & {$[2.50]$} & {$[2.60]$} & {$[2.53]$} \\
\hline \multirow[t]{3}{*}{ DOLLAR } & 9.01 & & 8.65 \\
\hline & $(0.72)$ & & $(0.68)$ \\
\hline & {$[0.70]$} & & {$[0.67]$} \\
\hline \multirow[t]{3}{*}{ CARRY } & & -5.70 & -5.14 \\
\hline & & $(-0.47)$ & $(-0.42)$ \\
\hline & & {$[-1.13]$} & {$[-1.01]$} \\
\hline R-Squared & 0.01 & 0.00 & 0.01 \\
\hline Panel C: Ethereum & (1) & $(2)$ & (3) \\
\hline \multirow[t]{3}{*}{ APLHA } & $0.32^{* *}$ & $0.32^{* *}$ & $0.30^{* *}$ \\
\hline & $(2.71)$ & $(2.47)$ & $(2.37)$ \\
\hline & {$[2.62]$} & {$[2.43]$} & {$[2.30]$} \\
\hline \multirow[t]{3}{*}{ DOLLAR } & 10.81 & & 11.09 \\
\hline & $(1.43)$ & & $(1.43)$ \\
\hline & {$[1.46]$} & & {$[1.45]$} \\
\hline \multirow[t]{3}{*}{ CARRY } & & 1.15 & 2.24 \\
\hline & & $(0.17)$ & $(0.33)$ \\
\hline & & {$[0.22]$} & {$[0.46]$} \\
\hline R-Squared & 0.06 & 0.00 & 0.06 \\
\hline
\end{tabular}

\subsection{Precious Metals Commodities}

Table 11 shows commodity exposures of Bitcoin, Ripple, and Ethereum returns. For commodity returns, we consider gold, platinum, and crude oil. With the exception of the exposure of Ethereum to gold, the exposures of all other cryptocurrencies to these commodities are not statistically significant. At the same time, note that the alphas of Bitcoin and Ripple decrease, respectively, when gold and platinum are considered. In Table 12, we investigate the commodity exposures of Bitcoin returns over shorter periods corresponding to those of Ripple and Ethereum. During the Ripple period, Bitcoin negatively covaries with gold and platinum returns, similar to Ripple. For the Ethereum period, Bitcoin negatively covariates with platinum returns, in contrast with the behavior of Ethereum. We conclude that there is no consistent evidence of systematic commodity exposures in cryptocurrencies. 
Table 11: Commodity Loadings of Cryptocurrency Returns

\begin{tabular}{|c|c|c|c|}
\hline Panel A: Bitcoin & (1) & (2) & (3) \\
\hline \multirow[t]{3}{*}{ APLHA } & $22.46^{* * *}$ & $21.82^{* * *}$ & $22.56^{* * *}$ \\
\hline & $(3.00)$ & $(2.87)$ & $(3.01)$ \\
\hline & {$[3.04]$} & {$[3.66]$} & {$[3.11]$} \\
\hline \multirow[t]{3}{*}{ GOLD } & -0.64 & & \\
\hline & $(-0.42)$ & & \\
\hline & {$[-0.28]$} & & \\
\hline \multirow[t]{3}{*}{ PLATINUM } & & -0.08 & \\
\hline & & $(-0.06)$ & \\
\hline & & {$[-0.08]$} & \\
\hline \multirow[t]{3}{*}{ SILVER } & & & 0.38 \\
\hline & & & $(0.47)$ \\
\hline & & & {$[0.23]$} \\
\hline R-Squared & 0.00 & 0.00 & 0.00 \\
\hline Panel B: Ripple & $(1)$ & $(2)$ & $(3)$ \\
\hline \multirow[t]{3}{*}{ APLHA } & $41.26^{*}$ & $35.71^{*}$ & $37.73^{*}$ \\
\hline & $(1.99)$ & $(1.84)$ & $(1.95)$ \\
\hline & {$[2.27]$} & {$[2.51]$} & {$[2.50]$} \\
\hline \multirow[t]{3}{*}{ GOLD } & -2.56 & & \\
\hline & $(-0.49)$ & & \\
\hline & {$[-0.52]$} & & \\
\hline \multirow[t]{3}{*}{ PLATINUM } & & -3.54 & \\
\hline & & $(-0.99)$ & \\
\hline & & {$[-1.62]$} & \\
\hline \multirow[t]{3}{*}{ SILVER } & & & -2.42 \\
\hline & & & $(-0.79)$ \\
\hline & & & {$[-1.01]$} \\
\hline R-Squared & 0.00 & 0.02 & 0.01 \\
\hline Panel C: Ethereum & $(1)$ & $(2)$ & $(3)$ \\
\hline \multirow[t]{3}{*}{ APLHA } & $36.98^{* * *}$ & $32.97^{* *}$ & $32.59^{* *}$ \\
\hline & $(3.03)$ & $(2.72)$ & $(2.68)$ \\
\hline & {$[3.16]$} & {$[2.74]$} & {$[2.78]$} \\
\hline \multirow[t]{3}{*}{ GOLD } & $5.41^{*}$ & & \\
\hline & $(1.78)$ & & \\
\hline & {$[1.84]$} & & \\
\hline \multirow[t]{3}{*}{ PLATINUM } & & 0.97 & \\
\hline & & $(0.50)$ & \\
\hline & & {$[0.46]$} & \\
\hline \multirow[t]{3}{*}{ SILVER } & & & 0.57 \\
\hline & & & $(0.28)$ \\
\hline & & & {$[0.31]$} \\
\hline R-Squared & 0.11 & 0.01 & 0.00 \\
\hline
\end{tabular}


Table 12: Commodity Loadings of Bitcoin Returns - Different Period

\begin{tabular}{|c|c|c|c|c|c|c|c|}
\hline Panel A: Ripple Period & $(1)$ & $(2)$ & $(3)$ & Panel B: Ethereum Period & $(1)$ & $(2)$ & $(3)$ \\
\hline \multirow[t]{3}{*}{ APLHA } & $16.10^{*}$ & $15.29^{*}$ & $15.72^{*}$ & APLHA & $13.80^{* * *}$ & $13.76^{* * *}$ & $13.68^{* * * *}$ \\
\hline & $(1.87)$ & $(1.73)$ & $(1.81)$ & & $(3.10)$ & $(3.14)$ & $(3.11)$ \\
\hline & {$[2.14]$} & {$[2.35]$} & {$[2.25]$} & & {$[3.50]$} & {$[3.33]$} & {$[3.39]$} \\
\hline \multirow[t]{3}{*}{ GOLD } & -3.56 & & & GOLD & -0.10 & & \\
\hline & $(-1.60)$ & & & & $(-0.08)$ & & \\
\hline & {$[-1.03]$} & & & & {$[-0.12]$} & & \\
\hline \multirow[t]{3}{*}{ PLATINUM } & & -1.03 & & PLATINUM & & 0.25 & \\
\hline & & $(-0.63)$ & & & & $(0.35)$ & \\
\hline & & {$[-0.54]$} & & & & {$[0.41]$} & \\
\hline \multirow[t]{3}{*}{ SILVER } & & & -1.60 & SILVER & & & 0.11 \\
\hline & & & $(-1.17)$ & & & & $(0.14)$ \\
\hline & & & {$[-0.80]$} & & & & {$[0.23]$} \\
\hline R-Squared & 0.04 & 0.01 & 0.02 & R-Squared & 0.00 & 0.00 & 0.00 \\
\hline
\end{tabular}

\subsection{Exploring the Factor Zoo}

Finance literature has documented more than a hundred factors for predicting the cross-section of stock returns (see, e.g., summarizes in Feng, Giglio, and Xiu, 2017 and Chen and Velikov, 2017). To investigate whether any of those factors may be important in pricing cryptocurrencies, we estimate the loadings of the 155 common factors from Andrew Chen's website. One caveat is that this dataset ends at the end of 2016 and thus does not cover the most recent return experiences. Therefore, it can only be meaningfully used for the analysis of Bitcoin. We report the results in the Appendix, due to the large number of factors. We find that only four out of the 155 factors are significant, but those four factors do not form any discernible patterns.

\subsection{Macroeconomic Factors}

Table 13 shows macroeconomic factor exposures of Bitcoin, Ripple, and Ethereum returns. For macroeconomic factors, we consider the log non-durable consumption growth, log durable consumption growth, log industrial production growth, and log personal income growth. For Bitcoin and Ripple, all of the exposures are not statistically significant. ${ }^{8}$ For Ethereum, notably, the durable consumption growth factor has a significant loading.

\footnotetext{
${ }^{8}$ In the Appendix, we also report the results for Bitcoin for the time periods corresponding to those of Ripple and Ethereum. The results are the same as for the full sample.
} 
Table 13: Macro Factor Loadings of Cryptocurrency Returns

\begin{tabular}{|c|c|c|c|c|c|c|c|c|}
\hline Panel A: Bitcoin & (1) & $(2)$ & (3) & (4) & (5) & (6) & (7) & $(8)$ \\
\hline \multirow[t]{3}{*}{$\alpha$} & 0.09 & $0.25^{* * * *}$ & $0.23^{* * *}$ & $0.24^{* * * *}$ & 0.08 & $0.22^{* * *}$ & $0.19^{* *}$ & $0.20^{* *}$ \\
\hline & $(0.67)$ & $(3.16)$ & $(2.92)$ & $(2.90)$ & $(0.60)$ & $(2.67)$ & $(2.32)$ & $(2.34)$ \\
\hline & {$[0.94]$} & {$[3.04]$} & {$[3.01]$} & {$[3.33]$} & {$[0.84]$} & {$[2.91]$} & {$[2.80]$} & {$[3.19]$} \\
\hline \multirow[t]{3}{*}{$\Delta c^{n d}$} & 40.37 & & & & 33.71 & & & \\
\hline & $(1.09)$ & & & & $(0.90)$ & & & \\
\hline & {$[1.07]$} & & & & {$[0.93]$} & & & \\
\hline \multirow[t]{3}{*}{$\Delta c^{d}$} & & -7.25 & & & & -8.79 & & \\
\hline & & $(-0.98)$ & & & & $(-1.18)$ & & \\
\hline & & {$[-0.96]$} & & & & {$[-1.10]$} & & \\
\hline \multirow[t]{3}{*}{ sindpro } & & & -2.08 & & & & -0.14 & \\
\hline & & & $(-0.13)$ & & & & $(-0.01)$ & \\
\hline & & & {$[-0.16]$} & & & & {$[-0.01]$} & \\
\hline \multirow[t]{3}{*}{$\Delta p i$} & & & & -4.26 & & & & -3.54 \\
\hline & & & & $(-0.40)$ & & & & $(-0.34)$ \\
\hline & & & & {$[-0.86]$} & & & & {$[-0.76]$} \\
\hline \multirow[t]{3}{*}{ MKTRF } & & & & & 3.05 & 3.69 & 3.34 & 3.30 \\
\hline & & & & & $(1.31)$ & $(1.59)$ & $(1.44)$ & $(1.43)$ \\
\hline & & & & & {$[2.02]$} & {$[2.27]$} & {$[2.11]$} & {$[2.03]$} \\
\hline R-Squared & 0.01 & 0.01 & 0.00 & 0.00 & 0.03 & 0.04 & 0.02 & 0.03 \\
\hline Panel B: Ripple & $(1)$ & $(2)$ & (3) & $(4)$ & $(5)$ & $(6)$ & $(7)$ & $(8)$ \\
\hline \multirow[t]{3}{*}{$\alpha$} & -0.11 & $0.39^{*}$ & $0.33^{*}$ & 0.32 & -0.11 & $0.37^{*}$ & 0.31 & 0.32 \\
\hline & $(-0.26)$ & $(1.90)$ & $(1.69)$ & $(0.96)$ & $(-0.26)$ & $(1.73)$ & $(1.49)$ & $(0.96)$ \\
\hline & {$[-0.39]$} & {$[2.49]$} & {$[2.57]$} & {$[1.89]$} & {$[-0.40]$} & {$[2.34]$} & {$[2.39]$} & {$[1.91]$} \\
\hline \multirow[t]{3}{*}{$\Delta c^{n d}$} & 137.57 & & & & 138.82 & & & \\
\hline & $(1.31)$ & & & & $(1.27)$ & & & \\
\hline & {$[1.48]$} & & & & {$[1.54]$} & & & \\
\hline \multirow[t]{3}{*}{$\Delta c^{d}$} & & -1.96 & & & & -2.37 & & \\
\hline & & $(-0.11)$ & & & & $(-0.13)$ & & \\
\hline & & {$[-0.21]$} & & & & {$[-0.26]$} & & \\
\hline \multirow[t]{3}{*}{ sindpro } & & & 50.99 & & & & 51.72 & \\
\hline & & & $(1.33)$ & & & & $(1.34)$ & \\
\hline & & & {$[1.78]$} & & & & {$[1.77]$} & \\
\hline \multirow[t]{3}{*}{$\Delta p i$} & & & & 18.53 & & & & 14.13 \\
\hline & & & & $(0.22)$ & & & & $(0.16)$ \\
\hline & & & & {$[0.38]$} & & & & {$[0.28]$} \\
\hline \multirow[t]{3}{*}{ MKTRF } & & & & & -0.36 & 1.64 & 2.10 & 1.25 \\
\hline & & & & & $(-0.05)$ & $(0.24)$ & $(0.31)$ & $(0.18)$ \\
\hline & & & & & {$[-0.13]$} & {$[0.47]$} & {$[0.62]$} & {$[0.35]$} \\
\hline R-Squared & 0.03 & 0.00 & 0.03 & 0.00 & 0.03 & 0.00 & 0.03 & 0.00 \\
\hline
\end{tabular}




\begin{tabular}{|c|c|c|c|c|c|c|c|c|}
\hline Panel C: Ethereum & $(1)$ & $(2)$ & (3) & $(4)$ & $(6)$ & $(7)$ & $(8)$ & (9) \\
\hline \multirow[t]{3}{*}{$\alpha$} & 0.38 & $0.39 * * *$ & $0.33^{* *}$ & $0.44^{* *}$ & 0.38 & $0.38 * * *$ & $0.31^{* *}$ & $0.45^{* *}$ \\
\hline & $(1.47)$ & $(3.22)$ & $(2.66)$ & $(2.46)$ & $(1.41)$ & $(2.95)$ & $(2.36)$ & $(2.50)$ \\
\hline & {$[1.58]$} & {$[3.40]$} & {$[2.86]$} & {$[2.51]$} & {$[1.46]$} & {$[2.97]$} & {$[2.48]$} & {$[2.54]$} \\
\hline \multirow[t]{3}{*}{$\Delta c^{n d}$} & -15.50 & & & & -17.29 & & & \\
\hline & $(-0.24)$ & & & & $(-0.26)$ & & & \\
\hline & {$[-0.24]$} & & & & {$[-0.27]$} & & & \\
\hline \multirow[t]{3}{*}{$\Delta c^{d}$} & & $-20.41^{*}$ & & & & -20.15 & & \\
\hline & & $(-1.71)$ & & & & $(-1.66)$ & & \\
\hline & & {$[-2.71]$} & & & & {$[-2.27]$} & & \\
\hline \multirow[t]{3}{*}{$\Delta$ indpro } & & & 0.78 & & & & 2.93 & \\
\hline & & & $(0.03)$ & & & & $(0.12)$ & \\
\hline & & & {$[0.04]$} & & & & {$[0.12]$} & \\
\hline \multirow[t]{3}{*}{$\Delta p i$} & & & & -44.94 & & & & -61.15 \\
\hline & & & & $(-0.85)$ & & & & $(-1.07)$ \\
\hline & & & & {$[-0.99]$} & & & & {$[-1.12]$} \\
\hline \multirow[t]{3}{*}{ MKTRF } & & & & & 1.68 & 1.16 & 1.72 & 3.26 \\
\hline & & & & & $(0.42)$ & $(0.30)$ & $(0.42)$ & $(0.77)$ \\
\hline & & & & & {$[0.45]$} & {$[0.32]$} & {$[0.47]$} & {$[0.79]$} \\
\hline R-Squared & 0.00 & 0.09 & 0.00 & 0.02 & 0.01 & 0.09 & 0.01 & 0.04 \\
\hline
\end{tabular}

\section{Cryptocurrency Specific Factors}

In this section, we first develop and investigate cryptocurrency specific predictors. We consider momentum, proxies for investor attention, proxies for the price-to-"dividend" ratio, and the volatility - all of which are specific to the individual cryptocurrency markets. Finally, we construct proxies for cryptocurrency supply conditions. Throughout this section, t-statistics in parentheses and brackets are based on regular and bootstrapped standard errors.

\subsection{Cryptocurrency Momentum}

We first establish that there is very strong evidence of momentum at various time horizons. Table 14 documents the time-series momentum results. For Bitcoin daily returns, the current return positively and statistically significantly predicts 1 -day, 3-day, 5-day, and 6-day ahead returns. A one standard deviation increase in today's return leads to increases in daily returns by 0.33 percent, ${ }^{9} 0.17$ percent, 0.39 percent, and 0.50 percent increases at the 1-day, 3-day, 5-day, and 6-day ahead returns, respectively. Specifically, the 1-day ahead daily return is that of buying a Bitcoin at 11:59:59 UTD today and selling at 11:59:59 UTD one day later.

For Bitcoin weekly returns, the current return positively and statistically significantly predicts 1-week, 2-week, 3-week, and 4-week ahead returns. A one-standard-deviation increase in this week's return leads to increases in weekly returns of 3.16 percent, ${ }^{10} 3.66$ percent, 3.49 percent, and 1.50 percent increases at the 1-week, 2-week, 3-week, and 4-week ahead returns, respectively. Specifically, the 1-week ahead weekly return is that of buying a Bitcoin at 11:59:59 UTD Sunday and selling at 11:59:59 UTD one week later.

\footnotetext{
${ }^{9}$ The 0.33 percent daily return is calculated by multiplying a one-standard-deviation increase of today's return ( 5.55 percent) and the coefficient estimate (0.06).

${ }^{10}$ The 3.16 percent weekly return is calculated by multiplying one-standard-deviation increase of today's return (16.64 percent) and the coefficient estimate (0.19).
} 
In Table 15, we estimate the time-series momentum by grouping weekly returns into quintiles and evaluating their performance going forward. We find that the top quintiles outperform the bottom quintiles at 1-4 week ahead horizons. For example, at the 1-week horizon, the average return of the top quintile is 11.22 percent per week with the Sharpe ratio of 0.45 while the average return of the bottom quintile is 2.60 percent per week with the Sharpe ratio of 0.19. In Table 16, we restrict our sample to 2013 onward. Again, we find a strong and statistically significant momentum effect of somewhat smaller magnitude. ${ }^{11}$ In Table 17 , we use the first two years of data to determine the quintile cutoffs and study the out-of-sample momentum performance, and we find strong momentum effect as well.

Table 14: Time-Series Momentum

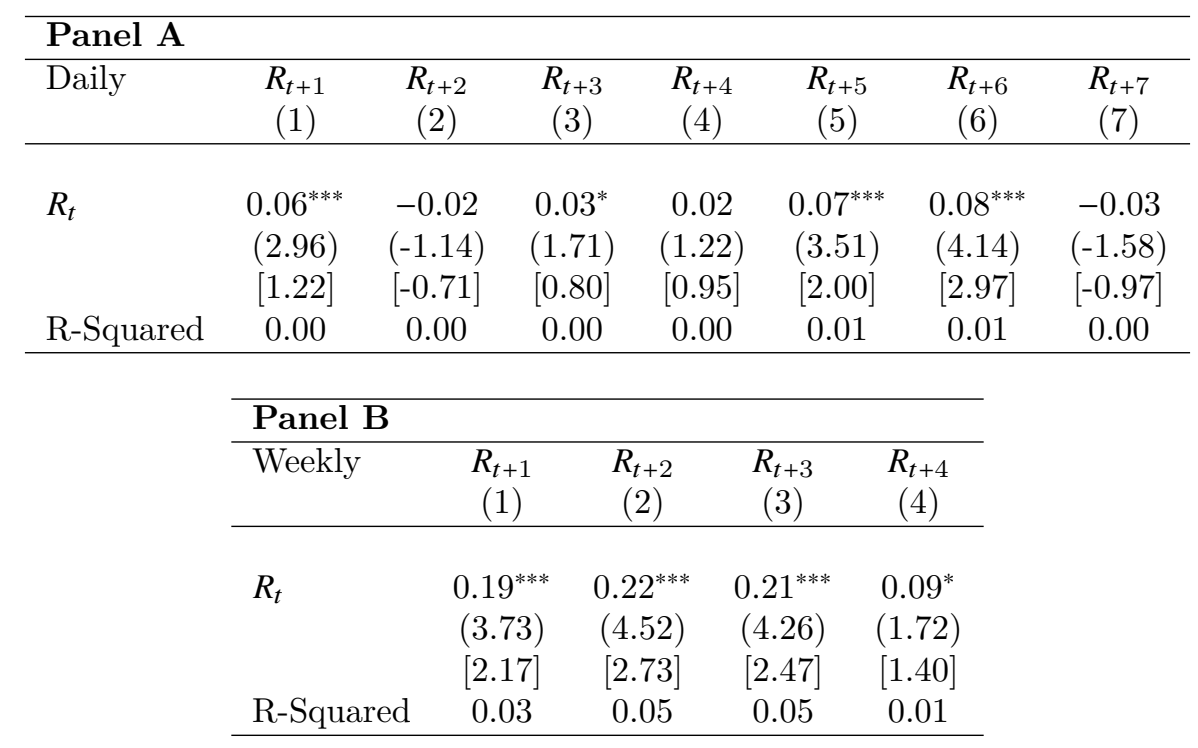

\footnotetext{
${ }^{11}$ Stoffels (2017) documents that a cross-sectional momentum strategy based on 15 cryptocurrencies generate abnormal returns during the period between 2016 and 2017.
} 
Table 15: Time-Series Momentum by Groups

\begin{tabular}{|c|c|c|c|c|c|c|c|}
\hline \multicolumn{8}{|c|}{ Weekly Level (Percentage) } \\
\hline Rank & Formation Return & $R_{t+1}$ & T-Statistics & Sharpe & $R_{t+2}$ & T-Statistics & Sharpe \\
\hline Low & -14.95 & $2.60^{*}$ & $(1.69)$ & 0.19 & -1.23 & $(-0.89)$ & -0.10 \\
\hline 2 & -2.56 & 0.27 & $(0.19)$ & 0.02 & $4.40^{* *}$ & $(2.32)$ & 0.26 \\
\hline 3 & 1.84 & 1.15 & $(0.87)$ & 0.10 & $2.92^{* *}$ & $(2.52)$ & 0.29 \\
\hline 4 & 7.59 & $3.75^{*}$ & $(2.20)$ & 0.25 & $2.62^{*}$ & $(1.71)$ & 0.19 \\
\hline 5 & 27.44 & $11.22^{* * *}$ & $(3.95)$ & 0.45 & $10.05^{* * *}$ & $(3.52)$ & 0.40 \\
\hline Difference & & 8.62 & & & 11.28 & & \\
\hline Rank & Formation Return & $R_{t+3}$ & T-Statistics & Sharpe & $R_{t+4}$ & T-Statistics & Sharpe \\
\hline Low & -14.95 & -0.50 & $(-0.38)$ & -0.04 & 1.73 & $(1.03)$ & 0.12 \\
\hline 2 & -2.56 & 2.40 & $(1.35)$ & 0.15 & 2.13 & $(1.29)$ & 0.15 \\
\hline 3 & 1.84 & $3.62^{* *}$ & $(2.24)$ & 0.26 & $2.42^{*}$ & (1.81) & 0.21 \\
\hline 4 & 7.59 & $3.04^{*}$ & (1.83) & 0.21 & $5.31^{* * *}$ & $(2.81)$ & 0.32 \\
\hline 5 & 27.44 & $10.07^{* * *}$ & $(3.76)$ & 0.43 & $6.92^{* *}$ & $(2.59)$ & 0.30 \\
\hline Difference & & 10.57 & & & 5.18 & & \\
\hline
\end{tabular}

Table 16: Time-Series Momentum by Groups Since 2013

\begin{tabular}{|c|c|c|c|c|c|c|c|}
\hline \multicolumn{8}{|c|}{ Weekly Level (Percentage) } \\
\hline Rank & Formation Return & $R_{t+1}$ & T-Statistics & Sharpe & $R_{t+2}$ & T-Statistics & Sharpe \\
\hline Low & -14.38 & 2.83 & $(1.62)$ & 0.22 & -0.01 & $(-0.01)$ & -0.00 \\
\hline 2 & -2.40 & 0.64 & $(0.49)$ & 0.07 & 1.31 & $(1.00)$ & 0.13 \\
\hline 3 & 1.75 & 0.91 & $(0.56)$ & 0.07 & $3.38^{* *}$ & $(2.41)$ & 0.32 \\
\hline 4 & 7.57 & $4.04^{* *}$ & $(2.66)$ & 0.35 & 2.95 & $(1.69)$ & 0.23 \\
\hline 5 & 23.53 & $7.18^{* *}$ & $(2.57)$ & 0.34 & $7.8^{* * *}$ & $(2.80)$ & 0.37 \\
\hline Difference & & 4.35 & & & 7.87 & & \\
\hline Rank & Formation Return & $R_{t+3}$ & T-Statistics & Sharpe & $R_{t+4}$ & T-Statistics & Sharpe \\
\hline Low & -14.38 & 0.81 & $(0.56)$ & 0.07 & 1.97 & $(1.10)$ & 0.15 \\
\hline 2 & -2.40 & 0.80 & $(0.52)$ & 0.07 & 1.88 & (1.41) & 0.19 \\
\hline 3 & 1.75 & $4.06^{* *}$ & $(2.03)$ & 0.27 & 0.76 & $(0.48)$ & 0.06 \\
\hline 4 & 7.57 & 2.70 & (1.49) & 0.20 & $5.41^{* * *}$ & $(3.02)$ & 0.40 \\
\hline 5 & 23.53 & $6.90^{* * *}$ & $(2.83)$ & 0.38 & $5.00^{*}$ & $(1.86)$ & 0.25 \\
\hline Difference & & 6.09 & & & 3.03 & & \\
\hline
\end{tabular}


Table 17: Time-Series Momentum by Groups - No Lookahead

\begin{tabular}{|c|c|c|c|c|c|c|c|}
\hline \multicolumn{8}{|c|}{ Weekly Level (Percentage) } \\
\hline Rank & Formation Return & $R_{t+1}$ & T-Statistics & Sharpe & $R_{t+2}$ & T-Statistics & Sharpe \\
\hline Low & -14.97 & $3.35^{*}$ & $(1.82)$ & 0.25 & 0.09 & $(0.05)$ & 0.01 \\
\hline 2 & -2.88 & 0.39 & $(0.31)$ & 0.04 & 0.78 & $(0.65)$ & 0.09 \\
\hline 3 & 1.77 & 1.33 & $(0.91)$ & 0.11 & $3.52^{* * *}$ & $(2.75)$ & 0.33 \\
\hline 4 & 8.12 & $3.25^{* *}$ & $(2.10)$ & 0.28 & 2.87 & $(1.60)$ & 0.22 \\
\hline 5 & 24.14 & $7.88^{* *}$ & $(2.70)$ & 0.37 & $8.32^{* * *}$ & $(2.83)$ & 0.39 \\
\hline Difference & & 4.53 & & & 8.23 & & \\
\hline Rank & Formation Return & $R_{t+3}$ & T-Statistics & Sharpe & $R_{t+4}$ & T-Statistics & Sharpe \\
\hline Low & -14.97 & 1.37 & $(0.90)$ & 0.12 & 2.60 & $(1.36)$ & 0.19 \\
\hline 2 & -2.88 & 0.00 & $(-0.00)$ & 0.00 & 1.21 & $(0.90)$ & 0.12 \\
\hline 3 & 1.77 & $3.99^{* *}$ & $(2.33)$ & 0.28 & 1.68 & $(1.20)$ & 0.15 \\
\hline 4 & 8.12 & 2.58 & (1.36) & 0.18 & $5.36^{* * *}$ & $(2.95)$ & 0.40 \\
\hline 5 & 24.14 & $7.53^{* * *}$ & (2.98) & 0.41 & $5.02^{*}$ & (1.77) & 0.24 \\
\hline Difference & & 6.16 & & & 2.42 & & \\
\hline
\end{tabular}

Table 18 summarizes evidence for Ripple and Ethereum. For Ripple, the momentum effect is statistically significant at the 1-5 day horizon. For Ethereum, the momentum effect is statistically significant at the 1-day and 5-day horizons, with the 5-day horizon coefficient having a negative sign.

Table 18: Time-Series Momentum of Ripple and Ethereum

\begin{tabular}{|c|c|c|c|c|c|c|c|}
\hline \multicolumn{8}{|c|}{ Panel A: Ripple } \\
\hline Daily & $\begin{array}{c}R_{t+1} \\
(1)\end{array}$ & $\begin{array}{c}R_{t+2} \\
(2)\end{array}$ & $\begin{array}{c}R_{t+3} \\
(3) \\
\end{array}$ & $\begin{array}{c}R_{t+4} \\
(4)\end{array}$ & $\begin{array}{c}R_{t+5} \\
(5)\end{array}$ & $\begin{array}{c}R_{t+6} \\
(6)\end{array}$ & $\begin{array}{c}R_{t+7} \\
(7) \\
\end{array}$ \\
\hline \multirow[t]{3}{*}{$R_{t}$} & $0.06^{* *}$ & $0.08^{* * *}$ & $0.05^{*}$ & $0.04^{*}$ & $0.06^{* *}$ & 0.03 & 0.03 \\
\hline & $(2.49)$ & $(3.59)$ & $(1.94)$ & $(1.83)$ & $(2.53)$ & $(1.35)$ & $(1.27)$ \\
\hline & [0.61] & {$[1.73]$} & {$[0.88]$} & {$[1.32]$} & {$[2.02]$} & {$[1.23]$} & {$[0.63]$} \\
\hline R-Squared & 0.00 & 0.01 & 0.00 & 0.00 & 0.00 & 0.00 & 0.00 \\
\hline \multicolumn{8}{|c|}{ Panel B: Ethereum } \\
\hline Daily & $\begin{array}{c}R_{t+1} \\
(1)\end{array}$ & $\begin{array}{c}R_{t+2} \\
(2)\end{array}$ & $\begin{array}{c}R_{t+3} \\
(3)\end{array}$ & $\begin{array}{c}R_{t+4} \\
(4)\end{array}$ & $\begin{array}{c}R_{t+5} \\
(5)\end{array}$ & $\begin{array}{c}R_{t+6} \\
(6)\end{array}$ & $\begin{array}{c}R_{t+7} \\
(7)\end{array}$ \\
\hline \multirow[t]{3}{*}{$R_{t}$} & $0.08^{* *}$ & 0.04 & -0.01 & -0.04 & $-0.08^{* *}$ & 0.01 & 0.04 \\
\hline & $(2.58)$ & $(1.41)$ & $(-0.20)$ & $(-1.48)$ & $(-2.63)$ & $(0.23)$ & $(1.46)$ \\
\hline & {$[1.67]$} & {$[0.73]$} & {$[-0.10]$} & {$[-1.07]$} & {$[-1.10]$} & {$[0.14]$} & {$[1.06]$} \\
\hline R-Squared & 0.01 & 0.00 & 0.00 & 0.00 & 0.01 & 0.00 & 0.00 \\
\hline
\end{tabular}

\subsection{Cryptocurrency Investor Attention}

In this section, we investigate the role of investor attention for the cryptocurrency returns. Specifically, we construct the deviation of Google searches for the words "Bitcoin", "Ripple", and "Ethereum" in a given 
week compared to the average of those in the preceding four weeks. We match Google searches for the word "Bitcoin" with Bitcoin data, searches for the word "Ripple" with Ripple data, and searches for the word "Ethereum" with Ethereum data.

Table 19 reports the results for Bitcoin. For weekly returns, the Google search proxy statistically significantly predicts 1-week and 2-week ahead returns. A one-standard-deviation increase in this week's searches leads to increases in weekly returns of 1.84 percent and 2.30 percent at the 1 -week and 2 -week ahead returns. ${ }^{12}$

In Table 20, we investigate the Google search proxy by grouping the weekly Google search deviations into quintiles and evaluating their performance going forward. We find that the top quintile outperforms the bottom quintile at 1-4 week ahead horizons. For example, at the 1-week horizon, the average return of the top quintile is 11.20 percent per week with the Sharpe ratio of 0.48 while the average return of the bottom quintile is 1.07 percent per week with the Sharpe ratio of 0.08 .

Table 21 reports the same calculation for the more recent period since 2013. The results are similar to that of the full sample. The top quintile outperforms the bottom quintile at the 1-4 week ahead horizons. For example, at the 2-week horizon, the average return of the top quintile is 8.90 percent with the Sharpe ratio of 0.40 while the average return of the bottom quintile is 0.57 percent per week with the Sharpe ratio of 0.04. In Table 22, we use the first two years of data to determine the quintile cutoffs and study the out-of-sample effect of investor attention, and we find strong positive investor attention effect as well.

Table 19: Google Searches - Bitcoin

Google search data for "Bitcoin" minus the average of previous four weeks, normalized.

\begin{tabular}{|c|c|c|c|c|c|c|c|}
\hline Weekly & $\begin{array}{c}R_{t+1} \\
(1)\end{array}$ & $\begin{array}{c}R_{t+2} \\
(2) \\
\end{array}$ & $\begin{array}{c}R_{t+3} \\
(3) \\
\end{array}$ & $\begin{array}{c}R_{t+4} \\
(4)\end{array}$ & $\begin{array}{c}R_{t+5} \\
(5)\end{array}$ & $\begin{array}{c}R_{t+6} \\
(6)\end{array}$ & $\begin{array}{c}R_{t+7} \\
(7)\end{array}$ \\
\hline Google $_{t}$ & $\begin{array}{l}1.84^{* *} \\
(2.17)\end{array}$ & $\begin{array}{c}2.30^{* * *} \\
(2.81)\end{array}$ & $\begin{array}{c}1.04 \\
(1.25)\end{array}$ & $\begin{array}{c}0.59 \\
(0.72)\end{array}$ & $\begin{array}{c}1.03 \\
(1.25)\end{array}$ & $\begin{array}{l}-0.01 \\
(-0.01)\end{array}$ & $\begin{array}{l}-1.30 \\
(-1.39)\end{array}$ \\
\hline & {$[1.76]$} & {$[2.07]$} & {$[0.76]$} & {$[0.54]$} & {$[1.00]$} & {$[-0.01]$} & {$[-1.34]$} \\
\hline R-Squared & 0.01 & 0.02 & 0.00 & 0.00 & 0.00 & 0.00 & 0.01 \\
\hline
\end{tabular}

\footnotetext{
${ }^{12}$ Wang and Vergne (2017) use the level of newspaper mentions of Bitcoin to proxy for the "buzz" of Bitcoin. They document that high "buzz" predicts low Bitcoin returns in the future. Mai et al. (2016) use the level of Twitter post counts to predict Bitcoin returns.
} 
Table 20: Google Searches by Groups

\begin{tabular}{lccccccc}
\hline Weekly Level (Percentage) & \multicolumn{7}{c}{} \\
\hline Rank & Google & $R_{t+1}$ & T-Statistics & Sharpe & $R_{t+2}$ & T-Statistics & Sharpe \\
\hline Low & -0.71 & 1.07 & $(0.74)$ & 0.08 & 0.34 & $(0.23)$ & 0.03 \\
2 & -0.05 & -1.20 & $(-1.06)$ & -0.11 & 0.24 & $(0.20)$ & 0.02 \\
3 & -0.01 & $3.92^{* *}$ & $(2.26)$ & 0.24 & $4.23^{* * *}$ & $(2.75)$ & 0.29 \\
4 & 0.04 & $6.03^{* *}$ & $(2.65)$ & 0.35 & $5.21^{* *}$ & $(2.36)$ & 0.31 \\
5 & 0.87 & $11.20^{* * *}$ & $(3.95)$ & 0.48 & $8.99^{* * *}$ & $(3.17)$ & 0.39 \\
\hline Difference & 10.13 & & & 8.66 & & \\
\hline \hline Rank & Google & $R_{t+3}$ & T-Statistics & Sharpe & $R_{t+4}$ & T-Statistics & Sharpe \\
\hline Low & -0.71 & -0.29 & $(-0.19)$ & -0.02 & 0.62 & $(0.39)$ & 0.05 \\
2 & -0.05 & 1.65 & $(1.47)$ & 0.15 & 1.31 & $(1.03)$ & 0.11 \\
3 & -0.01 & $4.35^{* *}$ & $(2.39)$ & 0.25 & $4.49^{* *}$ & $(2.57)$ & 0.27 \\
4 & 0.04 & $6.19^{* * *}$ & $(3.06)$ & 0.40 & $9.13^{* * *}$ & $(3.33)$ & 0.44 \\
5 & 0.87 & $6.54^{* *}$ & $(2.39)$ & 0.29 & 3.51 & $(1.67)$ & 0.20 \\
\hline Difference & 6.82 & \multicolumn{7}{c}{2.89} & & \\
\hline
\end{tabular}

Table 21: Google Searches by Groups Since 2013

\begin{tabular}{|c|c|c|c|c|c|c|c|}
\hline \multicolumn{8}{|c|}{ Weekly Level (Percentage) } \\
\hline Rank & Google & $R_{t+1}$ & T-Statistics & Sharpe & $R_{t+2}$ & T-Statistics & Sharpe \\
\hline Low & -0.77 & 0.21 & $(0.12)$ & 0.02 & 0.57 & $(0.30)$ & 0.04 \\
\hline 2 & -0.08 & 0.51 & $(0.42)$ & 0.05 & 0.62 & $(0.58)$ & 0.07 \\
\hline 3 & -0.01 & 1.26 & $(1.63)$ & 0.20 & $1.91^{* *}$ & $(2.04)$ & 0.25 \\
\hline 4 & 0.05 & $3.65^{*}$ & (1.94) & 0.28 & $4.93^{* *}$ & $(2.51)$ & 0.36 \\
\hline 5 & 0.94 & $11.60^{* * *}$ & $(3.67)$ & 0.51 & $8.90^{* * *}$ & $(2.84)$ & 0.40 \\
\hline Difference & & 11.39 & & & 8.33 & & \\
\hline Rank & Google & $R_{t+3}$ & T-Statistics & Sharpe & $R_{t+4}$ & T-Statistics & Sharpe \\
\hline Low & -0.77 & 0.78 & $(0.43)$ & 0.06 & 0.24 & $(0.14)$ & 0.02 \\
\hline 2 & -0.08 & 1.10 & $(0.89)$ & 0.11 & 1.86 & $(1.35)$ & 0.17 \\
\hline 3 & -0.01 & $1.85^{*}$ & $(1.74)$ & 0.22 & $1.93^{* *}$ & $(2.02)$ & 0.25 \\
\hline 4 & 0.05 & $6.26^{* * *}$ & $(2.85)$ & 0.41 & $7.79^{* * *}$ & $(2.96)$ & 0.43 \\
\hline 5 & 0.94 & $6.83^{* *}$ & $(2.29)$ & 0.32 & $4.75^{*}$ & $(1.78)$ & 0.25 \\
\hline Difference & & 6.05 & & & 4.51 & & \\
\hline
\end{tabular}


Table 22: Google Searches by Groups - No Lookahead

\begin{tabular}{|c|c|c|c|c|c|c|c|}
\hline \multicolumn{8}{|c|}{ Weekly Level (Percentage) } \\
\hline Rank & Google & $R_{t+1}$ & T-Statistics & Sharpe & $R_{t+2}$ & T-Statistics & Sharpe \\
\hline Low & -3.31 & 0.70 & $(0.54)$ & 0.06 & 0.32 & $(0.24)$ & 0.03 \\
\hline 2 & -0.25 & -0.29 & $(-0.21)$ & -0.04 & 1.96 & $(1.23)$ & 0.22 \\
\hline 3 & 0.00 & 1.10 & $(1.44)$ & 0.18 & $1.68^{*}$ & $(1.77)$ & 0.22 \\
\hline 4 & 0.21 & $5.44^{*}$ & $(1.64)$ & 0.39 & 5.70 & $(1.72)$ & 0.41 \\
\hline 5 & 4.08 & $8.10^{* * *}$ & $(3.70)$ & 0.41 & $7.25^{* * *}$ & $(3.33)$ & 0.37 \\
\hline Difference & & 7.39 & & & 6.94 & & \\
\hline Rank & Google & $R_{t+3}$ & T-Statistics & Sharpe & $R_{t+4}$ & T-Statistics & Sharpe \\
\hline Low & -3.31 & 0.61 & $(0.47)$ & 0.05 & 0.81 & $(0.64)$ & 0.07 \\
\hline 2 & -0.25 & 2.71 & $(1.64)$ & 0.29 & 2.78 & $(1.26)$ & 0.23 \\
\hline 3 & 0.00 & 1.48 & $(1.39)$ & 0.18 & 1.51 & $(1.61)$ & 0.20 \\
\hline 4 & 0.21 & $7.50^{* *}$ & $(2.13)$ & 0.50 & $10.33^{* *}$ & $(2.59)$ & 0.61 \\
\hline 5 & 4.08 & $6.34^{* * *}$ & $(2.96)$ & 0.33 & $5.31^{* *}$ & $(2.52)$ & 0.28 \\
\hline Difference & & 5.72 & & & 4.49 & & \\
\hline
\end{tabular}

Table 23 reports the results for Ripple. For weekly returns, the Google search proxy statistically significantly predicts 1-week ahead returns. A one-standard-deviation increase in this week's searches leads to increases in weekly returns of 10.86 percent at the 1-week ahead returns. The results for Bitcoin for the same period are comparable to those for other samples and to those for Ripple.

Table 23: Google Searches - Ripple

\begin{tabular}{|c|c|c|c|c|c|c|c|}
\hline \multicolumn{8}{|l|}{ Ripple } \\
\hline Weekly & $\begin{array}{c}R_{t+1} \\
(1)\end{array}$ & $\begin{array}{c}R_{t+2} \\
(2)\end{array}$ & $\begin{array}{c}R_{t+3} \\
(3)\end{array}$ & $\begin{array}{c}R_{t+4} \\
(4)\end{array}$ & $\begin{array}{c}R_{t+5} \\
(5)\end{array}$ & $\begin{array}{c}R_{t+6} \\
(6)\end{array}$ & $\begin{array}{c}R_{t+7} \\
(7) \\
\end{array}$ \\
\hline \multirow[t]{2}{*}{ Google $_{t}$} & $\begin{array}{c}10.86^{* * *} \\
(3.74)\end{array}$ & $\begin{array}{c}4.44 \\
(1.50)\end{array}$ & $\begin{array}{c}3.03 \\
(1.02)\end{array}$ & $\begin{array}{c}0.22 \\
(0.07)\end{array}$ & $\begin{array}{l}-1.39 \\
(-0.47)\end{array}$ & $\begin{array}{c}0.26 \\
(0.09)\end{array}$ & $\begin{array}{c}0.58 \\
(0.19)\end{array}$ \\
\hline & {$[2.62]$} & {$[1.32]$} & {$[0.67]$} & {$[0.11]$} & {$[-0.63]$} & {$[0.15]$} & {$[0.31]$} \\
\hline R-Squared & 0.05 & 0.01 & 0.00 & 0.00 & 0.00 & 0.00 & 0.00 \\
\hline \multicolumn{8}{|c|}{ Panel B: Same Period Bitcoin Result } \\
\hline Weekly & $\begin{array}{c}R_{t+1} \\
(1) \\
\end{array}$ & $\begin{array}{c}R_{t+2} \\
(2) \\
\end{array}$ & $\begin{array}{c}R_{t+3} \\
(3) \\
\end{array}$ & $\begin{array}{c}R_{t+4} \\
(4) \\
\end{array}$ & $\begin{array}{c}R_{t+5} \\
(5) \\
\end{array}$ & $\begin{array}{c}R_{t+6} \\
(6) \\
\end{array}$ & $\begin{array}{c}R_{t+7} \\
(7) \\
\end{array}$ \\
\hline \multirow[t]{2}{*}{ Google $_{t}$} & $\begin{array}{c}2.16^{* * *} \\
(2.74)\end{array}$ & $\begin{array}{c}2.59^{* * *} \\
(3.32)\end{array}$ & $\begin{array}{c}1.09 \\
(1.36)\end{array}$ & $\begin{array}{c}0.73 \\
(0.91)\end{array}$ & $\begin{array}{c}1.25 \\
(1.56)\end{array}$ & $\begin{array}{c}-0.07 \\
(-0.09)\end{array}$ & $\begin{array}{l}-1.47^{*} \\
(-1.84)\end{array}$ \\
\hline & {$[1.67]$} & {$[2.08]$} & {$[0.77]$} & {$[0.51]$} & {$[1.30]$} & {$[-0.06]$} & {$[-1.21]$} \\
\hline R-Squared & 0.06 & 0.04 & 0.01 & 0.00 & 0.01 & 0.00 & 0.01 \\
\hline
\end{tabular}

Table 24 reports the results for Ethereum. For weekly returns, the Google search proxy statistically significantly predicts 1 -week, 3 -week, and 6-week ahead returns. A one-standard-deviation increase in this week's searches leads to increases in weekly returns of 4.36 percent, 3.45 percent, and 3.65 percent at the 1-week, 3-week and 6-week ahead returns. The results for Bitcoin for the same period are comparable to those for other samples and to those for Ripple. 
Table 24: Google Searches - Ethereum

Google search data for the word "Ethereum" is minus the average of past four weeks and normalized.

\begin{tabular}{|c|c|c|c|c|c|c|c|}
\hline \multicolumn{8}{|c|}{ Panel A: Ethereum } \\
\hline Weekly & $\begin{array}{c}R_{t+1} \\
(1)\end{array}$ & $\begin{array}{c}R_{t+2} \\
(2) \\
\end{array}$ & $\begin{array}{c}R_{t+3} \\
(3) \\
\end{array}$ & $\begin{array}{c}R_{t+4} \\
(4) \\
\end{array}$ & $\begin{array}{c}R_{t+5} \\
(5)\end{array}$ & $\begin{array}{c}R_{t+6} \\
(6)\end{array}$ & $\begin{array}{c}R_{t+7} \\
(7) \\
\end{array}$ \\
\hline \multirow[t]{2}{*}{ Google $_{t}$} & $\begin{array}{l}4.36^{* *} \\
(2.36)\end{array}$ & $\begin{array}{c}1.92 \\
(1.02)\end{array}$ & $\begin{array}{c}3.45^{*} \\
(1.84)\end{array}$ & $\begin{array}{c}2.29 \\
(1.22)\end{array}$ & $\begin{array}{c}0.86 \\
(0.46)\end{array}$ & $\begin{array}{c}3.65^{*} \\
(1.96)\end{array}$ & $\begin{array}{c}0.95 \\
(0.50)\end{array}$ \\
\hline & [2.54] & {$[0.75]$} & [1.88] & [1.21] & {$[0.39]$} & {$[1.66]$} & [0.59] \\
\hline R-Squared & 0.04 & 0.01 & 0.02 & 0.01 & 0.00 & 0.03 & 0.00 \\
\hline \multicolumn{8}{|c|}{ Panel B: Same Period Bitcoin Result } \\
\hline Weekly & $\begin{array}{c}R_{t+1} \\
(1)\end{array}$ & $\begin{array}{c}R_{t+2} \\
(2) \\
\end{array}$ & $\begin{array}{c}R_{t+3} \\
(3) \\
\end{array}$ & $\begin{array}{c}R_{t+4} \\
(4) \\
\end{array}$ & $\begin{array}{c}R_{t+5} \\
(5)\end{array}$ & $\begin{array}{c}R_{t+6} \\
(6) \\
\end{array}$ & $\begin{array}{c}R_{t+7} \\
(7) \\
\end{array}$ \\
\hline \multirow[t]{2}{*}{ Google $_{t}$} & $2.28^{* *}$ & $3.03^{* * *}$ & $\begin{array}{l}1.31 \\
(1.35)\end{array}$ & 0.88 & 1.47 & -0.39 & $\begin{array}{l}-2.22 \\
(2.9)\end{array}$ \\
\hline & $\begin{array}{l}(2.38) \\
{[1.32]}\end{array}$ & $\begin{array}{l}(3.22) \\
{[1.95]}\end{array}$ & $\begin{array}{l}(1.35) \\
{[0.67]}\end{array}$ & $\begin{array}{l}(0.90) \\
{[0.56]}\end{array}$ & $\begin{array}{l}(1.52) \\
{[1.07]}\end{array}$ & $\begin{array}{l}(-0.40) \\
{[-0.24]}\end{array}$ & $\begin{array}{l}(-2.29) \\
{[-1.27]}\end{array}$ \\
\hline R-Squared & 0.04 & 0.07 & 0.01 & 0.01 & 0.02 & 0.00 & 0.03 \\
\hline
\end{tabular}

We are also interested in the question of whether past returns are associated with increases in investor attention. We regress this week's deviation in the Google searches on the contemporaneous and the previous four weeks Bitcoin returns. Table 25 documents the results. We find that the deviations in Google searches are significantly associated with the contemporaneous and previous weeks Bitcoin returns.

Table 25: Google Searches and Past Returns

\begin{tabular}{lccccc}
\hline Weekly & $\begin{array}{c}\text { Google }_{t} \\
(1)\end{array}$ & $\begin{array}{c}\text { Google }_{t} \\
(2)\end{array}$ & $\begin{array}{c}\text { Google }_{t} \\
(3)\end{array}$ & $\begin{array}{c}\text { Google }_{t} \\
(4)\end{array}$ & $\begin{array}{c}\text { Foogle }_{t} \\
(5)\end{array}$ \\
\hline \multirow{2}{*}{$R_{t}$} & & & & & \\
& $0.01^{* * *}$ & $0.01^{* * *}$ & $0.01^{* * *}$ & $0.01^{* * *}$ & $0.01^{* * *}$ \\
$R_{t-1}$ & $(3.64)$ & $(2.91)$ & $(2.73)$ & $(2.94)$ & $(2.93)$ \\
& & $0.01^{* * *}$ & $0.01^{* * *}$ & $0.01^{* * *}$ & $0.01^{* * *}$ \\
$R_{t-2}$ & & $(4.04)$ & $(3.90)$ & $(4.12)$ & $(4.17)$ \\
& & & 0.00 & 0.00 & 0.00 \\
$R_{t-3}$ & & & $(0.63)$ & $(0.82)$ & $(0.93)$ \\
& & & & -0.00 & -0.00 \\
$R_{t-4}$ & & & & $(-1.59)$ & $(-1.50)$ \\
& & & & & -0.00 \\
& & & & & $(-0.68)$ \\
R-Squared & 0.03 & 0.07 & 0.07 & 0.08 & 0.098 \\
\hline
\end{tabular}


Table 26: Twitter

Twitter post count for "Bitcoin" minus the average of previous four weeks, normalized.

\begin{tabular}{lccccccc}
\hline Weekly & $R_{t+1}$ & $R_{t+2}$ & $R_{t+3}$ & $R_{t+4}$ & $R_{t+5}$ & $R_{t+6}$ & $R_{t+7}$ \\
& $(1)$ & $(2)$ & $(3)$ & $(4)$ & $(5)$ & $(6)$ & $(7)$ \\
\hline & & & & & & & \\
Twitter $_{t}$ & $2.50^{* * *}$ & 0.56 & $1.91^{* *}$ & 0.75 & -0.51 & -0.37 & $-1.42^{*}$ \\
& $(2.96)$ & $(0.56)$ & $(2.33)$ & $(0.91)$ & $(-0.62)$ & $(-0.45)$ & $(-1.71)$ \\
& {$[4.07]$} & {$[0.38]$} & {$[2.22]$} & {$[0.74]$} & {$[-0.46]$} & {$[-0.44]$} & {$[-2.83]$} \\
R-Squared & 0.02 & 0.00 & 0.01 & 0.00 & 0.00 & 0.00 & 0.01 \\
\hline
\end{tabular}

Table 27: Twitter by Groups

\begin{tabular}{|c|c|c|c|c|c|c|c|}
\hline \multicolumn{8}{|c|}{ Weekly Level (Percentage) } \\
\hline Rank & Twitter & $R_{t+1}$ & T-Statistics & Sharpe & $R_{t+2}$ & T-Statistics & Sharpe \\
\hline Low & -0.80 & -1.20 & -1.07 & -0.12 & -0.39 & -0.34 & -0.04 \\
\hline 2 & -0.10 & 0.96 & 0.71 & 0.08 & $2.39^{* *}$ & 2.07 & 0.24 \\
\hline 3 & -0.04 & $6.72^{* *}$ & 2.42 & 0.28 & $4.87^{* *}$ & 2.03 & 0.23 \\
\hline 4 & 0.05 & $6.83^{* * *}$ & 4.17 & 0.48 & $8.37^{* * *}$ & 3.66 & 0.42 \\
\hline 5 & 0.91 & $5.33^{* *}$ & 2.60 & 0.30 & 2.15 & 1.25 & 0.14 \\
\hline Difference & & 6.53 & & & 2.54 & & \\
\hline Rank & Twitter & $R_{t+3}$ & T-Statistics & Sharpe & $R_{t+4}$ & T-Statistics & Sharpe \\
\hline Low & -0.80 & -1.24 & -0.95 & -0.11 & -0.29 & -0.25 & -0.03 \\
\hline 2 & -0.10 & 1.92 & 1.20 & 0.14 & $3.15^{*}$ & 1.78 & 0.20 \\
\hline 3 & -0.04 & $6.92^{* * *}$ & 2.90 & 0.33 & $6.79^{* *}$ & 2.54 & 0.29 \\
\hline 4 & 0.05 & $6.52^{* * *}$ & 3.19 & 0.36 & $5.53^{* * *}$ & 3.47 & 0.40 \\
\hline 5 & 0.91 & $3.05^{*}$ & 1.97 & 0.23 & 2.28 & 1.42 & 0.16 \\
\hline Difference & & 4.29 & & & 2.57 & & \\
\hline
\end{tabular}

\subsection{Negative Investor Attention}

We have shown that unconditionally investor attention positively predicts cryptocurrency returns. In this section, we further investigate whether negative investor attention predicts cryptocurrency returns. We construct a ratio between Google searches for the phrase "Bitcoin hack" and searches for the word "Bitcoin" to proxy for negative investor attention. Table 28 shows the results of the predictive regressions. The ratio negatively and significantly predicts 1-5 week Bitcoin retruns. For example, a one-standard-devation increase of the ratio leads to a 2.75 percent decrease of Bitcoin returns in next week. 
Table 28: Bitcoin Hack

The ratio between google searches for the phrase "Bitcoin hack" and searches for the word "Bitcoin", normalized.

\begin{tabular}{|c|c|c|c|c|c|c|c|}
\hline Weekly & $\begin{array}{c}R_{t+1} \\
(1)\end{array}$ & $\begin{array}{c}R_{t+2} \\
(2)\end{array}$ & $\begin{array}{c}R_{t+3} \\
(3)\end{array}$ & $\begin{array}{c}R_{t+4} \\
(4)\end{array}$ & $\begin{array}{l}R_{t+5} \\
(5)\end{array}$ & $\begin{array}{c}R_{t+6} \\
(6)\end{array}$ & $\begin{array}{c}R_{t+7} \\
(7) \\
\end{array}$ \\
\hline Hack $_{t}$ & $\begin{array}{c}-2.75^{* * *} \\
(-3.30)\end{array}$ & $\begin{array}{c}-2.26^{* * *} \\
(-2.70)\end{array}$ & $\begin{array}{l}-1.86^{* *} \\
(-2.20)\end{array}$ & $\begin{array}{l}-1.54^{*} \\
(-1.82)\end{array}$ & $\begin{array}{l}-2.18^{* *} \\
(-2.58)\end{array}$ & $\begin{array}{l}-1.18 \\
(-1.43)\end{array}$ & $\begin{array}{c}-0.96 \\
(-1.16)\end{array}$ \\
\hline & {$[-3.53]$} & {$[-2.52]$} & {$[-2.01]$} & {$[-1.85]$} & {$[-2.58]$} & {$[-1.38]$} & {$[-0.88]$} \\
\hline R-Squared & 0.03 & 0.02 & 0.01 & 0.01 & 0.02 & 0.01 & 0.00 \\
\hline
\end{tabular}

Table 29: Bitcoin Hack by Groups

\begin{tabular}{lccccccc}
\hline \multicolumn{2}{l}{ Weekly Level (Percentage) } & \multicolumn{7}{l}{} \\
\hline Rank & Hack & $R_{t+1}$ & T-Statistics & Sharpe & $R_{t+2}$ & T-Statistics & Sharpe \\
\hline Low & -1.21 & $8.62^{* * *}$ & 2.91 & 0.33 & $8.18^{* * *}$ & 3.17 & 0.36 \\
2 & -0.65 & $5.59^{* * *}$ & 2.69 & 0.30 & $4.23^{*}$ & 1.76 & 0.20 \\
3 & -0.11 & 2.36 & 1.54 & 0.18 & 2.16 & 1.26 & 0.15 \\
4 & 0.49 & 1.14 & 1.28 & 0.14 & $3.09^{* * *}$ & 3.13 & 0.35 \\
5 & 1.54 & 1.09 & 1.11 & 0.13 & 1.09 & 1.11 & 0.13 \\
\hline Difference & & -7.52 & & & -7.09 & & \\
\hline \hline Rank & Hack & $R_{t+3}$ & T-Statistics & Sharpe & $R_{t+4}$ & T-Statistics & Sharpe \\
\hline Low & -1.21 & $7.64^{* * *}$ & 2.95 & 0.33 & $6.08^{* *}$ & 2.10 & 0.24 \\
2 & -0.65 & 3.49 & 1.60 & 0.18 & $4.85^{* *}$ & 2.55 & 0.29 \\
3 & -0.11 & $4.00^{*}$ & 1.93 & 0.22 & $4.00^{* *}$ & 2.19 & 0.25 \\
4 & 0.49 & $1.86^{*}$ & 1.76 & 0.20 & 1.86 & 1.43 & 0.16 \\
5 & 1.54 & $1.70^{*}$ & 1.85 & 0.21 & $1.75^{*}$ & 1.86 & 0.21 \\
\hline Difference & & -5.95 & & & -4.33 & & \\
\hline
\end{tabular}

\subsection{Crypto Price-to-"Dividend" and Crypto Volatility}

Obviously, there is no direct measure of dividend for the cryptocurrencies. However, in its essence, the price-to-dividend ratio is a measure of the gap between the market value and the fundamental value of an asset. The market value of cryptocurrency is just the observed price. We proxy the fundamental value by using the number of Bitcoin Wallet users. We regress the Bitcoin returns on the lagged Bitcoin price-to"dividend" ratio and the results are reported in Table 30. Overall, there is very weak relation between the future Bitcoin returns and the current price-to-"dividend" ratio. For Ripple and Ethereum, the data on the number of users is not immediately available.

Table 30: Bitcoin Market Price-to-"Dividend" Ratio

Predictive regression at the daily level

\begin{tabular}{lccccccc}
\hline Bitcoin & $R_{t+1}$ & $R_{t+2}$ & $R_{t+3}$ & $R_{t+4}$ & $R_{t+5}$ & $R_{t+6}$ & $R_{t+7}$ \\
& $(1)$ & $(2)$ & $(3)$ & $(4)$ & $(5)$ & $(6)$ & $(7)$ \\
\hline \multirow{3}{*}{ Bitcoin PD } & 0.13 & 0.05 & -0.13 & -0.12 & 0.05 & 0.09 & 0.05 \\
& $(1.34)$ & $(0.49)$ & $(-1.36)$ & $(-1.25)$ & $(0.57)$ & $(0.99)$ & $(0.55)$ \\
R-Squared & 0.00 & 0.00 & 0.00 & 0.00 & 0.00 & 0.00 & 0.00 \\
\hline
\end{tabular}


We also investigate whether realized volatility predicts cryptocurrency returns. We regress cryptocurrency returns for the past month realized return volatility and the results are reported in Table 31. Overall, there is very weak relation between future cryptocurrency returns and the realized volatility for Bitcoin and Ethereum. For Ripple, there is some evidence that realized volatility positively predicts 4-day, 5-day, and 7-day ahead Ripple returns.

Table 31: Market Volatility as Predictor

Predictive regressions are at the daily level.

\begin{tabular}{lccccccc}
\hline Bitcoin & $R_{t+1}$ & $R_{t+2}$ & $R_{t+3}$ & $R_{t+4}$ & $R_{t+5}$ & $R_{t+6}$ \\
$(1)$ & $(2)$ & $(3)$ & $(4)$ & $\begin{array}{c}R_{t+7} \\
(7)\end{array}$ \\
\hline \multirow{3}{*}{ Bitcoin Volatility } & 1.27 & 0.79 & 0.57 & 0.03 & 0.02 & -0.21 & -0.15 \\
& $(1.52)$ & $(0.95)$ & $(0.69)$ & $(0.03)$ & $(0.03)$ & $(-0.25)$ & $(-0.18)$ \\
& {$[0.79]$} & {$[0.50]$} & {$[0.38]$} & {$[0.02]$} & {$[0.01]$} & {$[-0.18]$} & {$[-0.11]$} \\
R-Squared & 0.00 & 0.00 & 0.00 & 0.00 & 0.00 & 0.00 & 0.00 \\
\hline Ripple & $R_{t+1}$ & $R_{t+2}$ & $R_{t+3}$ & $R_{t+4}$ & $R_{t+5}$ & $R_{t+6}$ & $R_{t+7}$ \\
& $(1)$ & $(2)$ & $(3)$ & $(4)$ & $(5)$ & $(6)$ & $(7)$ \\
\hline \multirow{3}{*}{ Ripple Volatility } & 0.62 & 0.97 & 0.87 & $1.14^{*}$ & $1.05^{*}$ & 0.99 & $1.22^{* *}$ \\
& $(1.03)$ & $(1.61)$ & $(1.45)$ & $(1.90)$ & $(1.75)$ & $(1.65)$ & $(2.03)$ \\
& {$[0.61]$} & {$[1.43]$} & {$[1.37]$} & {$[1.37]$} & {$[1.13]$} & {$[1.13]$} & {$[1.63]$} \\
R-Squared & 0.00 & 0.00 & 0.00 & 0.00 & 0.00 & 0.00 & 0.00 \\
\hline Ethereum & $R_{t+1}$ & $R_{t+2}$ & $R_{t+3}$ & $R_{t+4}$ & $R_{t+5}$ & $R_{t+6}$ & $R_{t+7}$ \\
& $(1)$ & $(2)$ & $(3)$ & $(4)$ & $(5)$ & $(6)$ & $(7)$ \\
\hline \multirow{3}{*}{ Ethereum Volatility } & & & & & & & \\
& 1.89 & 1.51 & 0.58 & 0.20 & -0.08 & 0.22 & -0.30 \\
& $(0.94)$ & $(0.75)$ & $(0.29)$ & $(0.10)$ & $(-0.04)$ & $(0.11)$ & $(-0.15)$ \\
R-Squared & {$[0.89]$} & {$[0.76]$} & {$[0.26]$} & {$[0.09]$} & {$[-0.04]$} & {$[0.14]$} & {$[-0.15]$} \\
& 0.00 & 0.00 & 0.00 & 0.00 & 0.00 & 0.00 & 0.00 \\
\hline
\end{tabular}

\subsection{Supply Factors}

We now construct proxies for the supply factors. To the first approximation, mining a cryptocurrency requires two inputs: electricity and computer power. For electricity, we consider three proxies: (1) the valueweighted stock returns of the U.S.-listed electricity industries, (2) the value-weighted stock returns of the China-listed electricity industries, and (3) the Sinopec (SNP) stock returns. The reason why we include the China proxies is because electricity supply is location specific and because China is considered to have the largest coin mining operation among all countries. ${ }^{13}$ For proxies of computer power, we consider the stock returns of the companies that are major manufacturers of either GPU mining chips (Nvidia Corporation and Advanced Micro Devices, Inc) or ASIC mining chips (Taiwan Semiconductor Manufacturing Company, Limited and Advanced Semiconductor Engineering, Inc). ${ }^{14}$ Table 32 presents the results for the three

\footnotetext{
${ }^{13}$ See http://www.businessinsider.com/why-china-mines-more-bitcoin-than-any-other-country-2017-12.

${ }^{14}$ See https://www.benzinga.com/markets/cryptocurrency/18/02/11117719/the-companies-behind-the-chips-that-powercryptocurrency-minin.
} 
cryptocurrencies. Somewhat surprisingly, the Bitcoin and Ripple returns are not statistically significantly exposed to any of these supply factors proxies. There is some evidence that Ethereum returns are exposed to the AMD stock returns. We also consider the possibility that the supply factors are more important in the recent periods as mining becomes costlier with the increase in popularity of the cryptocurrencies, but we find no support for this hypothesis (See Appendix).

Table 32: Cryptocurrency Return Loadings to Supply Proxies

\begin{tabular}{|c|c|c|c|c|c|c|c|}
\hline \multicolumn{8}{|c|}{ Panel A: Bitcoin } \\
\hline (Percentage) & (1) & (2) & (3) & (4) & $(5)$ & (6) & (7) \\
\hline \multirow[t]{3}{*}{ ALPHA } & $0.19^{* *}$ & $0.19^{*}$ & $0.20 * *$ & $0.20 * *$ & $0.21^{* *}$ & $0.20 * *$ & $0.20^{* *}$ \\
\hline & $(2.28)$ & $(2.09)$ & $(2.37)$ & $(2.37)$ & $(2.50)$ & $(2.42)$ & $(2.45)$ \\
\hline & {$[2.65]$} & {$[2.27]$} & {$[2.93]$} & {$[2.93]$} & {$[2.79]$} & {$[3.06]$} & {$[2.94]$} \\
\hline \multirow[t]{3}{*}{ U.S. Elec } & 1.33 & & & & & & \\
\hline & $(0.56)$ & & & & & & \\
\hline & {$[0.65]$} & & & & & & \\
\hline \multirow[t]{3}{*}{ China Elec } & & -0.48 & & & & & \\
\hline & & $(-0.79)$ & & & & & \\
\hline & & {$[-1.27]$} & & & & & \\
\hline \multirow[t]{3}{*}{ NVIDIA } & & & 0.04 & & & & \\
\hline & & & $(0.05)$ & & & & \\
\hline & & & {$[0.08]$} & & & & \\
\hline \multirow[t]{3}{*}{ AMD } & & & & -0.30 & & & \\
\hline & & & & $(-0.52)$ & & & \\
\hline & & & & {$[-1.00]$} & & & \\
\hline \multirow[t]{3}{*}{ TSMC } & & & & & -0.96 & & \\
\hline & & & & & $(-0.58)$ & & \\
\hline & & & & & {$[-0.40]$} & & \\
\hline \multirow[t]{3}{*}{$\operatorname{ASX}$} & & & & & & 0.16 & \\
\hline & & & & & & $(0.14)$ & \\
\hline & & & & & & {$[-0.20]$} & \\
\hline \multirow[t]{3}{*}{ SNP } & & & & & & & 0.51 \\
\hline & & & & & & & $(0.42)$ \\
\hline & & & & & & & {$[0.52]$} \\
\hline \multirow[t]{3}{*}{ MKTRF } & 3.14 & 4.38 & 3.43 & 4.23 & 4.22 & 3.38 & 3.09 \\
\hline & $(1.26)$ & $(1.54)$ & $(1.30)$ & $(1.50)$ & $(1.54)$ & $(1.33)$ & (1.19) \\
\hline & {$[1.29]$} & {$[1.67]$} & [1.39] & {$[1.73]$} & {$[1.34]$} & {$[1.60]$} & {$[1.42]$} \\
\hline R-Squared & 0.03 & 0.02 & 0.02 & 0.03 & 0.03 & 0.03 & 0.03 \\
\hline
\end{tabular}




\begin{tabular}{|c|c|c|c|c|c|c|c|c|c|c|c|c|c|c|c|}
\hline \multicolumn{8}{|c|}{ Panel B: Ripple } & \multicolumn{8}{|c|}{ Panel C: Ethereum } \\
\hline (Percentage) & $(1)$ & $(2)$ & (3) & $(4)$ & $(5)$ & $(6)$ & $(7)$ & (Percentage) & (1) & $(2)$ & (3) & $(4)$ & $(5)$ & $(6)$ & (7) \\
\hline \multirow[t]{3}{*}{ ALPHA } & $0.47^{* *}$ & 0.12 & 0.41 & $0.41^{*}$ & $0.44^{*}$ & $0.41^{*}$ & $0.43^{*}$ & ALPHA & $0.32^{* *}$ & 0.12 & $0.36^{* *}$ & $0.44^{* * *}$ & $0.30^{* *}$ & $0.35^{* *}$ & $0.39^{* *}$ \\
\hline & $(2.11)$ & $(0.78)$ & $(1.68)$ & $(1.84)$ & $(1.91)$ & $(1.84)$ & $(1.91)$ & & $(2.23)$ & $(0.73)$ & $(2.11)$ & $(3.15)$ & $(2.08)$ & $(2.46)$ & $(2.76)$ \\
\hline & {$[2.19]$} & {$[0.95]$} & {$[1.69]$} & {$[2.19]$} & {$[2.24]$} & {$[2.28]$} & {$[2.29]$} & & {$[2.38]$} & {$[0.88]$} & {$[2.22]$} & {$[3.32]$} & {$[2.41]$} & {$[2.80]$} & {$[2.64]$} \\
\hline \multirow[t]{3}{*}{ U.S. Elec } & -9.27 & & & & & & & U.S. Elec & 5.09 & & & & & & \\
\hline & $(-1.60)$ & & & & & & & & $(1.37)$ & & & & & & \\
\hline & {$[-1.17]$} & & & & & & & & {$[1.38]$} & & & & & & \\
\hline \multirow[t]{3}{*}{ China Elec } & & 0.23 & & & & & & China Elec & & -4.12 & & & & & \\
\hline & & $(0.13)$ & & & & & & & & $(-1.51)$ & & & & & \\
\hline & & {$[0.25]$} & & & & & & & & {$[-1.17]$} & & & & & \\
\hline \multirow[t]{3}{*}{ NVIDIA } & & & -0.02 & & & & & NVIDIA & & & -0.00 & & & & \\
\hline & & & $(-0.01)$ & & & & & & & & $(-0.00)$ & & & & \\
\hline & & & {$[-0.01]$} & & & & & & & & {$[-0.00]$} & & & & \\
\hline \multirow[t]{3}{*}{ AMD } & & & & -1.76 & & & & AMD & & & & $-1.80^{*}$ & & & \\
\hline & & & & $(-1.10)$ & & & & & & & & $(-1.96)$ & & & \\
\hline & & & & {$[-1.62]$} & & & & & & & & {$[-2.00]$} & & & \\
\hline \multirow[t]{3}{*}{ TSMC } & & & & & -2.84 & & & TSMC & & & & & 3.49 & & \\
\hline & & & & & $(-0.64)$ & & & & & & & & $(1.36)$ & & \\
\hline & & & & & {$[-0.62]$} & & & & & & & & {$[1.56]$} & & \\
\hline \multirow[t]{3}{*}{ ASX } & & & & & & -1.20 & & ASX & & & & & & 1.77 & \\
\hline & & & & & & $(-0.36)$ & & & & & & & & $(0.80)$ & \\
\hline & & & & & & {$[-0.73]$} & & & & & & & & {$[0.84]$} & \\
\hline \multirow[t]{3}{*}{ SNP } & & & & & & & 3.00 & SNP & & & & & & & 2.88 \\
\hline & & & & & & & $(0.86)$ & & & & & & & & (1.18) \\
\hline & & & & & & & [1.38] & & & & & & & & [1.04] \\
\hline \multirow[t]{3}{*}{ MKTRF } & 4.08 & 2.28 & 1.45 & 6.20 & 3.70 & 2.18 & -2.33 & MKTRF & -1.46 & 9.52 & -0.36 & 5.09 & -2.45 & -1.07 & -4.15 \\
\hline & $(0.55)$ & $(0.44)$ & $(0.18)$ & $(0.73)$ & $(0.45)$ & $(0.28)$ & $(-0.27)$ & & $(-0.33)$ & $(1.31)$ & $(-0.08)$ & $(1.01)$ & $(-0.53)$ & $(-0.23)$ & $(-0.76)$ \\
\hline & {$[0.77]$} & {$[0.79]$} & {$[0.23]$} & {$[1.40]$} & {$[0.56]$} & {$[0.52]$} & {$[-0.55]$} & & {$[-0.40]$} & {$[1.56]$} & {$[-0.08]$} & {$[1.01]$} & {$[-0.58]$} & {$[-0.24]$} & {$[-0.82]$} \\
\hline R-Squared & 0.05 & 0.01 & 0.00 & 0.02 & 0.01 & 0.00 & 0.02 & R-Squared & 0.07 & 0.14 & 0.00 & 0.13 & 0.07 & 0.02 & 0.05 \\
\hline
\end{tabular}




\section{Industry Exposures to Bitcoin Risk}

In this section, we first estimate the exposures of the Fama French 30 industry groups to the cryptocurrency risk. Second, we continue with a finer industry classification and investigate the cryptocurrency risk exposures of 354 SIC industries in the US and 137 CIC industries in China. These exposures which can be thought of as an index indicating the potential winners and losers from the current and future development of blockchain. Throughout this section, t-statistics in parentheses and brackets are based on regular and bootstrapped standard errors.

\subsection{Estimating Broad Industry Exposures}

Table 33: Industry Exposure to Bitcoin Return

\begin{tabular}{|c|c|c|c|c|c|c|c|c|c|c|}
\hline $\mathrm{x} 100$ & food & beer & smoke & games & books & hshld & clths & hlth & chems & txtls \\
\hline \multirow[t]{3}{*}{ BITCOIN } & 0.56 & 0.52 & -0.27 & -0.03 & -0.61 & $0.71^{*}$ & 0.69 & $0.64^{*}$ & -0.40 & 0.20 \\
\hline & (1.63) & $(1.23)$ & $(-0.39)$ & $(-0.06)$ & $(-1.35)$ & $(1.87)$ & (1.16) & $(1.81)$ & $(-1.06)$ & $(0.36)$ \\
\hline & {$[1.23]$} & {$[0.98]$} & {$[-0.38]$} & {$[-0.08]$} & {$[-1.49]$} & {$[2.29]$} & {$[1.17]$} & {$[2.03]$} & {$[-1.08]$} & {$[0.51]$} \\
\hline \multirow[t]{3}{*}{ MKTRF } & $0.59^{* * *}$ & $0.39 * * *$ & $0.59^{* * *}$ & $1.36^{* * *}$ & $1.26^{* * *}$ & $0.56^{* * *}$ & $0.74^{* * *}$ & $0.84^{* * *}$ & $1.39^{* * *}$ & $1.20^{* * *}$ \\
\hline & $(8.04)$ & $(4.32)$ & $(3.96)$ & $(10.62)$ & $(12.85)$ & $(6.85)$ & $(5.79)$ & $(11.07)$ & $(17.01)$ & (10.09) \\
\hline & {$[8.60]$} & {$[4.41]$} & {$[4.38]$} & {$[11.52]$} & [14.35] & {$[5.65]$} & {$[4.97]$} & {$[9.15]$} & [14.33] & {$[9.29]$} \\
\hline \multirow[t]{3}{*}{ ALPHA } & 0.06 & $0.53^{*}$ & 0.59 & 0.11 & -0.39 & -0.12 & 0.25 & 0.21 & -0.33 & 0.11 \\
\hline & $(0.24)$ & $(1.69)$ & $(1.14)$ & $(0.25)$ & $(-1.16)$ & $(-0.42)$ & $(0.56)$ & $(0.81)$ & $(-1.15)$ & $(0.28)$ \\
\hline & {$[0.22]$} & {$[1.52]$} & {$[1.14]$} & {$[0.20]$} & {$[-1.31]$} & {$[-0.44]$} & {$[0.58]$} & {$[0.65]$} & {$[-1.01]$} & {$[0.26]$} \\
\hline R-Squared & 0.46 & 0.21 & 0.16 & 0.58 & 0.66 & 0.40 & 0.32 & 0.61 & 0.77 & 0.55 \\
\hline $\mathrm{x} 100$ & cnstr & steel & fabpr & elceq & autos & carry & mines & coal & oil & util \\
\hline \multirow[t]{3}{*}{ BITCOIN } & -0.62 & -0.67 & $-0.95^{* *}$ & -0.61 & -0.77 & 0.26 & $-1.65^{*}$ & -1.53 & -0.45 & 0.18 \\
\hline & $(-1.39)$ & $(-0.95)$ & $(-2.02)$ & $(-1.46)$ & $(-1.42)$ & $(0.72)$ & $(-1.69)$ & $(-0.85)$ & $(-0.71)$ & $(0.37)$ \\
\hline & {$[-1.50]$} & {$[-1.72]$} & {$[-2.34]$} & {$[-1.43]$} & {$[-1.51]$} & {$[1.02]$} & {$[-2.10]$} & {$[-1.87]$} & {$[-1.18]$} & {$[0.30]$} \\
\hline \multirow[t]{3}{*}{ MKTRF } & $1.47^{* * *}$ & $1.64^{* * *}$ & $1.46^{* * *}$ & $1.31^{* * *}$ & $1.50^{* * *}$ & $1.03^{* * *}$ & $1.28^{* * *}$ & $1.72^{* * *}$ & $1.22^{* * *}$ & $0.31^{* * *}$ \\
\hline & $(15.37)$ & $(10.75)$ & $(14.47)$ & $(14.48)$ & $(12.73)$ & $(12.97)$ & $(6.03)$ & $(4.43)$ & $(9.02)$ & $(3.04)$ \\
\hline & {$[12.17]$} & {$[12.00]$} & [11.09] & {$[14.75]$} & {$[9.62]$} & {$[12.12]$} & {$[5.92]$} & {$[3.54]$} & {$[11.11]$} & {$[3.12]$} \\
\hline \multirow[t]{3}{*}{ ALPHA } & -0.37 & $-1.17^{* *}$ & -0.35 & $-0.65^{* *}$ & $-0.73^{*}$ & 0.34 & -1.06 & $-3.19 * *$ & -0.76 & 0.48 \\
\hline & $(-1.11)$ & $(-2.22)$ & $(-1.00)$ & $(-2.08)$ & $(-1.80)$ & $(1.23)$ & $(-1.44)$ & $(-2.37)$ & $(-1.63)$ & (1.35) \\
\hline & {$[-0.99]$} & {$[-2.49]$} & {$[-0.81]$} & {$[-2.13]$} & {$[-1.79]$} & {$[1.17]$} & {$[-1.24]$} & {$[-2.04]$} & {$[-1.47]$} & {$[1.48]$} \\
\hline R-Squared & 0.74 & 0.58 & 0.71 & 0.71 & 0.66 & 0.67 & 0.30 & 0.19 & 0.49 & 0.10 \\
\hline x100 & telcm & servs & buseq & paper & trans & whlsl & rtail & meals & fin & other \\
\hline \multirow[t]{3}{*}{ BITCOIN } & 0.19 & -0.18 & -0.05 & 0.22 & 0.29 & 0.14 & 0.18 & 0.30 & -0.11 & -0.16 \\
\hline & $(0.51)$ & $(-0.61)$ & $(-0.13)$ & $(0.84)$ & $(0.70)$ & $(0.46)$ & $(0.54)$ & $(0.89)$ & $(-0.34)$ & $(-0.50)$ \\
\hline & {$[0.43]$} & {$[-1.08]$} & {$[-0.19]$} & {$[0.81]$} & {$[1.05]$} & {$[0.66]$} & {$[0.62]$} & {$[0.87]$} & {$[-0.28]$} & {$[-0.87]$} \\
\hline \multirow[t]{3}{*}{ MKTRF } & $0.85^{* * *}$ & $1.02^{* * *}$ & $1.10^{* * *}$ & $1.08^{* * *}$ & $1.00^{* * *}$ & $1.02^{* * *}$ & $0.85^{* * *}$ & $0.69^{* * *}$ & $1.24^{* * *}$ & $0.86^{* * *}$ \\
\hline & $(10.71)$ & (16.15) & (13.08) & $(18.76)$ & (10.98) & (15.93) & (11.98) & $(9.46)$ & $(17.65)$ & (12.54) \\
\hline & {$[10.88]$} & {$[16.31]$} & {$[14.15]$} & {$[25.57]$} & {$[9.79]$} & {$[14.14]$} & {$[13.24]$} & {$[9.79]$} & {$[21.63]$} & [13.75] \\
\hline \multirow[t]{3}{*}{ ALPHA } & 0.00 & 0.27 & 0.07 & -0.18 & 0.03 & -0.16 & 0.37 & $0.44^{*}$ & -0.06 & 0.10 \\
\hline & $(0.01)$ & $(1.26)$ & $(0.26)$ & $(-0.91)$ & $(0.09)$ & $(-0.73)$ & $(1.50)$ & $(1.75)$ & $(-0.23)$ & $(0.43)$ \\
\hline & {$[-0.07]$} & {$[1.16]$} & {$[0.18]$} & {$[-0.88]$} & {$[0.03]$} & {$[-0.69]$} & {$[1.20]$} & {$[1.49]$} & {$[-0.28]$} & {$[0.36]$} \\
\hline R-Squared & 0.58 & 0.76 & 0.67 & 0.81 & 0.60 & 0.76 & 0.64 & 0.53 & 0.79 & 0.65 \\
\hline
\end{tabular}

Table 33 reports the Fama French 30 industries' exposures on Bitcoin returns controlling for the excess market returns. Specifically, we regress each industry's stock returns on the contemporaneous Bitcoin returns 
and the excess stock market returns. The Consumer Goods (Hshld) and Healthcare (Hlth) industries are positively and statistically significantly affected while the Fabricated Products (FabPr) and Metal Mining (Mines) industries are negatively and statistically significantly affected. These point estimates state that a one-standard-deviation increase in Bitcoin returns is associated with the 0.49 percent increase in the return of the Consumer Goods industry, 0.44 percent increase in the return of the Healthcare industry, 0.66 percent decrease in the return of the Fabricated Products industry, and 1.15 percent decrease in the return of the Metal Mining. Surprisingly, the often mentioned Finance, Retail, and Wholesale industries have no statistically significant exposure, and the magnitude of the point estimates is very small.

Table 34: Industry Exposure to Ripple Returns

\begin{tabular}{|c|c|c|c|c|c|c|c|c|c|c|}
\hline \multicolumn{11}{|c|}{ Panel A: Ripple Return } \\
\hline $\mathrm{x} 100$ & food & beer & smoke & games & books & hshld & clths & hlth & chems & txtls \\
\hline \multirow[t]{3}{*}{ RIPPLE } & -0.06 & 0.26 & 0.13 & -0.02 & -0.24 & 0.30 & 0.41 & -0.07 & -0.14 & -0.03 \\
\hline & $(-0.28)$ & $(1.01)$ & $(0.30)$ & $(-0.07)$ & $(-0.90)$ & $(1.30)$ & $(1.29)$ & $(-0.33)$ & $(-0.60)$ & $(-0.09)$ \\
\hline & {$[-0.45]$} & {$[0.86]$} & {$[0.24]$} & {$[-0.06]$} & {$[-1.00]$} & {$[1.33]$} & {$[1.31]$} & {$[-0.43]$} & {$[-0.53]$} & {$[-0.07]$} \\
\hline \multirow[t]{3}{*}{ MKTRF } & $0.70^{* * *}$ & $0.54^{* * *}$ & $0.59^{* * *}$ & $1.19^{* * *}$ & $1.38^{* * *}$ & $0.62^{* * *}$ & $0.64^{* * *}$ & $0.99^{* * *}$ & $1.31^{* * *}$ & $1.08^{* * *}$ \\
\hline & $(6.59)$ & $(4.26)$ & $(2.77)$ & $(6.79)$ & $(10.50)$ & $(5.33)$ & $(4.10)$ & $(8.99)$ & $(11.42)$ & $(6.55)$ \\
\hline & {$[5.91]$} & {$[3.93]$} & {$[2.66]$} & {$[5.90]$} & {$[10.76]$} & {$[4.04]$} & {$[5.29]$} & {$[7.47]$} & {$[12.26]$} & {$[6.58]$} \\
\hline \multirow[t]{3}{*}{ ALPHA } & -0.09 & 0.31 & 0.19 & 0.49 & $-0.78^{*}$ & -0.41 & 0.19 & -0.01 & -0.20 & -0.20 \\
\hline & $(-0.27)$ & $(0.78)$ & $(0.28)$ & $(0.88)$ & $(-1.89)$ & $(-1.10)$ & $(0.39)$ & $(-0.03)$ & $(-0.56)$ & $(-0.39)$ \\
\hline & {$[-0.38]$} & {$[0.65]$} & {$[0.25]$} & {$[0.85]$} & {$[-2.60]$} & {$[-1.14]$} & {$[0.29]$} & {$[-0.09]$} & {$[-0.63]$} & {$[-0.44]$} \\
\hline R-Squared & 0.4456 & 0.2653 & 0.1262 & 0.4606 & 0.6718 & 0.3614 & 0.2588 & 0.5993 & 0.7074 & 0.4427 \\
\hline $\mathrm{x} 100$ & cnstr & steel & fabpr & elceq & autos & carry & mines & coal & oil & util \\
\hline \multirow[t]{3}{*}{ RIPPLE } & -0.01 & 0.32 & 0.06 & 0.14 & -0.14 & 0.20 & 0.12 & 0.49 & -0.06 & $-0.50^{*}$ \\
\hline & $(-0.06)$ & $(0.69)$ & $(0.22)$ & $(0.65)$ & $(-0.54)$ & $(0.87)$ & $(0.20)$ & $(0.42)$ & $(-0.13)$ & $(-1.69)$ \\
\hline & {$[-0.06]$} & {$[0.38]$} & {$[0.21]$} & {$[0.74]$} & {$[-0.37]$} & [0.99] & {$[0.12]$} & {$[0.38]$} & {$[-0.10]$} & {$[-1.84]$} \\
\hline \multirow[t]{3}{*}{ MKTRF } & $1.32^{* * *}$ & $1.50^{* * *}$ & $1.26^{* * *}$ & $1.24^{* * *}$ & $1.33^{* * *}$ & $1.12^{* * *}$ & $1.04^{* * *}$ & $1.29^{* *}$ & $1.07^{* * *}$ & $0.31^{* *}$ \\
\hline & $(10.43)$ & $(6.51)$ & $(9.33)$ & (11.69) & $(10.61)$ & $(9.80)$ & $(3.48)$ & $(2.20)$ & $(5.03)$ & $(2.13)$ \\
\hline & {$[7.88]$} & {$[6.15]$} & {$[7.97]$} & {$[15.43]$} & {$[9.68]$} & {$[9.40]$} & {$[4.56]$} & {$[1.56]$} & {$[5.25]$} & {$[1.81]$} \\
\hline \multirow[t]{3}{*}{ ALPHA } & -0.40 & -0.70 & -0.22 & $-0.80^{* *}$ & $-0.73^{*}$ & 0.28 & -0.39 & -2.39 & -0.88 & 0.50 \\
\hline & $(-1.01)$ & $(-0.96)$ & $(-0.53)$ & $(-2.41)$ & $(-1.85)$ & $(0.77)$ & $(-0.41)$ & $(-1.30)$ & $(-1.31)$ & $(1.10)$ \\
\hline & {$[-1.00]$} & {$[-1.14]$} & {$[-0.60]$} & {$[-2.60]$} & {$[-1.62]$} & {$[0.73]$} & {$[-0.43]$} & {$[-1.30]$} & {$[-1.45]$} & {$[1.05]$} \\
\hline R-Squared & 0.6683 & 0.4441 & 0.6178 & 0.7183 & 0.6758 & 0.6435 & 0.1841 & 0.0860 & 0.3191 & 0.1177 \\
\hline $\mathrm{x} 100$ & telcm & servs & buseq & paper & trans & whlsl & rtail & meals & fin & other \\
\hline \multirow[t]{3}{*}{ RIPPLE } & 0.12 & 0.02 & -0.05 & -0.01 & 0.26 & 0.26 & 0.24 & $0.35 *$ & -0.06 & -0.11 \\
\hline & $(0.52)$ & $(0.12)$ & $(-0.24)$ & $(-0.05)$ & $(1.01)$ & (1.39) & (1.13) & $(1.86)$ & $(-0.31)$ & $(-0.61)$ \\
\hline & {$[0.37]$} & {$[0.09]$} & {$[-0.23]$} & {$[-0.05]$} & {$[1.04]$} & [0.92] & {$[0.73]$} & {$[0.97]$} & {$[-0.23]$} & {$[-0.60]$} \\
\hline \multirow[t]{3}{*}{ MKTRF } & $0.95^{* * *}$ & $1.01^{* * *}$ & $1.08^{* * *}$ & $1.13^{* * *}$ & $1.05^{* * *}$ & $1.06^{* * *}$ & $1.01^{* * *}$ & $0.77^{* * *}$ & $1.17^{* * *}$ & $0.88^{* * *}$ \\
\hline & $(8.60)$ & $(10.40)$ & $(9.75)$ & (13.65) & $(8.24)$ & (11.39) & $(9.61)$ & $(8.18)$ & $(11.23)$ & $(9.43)$ \\
\hline & {$[8.77]$} & {$[9.55]$} & [11.96] & {$[18.60]$} & {$[6.28]$} & {$[10.42]$} & {$[11.12]$} & {$[8.27]$} & [11.09] & {$[10.06]$} \\
\hline \multirow[t]{3}{*}{ ALPHA } & -0.47 & 0.43 & 0.46 & -0.27 & 0.02 & -0.47 & 0.03 & 0.27 & 0.08 & -0.11 \\
\hline & $(-1.36)$ & $(1.42)$ & $(1.31)$ & $(-1.03)$ & $(0.05)$ & $(-1.60)$ & $(0.09)$ & $(0.91)$ & $(0.23)$ & $(-0.36)$ \\
\hline & {$[-1.33]$} & {$[1.58]$} & [1.19] & {$[-1.31]$} & {$[-0.01]$} & {$[-1.81]$} & {$[0.02]$} & {$[0.78]$} & {$[0.19]$} & {$[-0.50]$} \\
\hline R-Squared & 0.5801 & 0.6675 & 0.6379 & 0.7753 & 0.5628 & 0.7109 & 0.6362 & 0.5692 & 0.7003 & 0.6222 \\
\hline
\end{tabular}




\begin{tabular}{|c|c|c|c|c|c|c|c|c|c|c|}
\hline \multicolumn{11}{|c|}{ Panel B: Same Period Bitcoin Return } \\
\hline $\mathrm{x} 100$ & food & beer & smoke & games & books & hshld & clths & hlth & chems & txtls \\
\hline \multirow[t]{3}{*}{ BITCOIN } & -0.01 & 0.16 & -0.97 & -0.35 & $-1.06^{*}$ & 0.57 & 0.54 & 0.12 & -0.48 & -0.05 \\
\hline & $(-0.01)$ & $(0.28)$ & $(-1.02)$ & $(-0.44)$ & $(-1.83)$ & $(1.08)$ & $(0.76)$ & $(0.24)$ & $(-0.94)$ & $(-0.06)$ \\
\hline & {$[-0.01]$} & {$[0.11]$} & {$[-0.75]$} & {$[-0.23]$} & {$[-0.60]$} & {$[0.64]$} & {$[0.30]$} & {$[0.14]$} & {$[-0.56]$} & {$[-0.03]$} \\
\hline \multirow[t]{3}{*}{ MKTRF } & $0.70^{* * *}$ & $0.54^{* * *}$ & $0.62^{* * *}$ & $1.20^{* * *}$ & $1.41^{* * *}$ & $0.61^{* * *}$ & $0.63^{* * *}$ & $0.98^{* * *}$ & $1.33^{* * *}$ & $1.08^{* * *}$ \\
\hline & $(6.51)$ & $(4.17)$ & $(2.92)$ & $(6.79)$ & (10.87) & $(5.13)$ & $(3.95)$ & $(8.84)$ & (11.48) & $(6.49)$ \\
\hline & {$[5.77]$} & {$[3.96]$} & {$[2.83]$} & {$[5.74]$} & {$[10.56]$} & [3.85] & {$[4.91]$} & [7.13] & {$[12.17]$} & {$[6.25]$} \\
\hline \multirow[t]{3}{*}{ ALPHA } & -0.11 & 0.39 & 0.36 & 0.52 & $-0.73^{*}$ & -0.37 & 0.27 & -0.05 & -0.19 & -0.21 \\
\hline & $(-0.34)$ & $(0.97)$ & $(0.55)$ & $(0.96)$ & $(-1.83)$ & $(-1.00)$ & $(0.55)$ & $(-0.16)$ & $(-0.54)$ & $(-0.41)$ \\
\hline & {$[-0.46]$} & {$[0.79]$} & {$[0.53]$} & {$[0.88]$} & {$[-2.77]$} & {$[-1.06]$} & {$[0.44]$} & {$[-0.23]$} & {$[-0.58]$} & {$[-0.46]$} \\
\hline R-Squared & 0.4448 & 0.2525 & 0.1413 & 0.4625 & 0.6863 & 0.3556 & 0.2442 & 0.5989 & 0.7102 & 0.4426 \\
\hline x100 & cnstr & steel & fabpr & elceq & autos & carry & mines & coal & oil & util \\
\hline \multirow[t]{3}{*}{ BITCOIN } & -0.12 & -0.48 & -0.59 & -0.15 & -0.43 & 0.33 & -1.50 & -1.05 & -0.47 & -0.57 \\
\hline & $(-0.21)$ & $(-0.46)$ & $(-0.99)$ & $(-0.31)$ & $(-0.77)$ & $(0.64)$ & $(-1.13)$ & $(-0.40)$ & $(-0.49)$ & $(-0.85)$ \\
\hline & {$[-0.10]$} & {$[-0.29]$} & {$[-0.60]$} & {$[-0.12]$} & {$[-0.39]$} & {$[0.38]$} & {$[-0.72]$} & {$[-0.31]$} & {$[-0.29]$} & {$[-0.55]$} \\
\hline \multirow[t]{3}{*}{ MKTRF } & $1.33^{* * *}$ & $1.52^{* * *}$ & $1.28^{* * *}$ & $1.25^{* * *}$ & $1.35^{* * *}$ & $1.12^{* * *}$ & $1.09^{* * *}$ & $1.33^{* *}$ & $1.09^{* * *}$ & $0.32^{* *}$ \\
\hline & $(10.35)$ & $(6.51)$ & $(9.46)$ & $(11.60)$ & $(10.62)$ & $(9.60)$ & $(3.65)$ & $(2.25)$ & $(5.06)$ & $(2.14)$ \\
\hline & {$[7.92]$} & {$[6.11]$} & {$[8.21]$} & {$[15.32]$} & {$[9.67]$} & {$[9.29]$} & {$[4.72]$} & {$[1.62]$} & {$[4.91]$} & {$[1.86]$} \\
\hline \multirow[t]{3}{*}{ ALPHA } & -0.39 & -0.52 & -0.13 & $-0.73^{* *}$ & $-0.73^{*}$ & 0.31 & -0.15 & -2.08 & -0.84 & 0.39 \\
\hline & $(-0.99)$ & $(-0.72)$ & $(-0.30)$ & $(-2.21)$ & $(-1.86)$ & $(0.86)$ & $(-0.16)$ & $(-1.14)$ & $(-1.26)$ & $(0.85)$ \\
\hline & {$[-0.95]$} & {$[-0.89]$} & {$[-0.37]$} & {$[-2.28]$} & {$[-1.64]$} & {$[0.81]$} & {$[-0.19]$} & {$[-1.13]$} & {$[-1.36]$} & {$[0.78]$} \\
\hline R-Squared & 0.6686 & 0.4414 & 0.6242 & 0.7166 & 0.6776 & 0.6411 & 0.2024 & 0.0858 & 0.3220 & 0.0831 \\
\hline $\mathrm{x} 100$ & telcm & servs & buseq & paper & trans & whlsl & rtail & meals & fin & other \\
\hline \multirow[t]{3}{*}{ BITCOIN } & -0.37 & 0.05 & 0.19 & 0.17 & 0.46 & 0.10 & 0.03 & 0.36 & 0.36 & -0.32 \\
\hline & $(-0.75)$ & $(0.12)$ & $(0.38)$ & $(0.45)$ & $(0.81)$ & $(0.24)$ & $(0.07)$ & $(0.84)$ & $(0.78)$ & $(-0.76)$ \\
\hline & {$[-0.51]$} & {$[0.06]$} & {$[0.17]$} & {$[0.27]$} & {$[0.71]$} & {$[0.10]$} & {$[0.05]$} & {$[0.35]$} & {$[0.40]$} & {$[-0.40]$} \\
\hline \multirow[t]{3}{*}{ MKTRF } & $0.96^{* * *}$ & $1.01^{* * *}$ & $1.08^{* * *}$ & $1.13^{* * *}$ & $1.04^{* * *}$ & $1.06^{* * *}$ & $1.02^{* * *}$ & $0.76^{* * *}$ & $1.15^{* * *}$ & $0.89^{* * *}$ \\
\hline & $(8.66)$ & $(10.28)$ & $(9.60)$ & $(13.46)$ & $(8.04)$ & (11.09) & $(9.43)$ & $(7.83)$ & (11.05) & $(9.44)$ \\
\hline & {$[9.02]$} & {$[9.24]$} & {$[11.61]$} & {$[18.37]$} & {$[6.18]$} & {$[9.95]$} & [10.98] & {$[8.48]$} & [11.00] & {$[9.79]$} \\
\hline \multirow[t]{3}{*}{ ALPHA } & -0.38 & 0.43 & 0.41 & -0.29 & 0.05 & -0.39 & 0.11 & 0.35 & 0.01 & -0.11 \\
\hline & $(-1.11)$ & $(1.44)$ & $(1.20)$ & $(-1.14)$ & $(0.14)$ & $(-1.31)$ & $(0.34)$ & $(1.17)$ & $(0.02)$ & $(-0.37)$ \\
\hline & {$[-1.14]$} & {$[1.55]$} & {$[1.11]$} & {$[-1.46]$} & {$[0.07]$} & {$[-1.62]$} & {$[0.29]$} & {$[1.10]$} & {$[-0.07]$} & {$[-0.51]$} \\
\hline R-Squared & 0.5824 & 0.6675 & 0.6385 & 0.7762 & 0.5598 & 0.7010 & 0.6277 & 0.5474 & 0.7031 & 0.6237 \\
\hline
\end{tabular}

Table 34 reports the Fama French 30 industries' exposures on the Ripple returns controlling for the excess market returns. The Restaurant, Hotels, Motels (meals) industry is positively and statistically significantly affected while the Utility (util) industry is negatively and statistically significantly affected. We report the Fama French 30 industry exposures to Bitcoin returns for the same time period as well. The only statistically significant point estimate comes from the Printing and Publishing (books, negative) industry. Although the point estimates are not significant, the directions of the estimates are similar to those in the full sample. For example, Consumer Goods and Healthcare industries are positively exposed while Fabricated Products and Metal Mining industries are negatively exposed.

Table 35 reports the Fama French 30 industries' exposures on Ethereum return controlling for the excess market returns. The Restaurant, Hotels, Motels (meals) industry is positively and statistically significantly affected while the Banking, Insurance, Real Estate, Trading (fin) industry is negatively and statistically significantly affected. We report the Fama French 30 industry exposures to Bitcoin returns for the same time period as well. The statistically significant point estimates are the Beer and Liquor (beer, positive) 
and the Restaurant, Hotels, Motels (meals, positive) industries. Again, the signs of the point estimates are similar to those of the full sample.

Table 35: Industry Exposure to Ethereum Returns

\begin{tabular}{|c|c|c|c|c|c|c|c|c|c|c|}
\hline \multicolumn{11}{|c|}{ Panel A: Ethereum Return } \\
\hline $\mathrm{x} 100$ & food & beer & smoke & games & books & hshld & clths & hlth & chems & txtls \\
\hline \multirow[t]{3}{*}{ ETHEREUM } & 0.62 & 0.69 & 1.74 & 1.36 & -0.61 & 0.72 & 0.23 & 0.05 & 0.13 & 0.69 \\
\hline & $(1.02)$ & $(0.86)$ & $(1.39)$ & $(1.34)$ & $(-0.81)$ & $(1.00)$ & $(0.25)$ & $(0.08)$ & $(0.19)$ & $(0.81)$ \\
\hline & {$[1.54)$} & {$[0.85)$} & {$[1.31)$} & {$[1.48)$} & {$[-1.05)$} & {$[1.06)$} & {$[0.42)$} & {$[0.13)$} & {$[0.15)$} & {$[1.11)$} \\
\hline \multirow[t]{3}{*}{ MKTRF } & $0.51^{* * *}$ & $0.44^{* *}$ & 0.34 & $1.32^{* * *}$ & $1.35 * * *$ & $0.47 * * *$ & $0.47^{* *}$ & $1.11^{* * *}$ & $1.43^{* * *}$ & $0.95^{* * *}$ \\
\hline & $(3.79)$ & $(2.46)$ & $(1.22)$ & $(5.95)$ & $(8.14)$ & $(2.97)$ & $(2.29)$ & $(8.08)$ & $(9.12)$ & $(5.09)$ \\
\hline & {$[3.40)$} & {$[2.06)$} & {$[1.00)$} & {$[6.35)$} & {$[7.88)$} & {$[2.48)$} & {$[2.74)$} & {$[8.00)$} & {$[7.15)$} & {$[6.54)$} \\
\hline \multirow[t]{3}{*}{ ALPHA } & -0.42 & 0.06 & -0.43 & 0.28 & -0.83 & -0.49 & -0.03 & -0.79 & -0.17 & $-1.38^{* *}$ \\
\hline & $(-0.90)$ & $(0.10)$ & $(-0.45)$ & $(0.36)$ & $(-1.44)$ & $(-0.88)$ & $(-0.05)$ & $(-1.64)$ & $(-0.32)$ & $(-2.11)$ \\
\hline & {$[-1.27)$} & {$[0.04)$} & {$[-0.65)$} & {$[0.30)$} & {$[-1.61)$} & {$[-1.04)$} & {$[-0.13)$} & {$[-1.67)$} & {$[-0.62)$} & {$[-2.23)$} \\
\hline R-Squared & 0.3491 & 0.1919 & 0.1094 & 0.5626 & 0.6884 & 0.2560 & 0.1531 & 0.6869 & 0.7367 & 0.4767 \\
\hline $\mathrm{x} 100$ & cnstr & steel & fabpr & elceq & autos & carry & mines & coal & oil & util \\
\hline \multirow[t]{3}{*}{ ETHEREUM } & -0.37 & -0.92 & 0.17 & -0.09 & -0.33 & -0.67 & -0.28 & 0.10 & -1.48 & 1.25 \\
\hline & $(-0.45)$ & $(-0.62)$ & $(0.21)$ & $(-0.14)$ & $(-0.43)$ & $(-0.99)$ & $(-0.16)$ & $(0.03)$ & $(-1.22)$ & $(1.52)$ \\
\hline & {$[-0.47)$} & {$[-0.56)$} & {$[0.25)$} & {$[-0.15)$} & {$[-0.35)$} & {$[-0.96)$} & {$[-0.17)$} & {$[0.04)$} & {$[-1.62)$} & {$[1.71)$} \\
\hline \multirow[t]{3}{*}{ MKTRF } & $1.22^{* * *}$ & $1.64^{* * *}$ & $1.25^{* * *}$ & $1.27^{* * *}$ & $1.33^{* * *}$ & $1.17^{* * *}$ & $1.00^{* *}$ & 0.72 & $1.19^{* * *}$ & 0.21 \\
\hline & $(6.79)$ & $(5.06)$ & $(7.20)$ & $(8.67)$ & $(7.93)$ & $(7.85)$ & $(2.72)$ & $(0.91)$ & $(4.47)$ & $(1.15)$ \\
\hline & {$[5.43)$} & {$[4.82)$} & {$[6.18)$} & {$[10.78)$} & {$[7.14)$} & {$[8.74)$} & {$[3.61)$} & {$[0.55)$} & {$[4.95)$} & {$[1.18)$} \\
\hline \multirow[t]{3}{*}{ ALPHA } & 0.01 & 0.33 & 0.45 & -0.63 & -0.65 & $0.95^{*}$ & 0.79 & 0.64 & 0.16 & 0.01 \\
\hline & $(0.01)$ & $(0.29)$ & $(0.74)$ & $(-1.23)$ & $(-1.11)$ & $(1.82)$ & $(0.61)$ & $(0.23)$ & $(0.17)$ & $(0.01)$ \\
\hline & {$[-0.06)$} & {$[0.35)$} & {$[0.68)$} & {$[-1.51)$} & {$[-1.16)$} & {$[1.92)$} & {$[0.58)$} & {$[0.23)$} & {$[0.13)$} & {$[-0.06)$} \\
\hline R-Squared & 0.6057 & 0.4612 & 0.6358 & 0.7155 & 0.6770 & 0.6730 & 0.1980 & 0.0273 & 0.4097 & 0.1154 \\
\hline $\mathrm{x} 100$ & telcm & servs & buseq & paper & trans & whlsl & rtail & meals & fin & other \\
\hline \multirow[t]{3}{*}{ ETHEREUM } & 0.57 & 0.43 & 0.75 & 0.72 & 0.14 & 0.13 & 0.52 & $1.67^{* * *}$ & $-1.76^{* * *}$ & -0.12 \\
\hline & $(0.78)$ & $(0.71)$ & (1.03) & $(1.43)$ & $(0.18)$ & $(0.20)$ & $(0.89)$ & $(2.94)$ & $(-2.95)$ & $(-0.22)$ \\
\hline & {$[0.94)$} & {$[0.89)$} & {$[1.45)$} & {$[1.64)$} & {$[0.14)$} & {$[0.20)$} & {$[1.68)$} & {$[3.11)$} & {$[-4.48)$} & {$[-0.30)$} \\
\hline \multirow[t]{3}{*}{ MKTRF } & $0.91^{* * *}$ & $1.03^{* * *}$ & $1.06^{* * *}$ & $1.09^{* * *}$ & $1.08^{* * *}$ & $1.08^{* * *}$ & $0.95^{* * *}$ & $0.68^{* * *}$ & $1.22^{* * *}$ & $0.82^{* * *}$ \\
\hline & $(5.67)$ & $(7.81)$ & $(6.58)$ & $(9.80)$ & $(5.93)$ & $(7.49)$ & $(7.35)$ & $(5.45)$ & $(9.28)$ & $(6.87)$ \\
\hline & {$[6.25)$} & {$[8.86)$} & {$[9.79)$} & {$[12.95)$} & {$[5.70)$} & {$[7.58)$} & {$[7.19)$} & {$[6.25)$} & {$[9.85)$} & {$[9.06)$} \\
\hline \multirow[t]{3}{*}{ ALPHA } & -0.86 & 0.41 & 0.24 & -0.54 & -0.08 & -0.66 & -0.06 & -0.18 & 0.64 & -0.12 \\
\hline & $(-1.54)$ & $(0.89)$ & $(0.42)$ & $(-1.39)$ & $(-0.12)$ & $(-1.30)$ & $(-0.13)$ & $(-0.42)$ & $(1.40)$ & $(-0.29)$ \\
\hline & {$[-1.71)$} & {$[0.82)$} & {$[0.38)$} & {$[-1.63)$} & {$[-0.21)$} & {$[-1.36)$} & {$[-0.34)$} & {$[-0.64)$} & {$[1.36)$} & {$[-0.46)$} \\
\hline R-Squared & 0.5282 & 0.6761 & 0.6034 & 0.7705 & 0.5425 & 0.6539 & 0.6511 & 0.5769 & 0.7528 & 0.6115 \\
\hline
\end{tabular}




\begin{tabular}{|c|c|c|c|c|c|c|c|c|c|c|}
\hline \multicolumn{11}{|c|}{ Panel B: Same Period Bitcoin Return } \\
\hline $\mathrm{x} 100$ & food & beer & smoke & games & books & hshld & clths & hlth & chems & txtls \\
\hline \multirow[t]{3}{*}{ BITCOIN } & 2.02 & $3.89^{*}$ & 2.74 & -4.23 & -3.32 & 1.36 & -2.18 & 0.08 & 0.56 & -1.03 \\
\hline & $(1.18)$ & $(1.77)$ & $(0.76)$ & $(-1.50)$ & $(-1.61)$ & $(0.67)$ & $(-0.83)$ & $(0.05)$ & $(0.28)$ & $(-0.43)$ \\
\hline & {$[1.17)$} & {$[1.84)$} & {$[0.73)$} & {$[-2.12)$} & {$[-1.37)$} & {$[0.54)$} & {$[-0.87)$} & {$[0.04)$} & {$[0.25)$} & {$[-0.42)$} \\
\hline \multirow[t]{3}{*}{ MKTRF } & $0.49^{* * *}$ & $0.39^{* *}$ & 0.32 & $1.41^{* * *}$ & $1.39^{* * *}$ & $0.46^{* * *}$ & $0.51 * *$ & $1.11^{* * *}$ & $1.43^{* * *}$ & $0.98^{* * *}$ \\
\hline & (3.59) & $(2.22)$ & $(1.12)$ & $(6.28)$ & $(8.50)$ & $(2.83)$ & $(2.46)$ & $(7.94)$ & (8.93) & $(5.11)$ \\
\hline & {$[3.09)$} & {$[1.72)$} & {$[0.90)$} & {$[6.84)$} & {$[8.81)$} & {$[2.22)$} & {$[3.08)$} & {$[7.38)$} & {$[6.59)$} & {$[5.62)$} \\
\hline \multirow[t]{3}{*}{ ALPHA } & -0.48 & -0.20 & -0.22 & 1.23 & -0.62 & -0.43 & 0.31 & -0.79 & -0.20 & -1.04 \\
\hline & $(-1.00)$ & $(-0.32)$ & $(-0.22)$ & $(1.56)$ & $(-1.08)$ & $(-0.75)$ & $(0.42)$ & $(-1.60)$ & $(-0.36)$ & $(-1.54)$ \\
\hline & {$[-2.12)$} & {$[-0.48)$} & {$[-0.47)$} & {$[1.66)$} & {$[-1.38)$} & {$[-0.93)$} & {$[0.51)$} & {$[-1.68)$} & {$[-0.50)$} & {$[-1.80)$} \\
\hline R-Squared & 0.3564 & 0.2505 & 0.0699 & 0.5685 & 0.7069 & 0.2425 & 0.1705 & 0.6869 & 0.7371 & 0.4686 \\
\hline $\mathrm{x} 100$ & cnstr & steel & fabpr & elceq & autos & carry & mines & coal & oil & util \\
\hline \multirow[t]{3}{*}{ BITCOIN } & -1.97 & -1.88 & -2.98 & $-3.20^{*}$ & -1.31 & 1.20 & -1.89 & -8.50 & -3.48 & 2.75 \\
\hline & $(-0.86)$ & $(-0.45)$ & $(-1.38)$ & $(-1.80)$ & $(-0.61)$ & $(0.62)$ & $(-0.40)$ & $(-0.85)$ & $(-1.01)$ & $(1.17)$ \\
\hline & {$[-0.78)$} & {$[-0.41)$} & {$[-1.13)$} & {$[-1.57)$} & {$[-0.68)$} & {$[0.63)$} & {$[-0.52)$} & {$[-1.03)$} & {$[-0.96)$} & {$[1.26)$} \\
\hline \multirow[t]{3}{*}{ MKTRF } & $1.25^{* * *}$ & $1.66^{* * *}$ & $1.30^{* * *}$ & $1.32^{* * *}$ & $1.35^{* * *}$ & $1.14^{* * *}$ & $1.03^{* *}$ & 0.86 & $1.22^{* * *}$ & 0.18 \\
\hline & $(6.87)$ & $(5.00)$ & $(7.58)$ & $(9.31)$ & $(7.90)$ & $(7.44)$ & $(2.75)$ & (1.08) & $(4.48)$ & $(0.99)$ \\
\hline & {$[4.98)$} & {$[4.36)$} & {$[6.27)$} & {$[9.08)$} & {$[7.05)$} & {$[7.20)$} & {$[3.50)$} & {$[0.64)$} & {$[4.41)$} & {$[0.91)$} \\
\hline \multirow[t]{3}{*}{ ALPHA } & 0.13 & 0.28 & 0.87 & -0.26 & -0.60 & 0.59 & 0.94 & 1.72 & 0.12 & 0.06 \\
\hline & $(0.21)$ & $(0.24)$ & $(1.44)$ & $(-0.53)$ & $(-1.00)$ & $(1.10)$ & $(0.71)$ & $(0.62)$ & $(0.13)$ & $(0.09)$ \\
\hline & {$[0.17)$} & {$[0.24)$} & {$[1.47)$} & {$[-0.72)$} & {$[-1.12)$} & {$[1.01)$} & {$[0.75)$} & {$[0.69)$} & {$[0.09)$} & {$[0.04)$} \\
\hline R-Squared & 0.6126 & 0.4579 & 0.6570 & 0.7429 & 0.6790 & 0.6667 & 0.2015 & 0.0500 & 0.4006 & 0.0886 \\
\hline $\mathrm{x} 100$ & telcm & servs & buseq & paper & trans & whlsl & rtail & meals & fin & other \\
\hline \multirow[t]{3}{*}{ BITCOIN } & -0.83 & -0.11 & 2.16 & 1.02 & 0.05 & -0.80 & 0.31 & $3.58^{* *}$ & -1.65 & -0.09 \\
\hline & $(-0.40)$ & $(-0.06)$ & $(1.04)$ & $(0.70)$ & $(0.02)$ & $(-0.44)$ & $(0.19)$ & $(2.11)$ & $(-0.87)$ & $(-0.06)$ \\
\hline & {$[-0.39)$} & {$[-0.08)$} & {$[1.07)$} & {$[0.71)$} & {$[0.02)$} & {$[-0.45)$} & {$[0.13)$} & {$[2.20)$} & {$[-1.23)$} & {$[-0.09)$} \\
\hline \multirow[t]{3}{*}{ MKTRF } & $0.93^{* * *}$ & $1.04^{* * *}$ & $1.04^{* * *}$ & $1.09^{* * *}$ & $1.08^{* * *}$ & $1.10^{* * *}$ & $0.95^{* * *}$ & $0.65^{* * *}$ & $1.21^{* * *}$ & $0.82^{* * *}$ \\
\hline & $(5.67)$ & $(7.67)$ & $(6.34)$ & $(9.36)$ & $(5.83)$ & $(7.48)$ & $(7.15)$ & $(4.84)$ & $(8.12)$ & $(6.74)$ \\
\hline & {$[6.77)$} & {$[8.58)$} & {$[8.88)$} & {$[12.18)$} & {$[6.14)$} & {$[7.22)$} & {$[6.22)$} & {$[6.08)$} & {$[7.99)$} & {$[7.95)$} \\
\hline \multirow[t]{3}{*}{ ALPHA } & -0.58 & 0.56 & 0.21 & -0.44 & -0.04 & -0.52 & 0.06 & -0.10 & 0.29 & -0.15 \\
\hline & $(-1.01)$ & $(1.18)$ & $(0.37)$ & $(-1.08)$ & $(-0.06)$ & $(-1.01)$ & $(0.14)$ & $(-0.21)$ & $(0.56)$ & $(-0.35)$ \\
\hline & {$[-1.35)$} & {$[1.24)$} & {$[0.35)$} & {$[-1.66)$} & {$[-0.15)$} & {$[-1.24)$} & {$[0.06)$} & {$[-0.34)$} & {$[0.59)$} & {$[-0.52)$} \\
\hline R-Squared & 0.5211 & 0.6706 & 0.6038 & 0.7588 & 0.5420 & 0.6556 & 0.6424 & 0.5259 & 0.6890 & 0.6109 \\
\hline
\end{tabular}

Furthermore, we examine the exposures of different regions to Bitcoin risk. Table 36 documents our findings. We obtain the return series of the different regions from Kenneth French's website. U.S., Europe, Japan, and Canada have similar exposures to Bitcoin risk - all positive but not statistically significant. Note that the point estimate for Europe is somewhat higher and for AsiaExJapan is significantly lower than the rest. 
Table 36: Country Exposure to Bitcoin Returns

\begin{tabular}{lccccc}
\hline x100 & U.S. & Europe & Japan & AsiaExJapan & North America \\
\hline \multirow{2}{*}{ BITCOIN } & 0.72 & 0.95 & 0.77 & 0.33 & 0.68 \\
& $(1.45)$ & $(1.42)$ & $(1.40)$ & $(0.46)$ & $(1.35)$ \\
ALPHA & $0.90^{* *}$ & 0.43 & 0.55 & 0.36 & $0.82^{* *}$ \\
& $(2.49)$ & $(0.89)$ & $(1.37)$ & $(0.69)$ & $(2.24)$ \\
& & & & & \\
R-squared & 0.02 & 0.02 & 0.02 & 0.00 & 0.02 \\
\hline
\end{tabular}

\subsection{Potential Winners and Losers: Index of Cryptocurrency Exposures}

In this section, we estimate the 354 U.S. SIC 3-digit industries' on cryptocurrency returns and 137 of China's CIC industries exposures on Bitcoin returns, controlling for the excess market returns. Specifically, we regress each industry's stock returns on the contemporaneous Bitcoin returns and the excess stock market returns. Each industry's stock return is calculated as value-weighted returns from individual publicly listed companies in the industry. The complete results are reported in the Appendix for conciseness. We then standardize the exposure estimates to have mean zero and standard deviation of one to create an index of the exposures of the industries to the cryptocurrencies. Figure 5 reports the histogram of the values of the index for each cryptocurrency for the 354 US industries and Figure 6 reports the same for the 137 Chinese industries.

Figure 5: Industry Distribution of Cryptocurrency Exposure Index
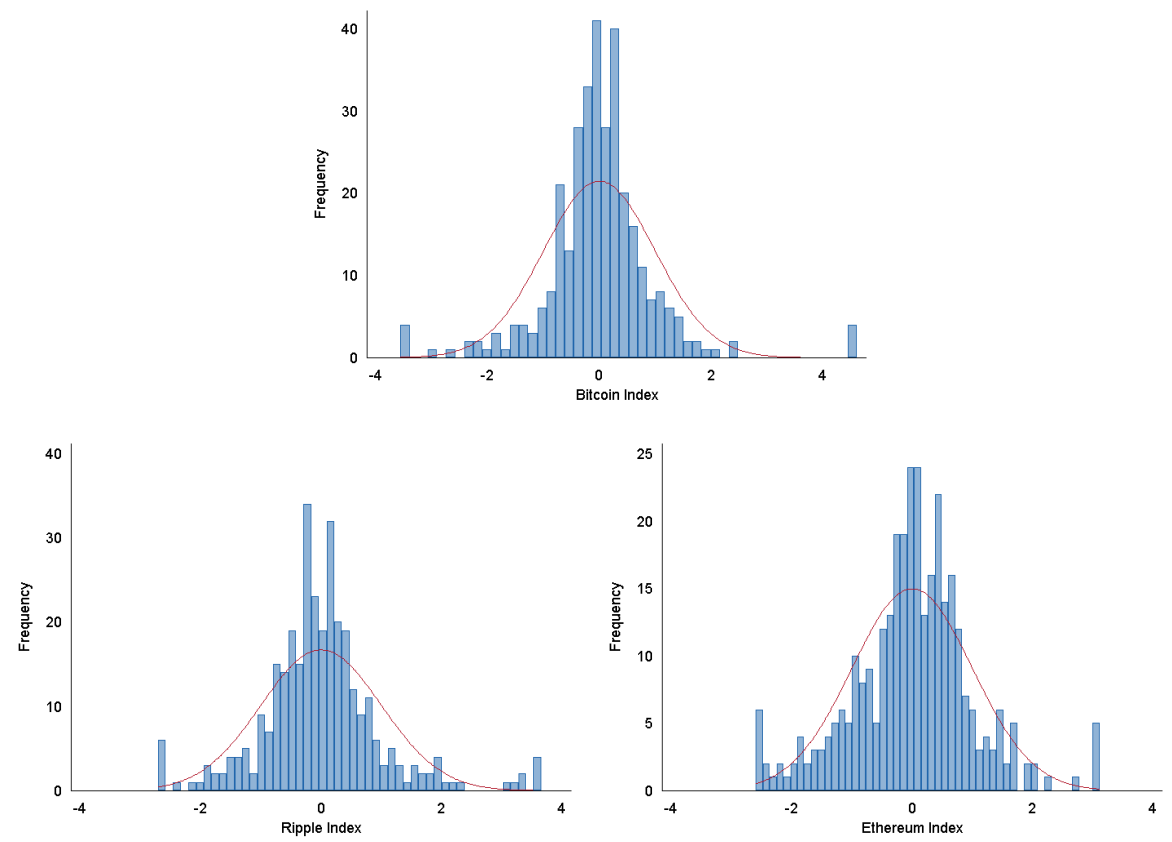
Figure 6: Industry Distribution of Cryptocurrency Exposure Index - China

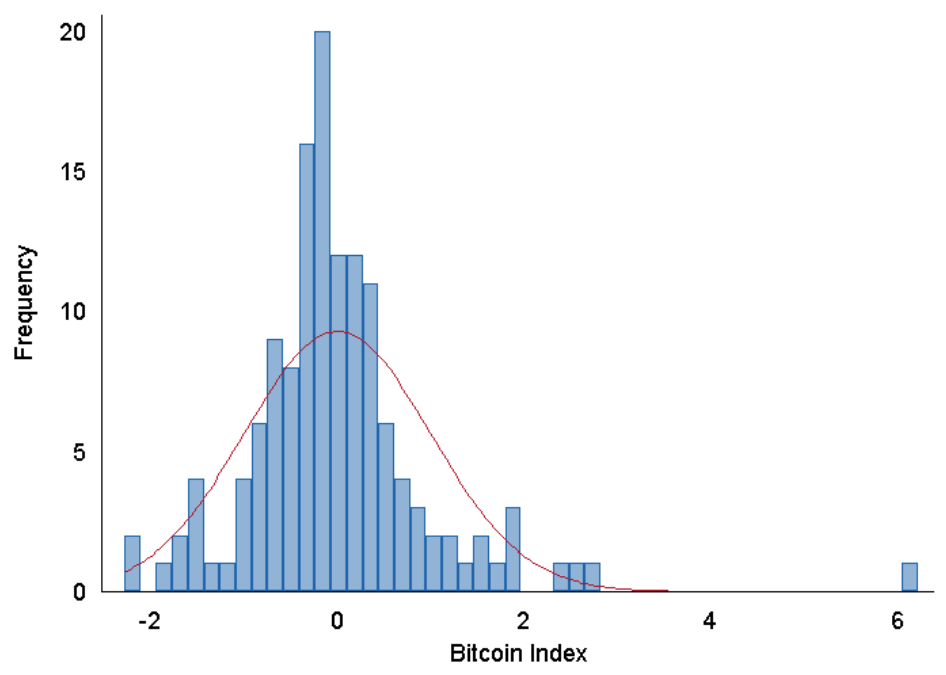

\section{Conclusion}

We conclude that cryptocurrency returns have low exposures to traditional asset classes - stocks, currencies, and commodities. Our findings cast doubt on popular explanations that the behavior of cryptocurrencies is driven by its functions as a stake in the future of blockhain technology similar to stocks, as a unit of account similar to currencies, or as a store of value similar to precious metal commodities. At the same time, the returns of cryptocurrency can be predicted by two factors specific to its markets - momentum and investors attention. Our findings call into question popular explanations that supply factors such as mining costs, price-to-"dividend" ratio, or realized volatitility are useful for predicting the behavior of cryptocurrency returns. Finally, we document that the blockchain technology embodied in cryptocurrencies has a potential to affect a number of important industries. 


\section{References}

Abadi, Joseph and Markus Brunnermeier. 2018. "Blockchain economics." Tech. rep., mimeo Princeton University.

Asness, Clifford S, Tobias J Moskowitz, and Lasse Heje Pedersen. 2013. "Value and momentum everywhere." The Journal of Finance 68 (3):929-985.

Asvanunt, Attakrit and Scott Richardson. 2016. "The credit risk premium." Working Paper .

Barro, Robert J. 2006. "Rare disasters and asset markets in the twentieth century." The Quarterly Journal of Economics 121 (3):823-866.

Biais, Bruno, Christophe Bisiere, Matthieu Bouvard, and Catherine Casamatta. 2018. "The blockchain folk theorem." Working Paper .

Bianchi, Daniele. 2017. "Cryptocurrencies as an asset class: An empirical assessment." Working Paper .

Black, Fischer and Robert Litterman. 1990. "Asset allocation: Combining investor views with market equilibrium." Tech. rep., Discussion paper, Goldman, Sachs \& Co.

—. 1992. "Global portfolio optimization." Financial Analysts Journal 48 (5):28-43.

Borri, Nicola. 2018. "Conditional tail-risk in cryptocurrency markets." Working Paper .

Borri, Nicola and Kirill Shakhnov. 2018. "Cryptomarket discounts." Working Paper .

Campbell, John Y and Robert J Shiller. 1988. "The dividend-price ratio and expectations of future dividends and discount factors." Review of Financial Studies 1 (3):195-228.

. 1991. "Yield spreads and interest rate movements: A bird's eye view." Review of Economic Studies 58 (3):495-514.

Carhart, Mark M. 1997. "On persistence in mutual fund performance." The Journal of Finance 52 (1):57-82.

Chen, Andrew and Mihail Velikov. 2017. "Accounting for the anomaly zoo: A trading cost perspective." Working Paper.

Chen, Andrew Y and Tom Zimmermann. 2018. "Publication bias and the cross-section of stock returns." Working Paper.

Chiu, Jonathan and Thorsten V Koeppl. 2017. "The economics of cryptocurrencies-bitcoin and beyond." Working Paper .

Cong, Lin William and Zhiguo He. 2018. "Blockchain disruption and smart contracts." Tech. rep., National Bureau of Economic Research.

Cong, Lin William, Zhiguo He, and Jiasun Li. 2018. "Decentralized mining in centralized pools." Working Paper .

Cong, Lin William, Ye Li, and Neng Wang. 2018. "Tokenomics: Dynamic adoption and valuation." Working Paper . 
Da, Zhi, Joseph Engelberg, and Pengjie Gao. 2011. "In search of attention." The Journal of Finance 66 (5):1461-1499.

Daniel, Kent and Tobias J Moskowitz. 2016. "Momentum crashes." Journal of Financial Economics $122(2): 221-247$.

Fama, Eugene F and Kenneth R French. 1993. "Common risk factors in the returns on stocks and bonds." Journal of Financial Economics 33 (1):3-56.

—. 1996. "Multifactor explanations of asset pricing anomalies." The Journal of Finance 51 (1):55-84.

—. 1997. "Industry costs of equity." Journal of Financial Economics 43 (2):153-193.

—. 2016a. "Choosing factors." Working Paper .

—. 2016b. "Dissecting anomalies with a five-factor model." Review of Financial Studies 29 (1):69-103.

Feng, Guanhao, Stefano Giglio, and Dacheng Xiu. 2017. "Taming the factor zoo." Working Paper .

Foley, Sean, Jonathan Karlsen, and Tālis J Putninšs. 2018. "Sex, drugs, and bitcoin: How much illegal activity is financed through cryptocurrencies?" Working Paper .

Gilbert, Scott and Hio Loi. 2018. "Digital currency risk." International Journal of Economics and Finance $10(2): 108$.

He, Guangliang and Robert Litterman. 1999. "The intuition behind Black-Litterman model portfolios." Working Paper.

Hou, Kewei, Chen Xue, and Lu Zhang. 2015. "Digesting anomalies: An investment approach." Review of Financial Studies 28 (3):650-705.

Hu, Albert, Christine A Parlour, and Uday Rajan. 2018. "Cryptocurrencies: Stylized facts on a new investible instrument." Working Paper .

Huberman, Gur, Jacob D Leshno, and Ciamac C Moallemi. 2017. "Monopoly without a monopolist: An economic analysis of the bitcoin payment system." Working Paper .

Jegadeesh, Narasimhan and Sheridan Titman. 1993. "Returns to buying winners and selling losers: Implications for stock market efficiency." The Journal of Finance 48 (1):65-91.

Lustig, Hanno, Nikolai Roussanov, and Adrien Verdelhan. 2011. "Common risk factors in currency markets." Review of Financial Studies 24 (11):3731-3777.

Mai, Feng, Qing Bai, Zhe Shan, Xin Shane Wang, and Roger Chiang. 2016. "The impacts of social media on Bitcoin performance." Working Paper .

Makarov, Igor and Antoinette Schoar. 2018. "Trading and arbitrage in cryptocurrency markets." Working Paper.

Moskowitz, Tobias J and Mark Grinblatt. 1999. "Do industries explain momentum?" The Journal of Finance 54 (4):1249-1290. 
Moskowitz, Tobias J, Yao Hua Ooi, and Lasse Heje Pedersen. 2012. "Time series momentum." Journal of Financial Economics 104 (2):228-250.

Routledge, Bryan and Ariel Zetlin-Jones. 2018. "Currency stability using blockchain technology." Working Paper.

Saleh, Fahad. 2018. "Blockchain without waste: Proof-of-stake." Working Paper .

Schilling, Linda and Harald Uhlig. 2018. "Some simple bitcoin economics." Tech. rep., National Bureau of Economic Research.

Sockin, Michael and Wei Xiong. 2018. "A model of cryptocurrencies." Tech. rep., Working paper.

Stoffels, Jaron. 2017. "Asset pricing of cryptocurrencies and momentum based patterns." Working Paper .

Urquhart, Andrew. 2018. "What causes the attention of bitcoin?" Working Paper .

Wang, Sha and Jean-Philippe Vergne. 2017. "Buzz factor or innovation potential: What explains cryptocurrencies' returns?" PloS One 12 (1):e0169556.

Weber, Warren E. 2016. "A Bitcoin standard: Lessons from the gold standard.” Tech. rep., Bank of Canada Staff Working Paper.

Yermack, David. 2015. "Is Bitcoin a real currency? An economic appraisal." In Handbook of Digital Currency. Elsevier, 31-43. 


\section{Appendix A: Graphs \& Tables}

Figure A.1: Cryptocurrency Returns
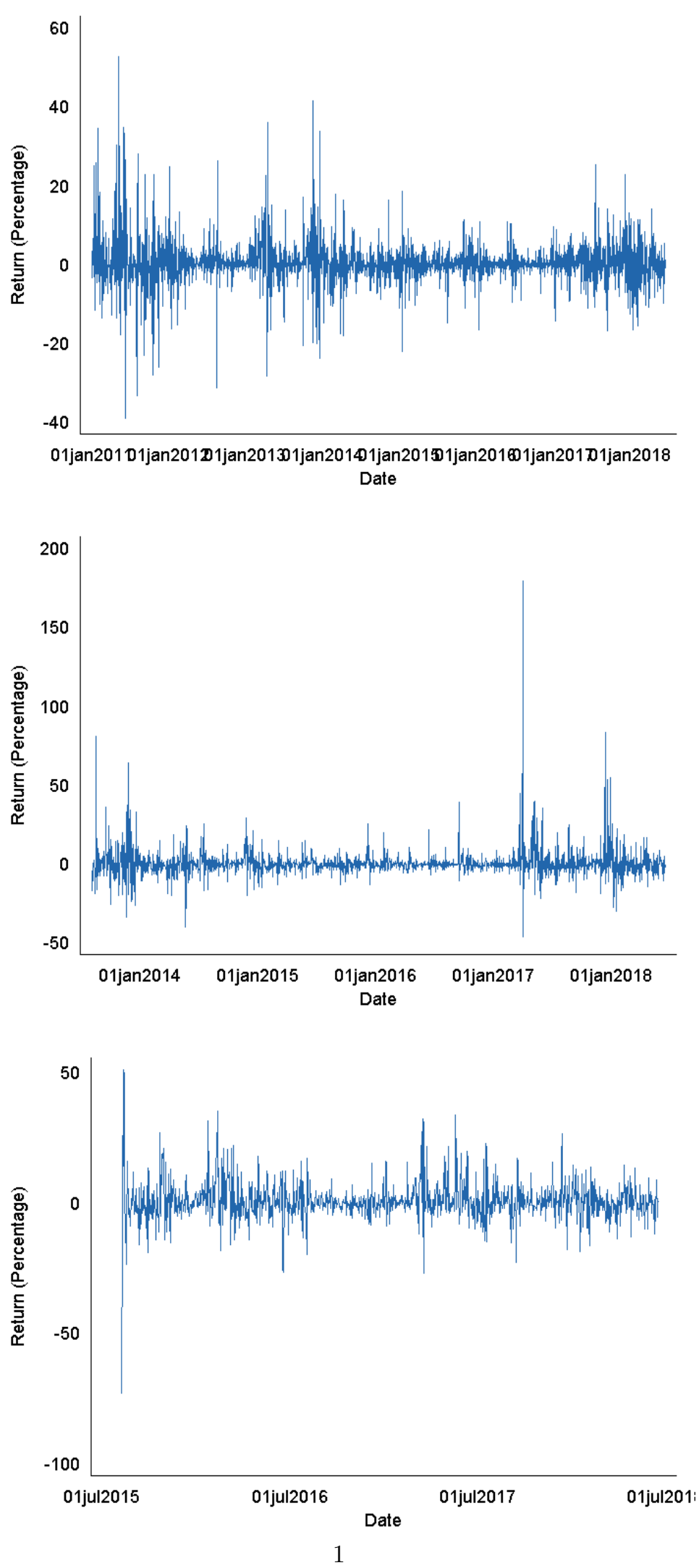
Figure A.2: Bitcoin Wallet Users

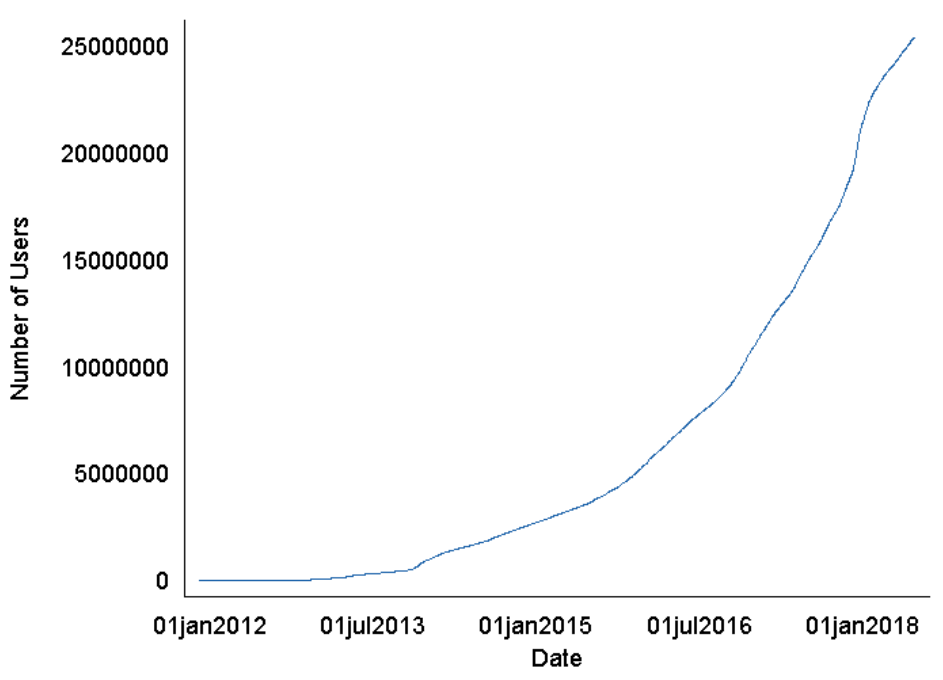


Table A.1: Additional Summary Statistics

\begin{tabular}{|c|c|c|c|c|c|}
\hline \multicolumn{6}{|c|}{ Top 10 Extreme Gains and Losses } \\
\hline Disasters & Month & Gains & Miracles & Month & Losses \\
\hline 1 & 2013/11 & $173.59 \%$ & 1 & $2011 / 08$ & $-48.74 \%$ \\
\hline 2 & $2011 / 04$ & $150.12 \%$ & 2 & 2011/09 & $-46.71 \%$ \\
\hline 3 & $2013 / 03$ & $102.50 \%$ & 3 & $2011 / 10$ & $-45.84 \%$ \\
\hline 4 & $2011 / 05$ & $91.51 \%$ & 4 & $2014 / 02$ & $-44.44 \%$ \\
\hline 5 & $2011 / 06$ & $61.09 \%$ & 5 & 2018/03 & $-39.78 \%$ \\
\hline 6 & 2011/01 & $55.00 \%$ & 6 & $2013 / 12$ & $-39.53 \%$ \\
\hline 7 & $2017 / 05$ & $54.74 \%$ & 7 & $2015 / 01$ & $-38.79 \%$ \\
\hline 8 & $2017 / 08$ & $50.56 \%$ & 8 & $2018 / 01$ & $-30.99 \%$ \\
\hline 9 & 2011/02 & $50.31 \%$ & 9 & $2013 / 06$ & $-27.85 \%$ \\
\hline \multirow[t]{7}{*}{10} & 2013/02 & $49.19 \%$ & 10 & 2014/09 & $-21.32 \%$ \\
\hline & \multicolumn{5}{|c|}{ Correlation } \\
\hline & \multicolumn{5}{|c|}{ Bitcoin } \\
\hline & \multicolumn{2}{|c|}{ Bitcoin } & a $\quad 1.00$ & & \\
\hline & \multicolumn{2}{|c|}{ Stock } & 0.16 & & \\
\hline & \multicolumn{2}{|c|}{ Bond } & -0.04 & & \\
\hline & \multicolumn{2}{|r|}{ House } & 0.11 & & \\
\hline \multicolumn{6}{|c|}{ Bitcoin Log Return } \\
\hline & Mean & SD & T-Statistics & Skewness & Kurtosis \\
\hline Daily & $0.37 \%$ & $5.51 \%$ & 3.47 & -0.31 & 14.84 \\
\hline Weekly & $2.56 \%$ & $14.99 \%$ & 3.37 & 0.53 & 6.64 \\
\hline Monthly & $11.08 \%$ & $36.74 \%$ & 2.86 & 1.67 & 8.04 \\
\hline \multicolumn{6}{|c|}{ Ripple Log Return } \\
\hline & Mean & $\mathrm{SD}$ & T-Statistics & Skewness & Kurtosis \\
\hline Daily & $0.25 \%$ & $7.94 \%$ & 1.34 & 2.01 & 29.97 \\
\hline Weekly & $1.77 \%$ & $25.22 \%$ & 1.12 & 2.88 & 19.63 \\
\hline Monthly & $7.62 \%$ & $57.50 \%$ & 1.02 & 1.81 & 6.54 \\
\hline \multicolumn{6}{|c|}{ Ethereum Log Return } \\
\hline & Mean & SD & T-Statistics & Skewness & Kurtosis \\
\hline Daily & $0.50 \%$ & $8.19 \%$ & 1.96 & -3.52 & 66.46 \\
\hline Weekly & $4.41 \%$ & $20.64 \%$ & 2.61 & 0.82 & 4.44 \\
\hline Monthly & $14.85 \%$ & $48.18 \%$ & 1.82 & 0.24 & 2.57 \\
\hline
\end{tabular}


Table A.2: Characteristics of Predictors

\begin{tabular}{|c|c|c|c|c|c|c|}
\hline \multicolumn{7}{|c|}{ Summary Statistics of Predictors } \\
\hline (Weekly) & Mean & SD & $\mathrm{AR}(1)$ & $\mathrm{AR}(2)$ & $\mathrm{AR}(4)$ & $\operatorname{AR}(8)$ \\
\hline Google (Bitcoin) & 0.00 & 1.00 & 0.66 & 0.31 & -0.18 & -0.04 \\
\hline Google (Ripple) & 0.00 & 1.00 & 0.76 & 0.42 & -0.24 & -0.18 \\
\hline Google (Ethereum) & 0.00 & 1.00 & 0.64 & 0.32 & 0.13 & -0.27 \\
\hline Twitter & 0.00 & 1.00 & 0.34 & 0.04 & -0.27 & 0.29 \\
\hline Hack & 0.00 & 1.00 & 0.44 & 0.44 & 0.37 & 0.38 \\
\hline Price-to-"Dividend" & 0.00 & 1.00 & 0.99 & 0.98 & 0.97 & 0.95 \\
\hline \multicolumn{7}{|c|}{ Stationarity Tests of Predictors } \\
\hline & \multicolumn{4}{|c|}{ ADF t-statistics } & \multicolumn{2}{|c|}{ Critical Values } \\
\hline (Weekly) & 1 & 2 & 3 & 4 & $1 \%$ & $5 \%$ \\
\hline Google (Bitcoin) & -10.10 & -10.67 & -10.13 & -7.46 & -3.99 & -3.43 \\
\hline Google (Ripple) & -8.17 & -9.07 & -9.68 & -6.66 & -3.99 & -3.43 \\
\hline Google (Ethereum) & -5.91 & -4.23 & -4.82 & -4.13 & -4.03 & -3.44 \\
\hline Twitter & -12.13 & -11.37 & -12.37 & -10.34 & -3.99 & -3.43 \\
\hline Hack & -7.82 & -6.28 & -5.22 & -4.43 & -3.99 & -3.43 \\
\hline Price-to-"Dividend" & -7.30 & -4.46 & -4.57 & -3.81 & -3.99 & -3.43 \\
\hline
\end{tabular}


Table A.3: Bitcoin Return Exposures to the Factor Zoo

\begin{tabular}{|c|c|c|c|c|c|c|c|c|c|c|c|c|c|c|c|}
\hline (Percentage) & (1) & (2) & (3) & $(4)$ & (5) & (6) & (7) & $(8)$ & (9) & $(10)$ & (11) & $(12)$ & (13) & (14) & $(15)$ \\
\hline VARIABLES & Return & Return & Return & Return & Return & Return & Return & Return & Return & Return & Return & Return & Return & Return & Return \\
\hline \multirow[t]{2}{*}{ mktrf } & 4.12 & 4.26 & 3.70 & 3.53 & 4.14 & 3.43 & 3.54 & 3.68 & 3.47 & 3.49 & 3.50 & 3.71 & 3.69 & 3.20 & 3.52 \\
\hline & $(1.56)$ & $(1.57)$ & $(1.39)$ & $(1.33)$ & $(1.34)$ & $(1.28)$ & $(1.33)$ & $(1.39)$ & $(1.31)$ & $(1.32)$ & $(1.32)$ & $(1.40)$ & $(0.93)$ & $(1.16)$ & $(1.33)$ \\
\hline \multirow[t]{2}{*}{ abnormalaccruals } & 9.65 & & & & & & & & & & & & & & \\
\hline & $(1.33)$ & & & & & & & & & & & & & & \\
\hline \multirow[t]{2}{*}{ accruals } & & 9.95 & & & & & & & & & & & & & \\
\hline & & $(1.06)$ & & & & & & & & & & & & & \\
\hline \multirow[t]{2}{*}{ accrualsbm } & & & 1.30 & & & & & & & & & & & & \\
\hline & & & $(0.46)$ & & & & & & & & & & & & \\
\hline \multirow[t]{2}{*}{ adexp } & & & & 0.11 & & & & & & & & & & & \\
\hline & & & & $(0.02)$ & & & & & & & & & & & \\
\hline \multirow[t]{2}{*}{ announcementreturn } & & & & & -1.18 & & & & & & & & & & \\
\hline & & & & & $(-0.30)$ & & & & & & & & & & \\
\hline \multirow[t]{2}{*}{ assetgrowth } & & & & & & 1.09 & & & & & & & & & \\
\hline & & & & & & $(0.24)$ & & & & & & & & & \\
\hline \multirow[t]{2}{*}{ assetturnover } & & & & & & & 0.07 & & & & & & & & \\
\hline & & & & & & & $(0.02)$ & & & & & & & & \\
\hline \multirow[t]{2}{*}{$\mathrm{bm}$} & & & & & & & & -1.67 & & & & & & & \\
\hline & & & & & & & & $(-0.61)$ & & & & & & & \\
\hline \multirow[t]{2}{*}{ bpebm } & & & & & & & & & 1.76 & & & & & & \\
\hline & & & & & & & & & $(0.31)$ & & & & & & \\
\hline \multirow[t]{2}{*}{ beta } & & & & & & & & & & 1.05 & & & & & \\
\hline & & & & & & & & & & $(0.51)$ & & & & & \\
\hline \multirow[t]{2}{*}{ betasquared } & & & & & & & & & & & 1.04 & & & & \\
\hline & & & & & & & & & & & $(0.51)$ & & & & \\
\hline \multirow[t]{2}{*}{ betatailrisk } & & & & & & & & & & & & 2.04 & & & \\
\hline & & & & & & & & & & & & $(0.83)$ & & & \\
\hline \multirow[t]{2}{*}{ bidaskspread } & & & & & & & & & & & & & 2.04 & & \\
\hline & & & & & & & & & & & & & $(0.65)$ & & \\
\hline \multirow[t]{2}{*}{ cboperprof } & & & & & & & & & & & & & & -1.49 & \\
\hline & & & & & & & & & & & & & & $(-0.45)$ & \\
\hline \multirow[t]{2}{*}{ cf } & & & & & & & & & & & & & & & 0.32 \\
\hline & & & & & & & & & & & & & & & $(0.09)$ \\
\hline
\end{tabular}




\begin{tabular}{|c|c|c|c|c|c|c|c|c|c|c|c|c|c|c|c|}
\hline $\begin{array}{l}\text { (Percentage) } \\
\text { VARIABLES }\end{array}$ & $\begin{array}{c}(16) \\
\text { Return }\end{array}$ & $\begin{array}{c}(17) \\
\text { Return } \\
\end{array}$ & $\begin{array}{l}(18) \\
\text { Return }\end{array}$ & $\begin{array}{l}(19) \\
\text { Return }\end{array}$ & $\begin{array}{c}(20) \\
\text { Return }\end{array}$ & $\begin{array}{l}(21) \\
\text { Return }\end{array}$ & $\begin{array}{l}(22) \\
\text { Return }\end{array}$ & $\begin{array}{c}(23) \\
\text { Return }\end{array}$ & $\begin{array}{l}(24) \\
\text { Return }\end{array}$ & $\begin{array}{l}(25) \\
\text { Return }\end{array}$ & $\begin{array}{l}(26) \\
\text { Return }\end{array}$ & $\begin{array}{l}(27) \\
\text { Return }\end{array}$ & $\begin{array}{l}(28) \\
\text { Return }\end{array}$ & $\begin{array}{l}(29) \\
\text { Return }\end{array}$ & $\begin{array}{l}(30) \\
\text { Return }\end{array}$ \\
\hline \multirow{2}{*}{ mktrf } & 3.43 & 3.55 & 3.50 & 3.79 & 3.53 & 3.93 & 4.00 & 3.54 & 3.60 & 3.49 & 3.48 & 3.55 & 3.59 & 3.49 & 3.81 \\
\hline & $(1.30)$ & $(1.32)$ & $(1.31)$ & (1.44) & (1.34) & (1.48) & $(1.52)$ & $(1.34)$ & $(1.35)$ & $(1.31)$ & $(1.31)$ & $(1.34)$ & $(1.35)$ & $(1.32)$ & $(1.44)$ \\
\hline \multirow[t]{2}{*}{ cash } & 1.72 & & & & & & & & & & & & & & \\
\hline & $(0.58)$ & & & & & & & & & & & & & & \\
\hline \multirow[t]{2}{*}{ chassetturnover } & & 0.23 & & & & & & & & & & & & & \\
\hline & & $(0.03)$ & & & & & & & & & & & & & \\
\hline \multirow[t]{2}{*}{ cheq } & & & 0.47 & & & & & & & & & & & & \\
\hline & & & $(0.10)$ & & & & & & & & & & & & \\
\hline \multirow[t]{2}{*}{ chforecastaccrual } & & & & -7.27 & & & & & & & & & & & \\
\hline & & & & $(-1.08)$ & & & & & & & & & & & \\
\hline \multirow[t]{2}{*}{ chinv } & & & & & 1.74 & & & & & & & & & & \\
\hline & & & & & $(0.23)$ & & & & & & & & & & \\
\hline \multirow[t]{2}{*}{ chinvia } & & & & & & -6.77 & & & & & & & & & \\
\hline & & & & & & $(-1.09)$ & & & & & & & & & \\
\hline \multirow[t]{2}{*}{ chnanalyst } & & & & & & & -14.72 & & & & & & & & \\
\hline & & & & & & & $(-1.44)$ & & & & & & & & \\
\hline \multirow[t]{2}{*}{ chncoa } & & & & & & & & 2.08 & & & & & & & \\
\hline & & & & & & & & $(0.23)$ & & & & & & & \\
\hline \multirow[t]{2}{*}{ chnwc } & & & & & & & & & 1.76 & & & & & & \\
\hline & & & & & & & & & $(0.18)$ & & & & & & \\
\hline \multirow[t]{2}{*}{ chpm } & & & & & & & & & & -1.66 & & & & & \\
\hline & & & & & & & & & & $(-0.21)$ & & & & & \\
\hline \multirow[t]{2}{*}{ chtax } & & & & & & & & & & & -2.27 & & & & \\
\hline & & & & & & & & & & & $(-0.40)$ & & & & \\
\hline \multirow[t]{2}{*}{ changeinrecommendation } & & & & & & & & & & & & -2.70 & & & \\
\hline & & & & & & & & & & & & $(-0.46)$ & & & \\
\hline \multirow[t]{2}{*}{ compositedebtissuance } & & & & & & & & & & & & & -1.20 & & \\
\hline & & & & & & & & & & & & & $(-0.20)$ & & \\
\hline \multirow[t]{2}{*}{ consrecomm } & & & & & & & & & & & & & & -2.90 & \\
\hline & & & & & & & & & & & & & & $(-0.86)$ & \\
\hline \multirow[t]{2}{*}{ convdebt } & & & & & & & & & & & & & & & -4.84 \\
\hline & & & & & & & & & & & & & & & $(-0.88)$ \\
\hline
\end{tabular}




\begin{tabular}{|c|c|c|c|c|c|c|c|c|c|c|c|c|c|c|c|}
\hline (Percentage) & (31) & (32) & (33) & (34) & (35) & (36) & (37) & (38) & (39) & $(40)$ & (41) & $(42)$ & (43) & (44) & (45) \\
\hline VARIABLES & Return & Return & Return & Return & Return & Return & Return & Return & Return & Return & Return & Return & Return & Return & Return \\
\hline \multirow[t]{2}{*}{ mktrf } & 3.57 & 3.52 & 4.21 & 3.54 & 3.88 & 3.66 & 3.37 & 3.65 & 3.58 & 3.09 & 3.56 & 2.61 & 3.26 & 4.05 & 3.70 \\
\hline & (1.30) & (1.33) & (1.34) & (1.34) & $(1.44)$ & (1.38) & $(1.25)$ & $(1.40)$ & (1.36) & $(1.17)$ & $(1.35)$ & $(0.96)$ & $(1.23)$ & (1.46) & (1.39) \\
\hline \multirow[t]{2}{*}{ credratdg } & -0.51 & & & & & & & & & & & & & & \\
\hline & $(-0.30)$ & & & & & & & & & & & & & & \\
\hline \multirow[t]{2}{*}{ debtissuance } & & -0.87 & & & & & & & & & & & & & \\
\hline & & $(-0.11)$ & & & & & & & & & & & & & \\
\hline \multirow[t]{2}{*}{ delbreadth } & & & -2.20 & & & & & & & & & & & & \\
\hline & & & $(-0.45)$ & & & & & & & & & & & & \\
\hline \multirow[t]{2}{*}{ delcoa } & & & & -0.88 & & & & & & & & & & & \\
\hline & & & & $(-0.13)$ & & & & & & & & & & & \\
\hline \multirow[t]{2}{*}{ delcol } & & & & & -3.65 & & & & & & & & & & \\
\hline & & & & & $(-0.62)$ & & & & & & & & & & \\
\hline \multirow[t]{2}{*}{ deldrc } & & & & & & 2.39 & & & & & & & & & \\
\hline & & & & & & $(0.45)$ & & & & & & & & & \\
\hline \multirow[t]{2}{*}{ delequ } & & & & & & & 1.80 & & & & & & & & \\
\hline & & & & & & & $(0.32)$ & & & & & & & & \\
\hline \multirow[t]{2}{*}{ delfinl } & & & & & & & & -11.86 & & & & & & & \\
\hline & & & & & & & & $(-1.30)$ & & & & & & & \\
\hline \multirow[t]{2}{*}{ dellti } & & & & & & & & & 8.57 & & & & & & \\
\hline & & & & & & & & & $(0.77)$ & & & & & & \\
\hline \multirow[t]{2}{*}{ divind } & & & & & & & & & & -6.06 & & & & & \\
\hline & & & & & & & & & & $(-1.11)$ & & & & & \\
\hline \multirow[t]{2}{*}{ divinit } & & & & & & & & & & & 2.53 & & & & \\
\hline & & & & & & & & & & & $(0.50)$ & & & & \\
\hline \multirow[t]{2}{*}{ divomit } & & & & & & & & & & & & -6.76 & & & \\
\hline & & & & & & & & & & & & $(-1.28)$ & & & \\
\hline \multirow[t]{2}{*}{ divyield } & & & & & & & & & & & & & -3.32 & & \\
\hline & & & & & & & & & & & & & $(-0.96)$ & & \\
\hline \multirow[t]{2}{*}{ dolvol } & & & & & & & & & & & & & & -1.99 & \\
\hline & & & & & & & & & & & & & & $(-0.61)$ & \\
\hline \multirow[t]{2}{*}{ downforecast } & & & & & & & & & & & & & & & -3.85 \\
\hline & & & & & & & & & & & & & & & $(-0.58)$ \\
\hline
\end{tabular}




\begin{tabular}{|c|c|c|c|c|c|c|c|c|c|c|c|c|c|c|c|}
\hline $\begin{array}{l}\text { (Percentage) } \\
\text { VARIABLES }\end{array}$ & $\begin{array}{c}\begin{array}{c}(46) \\
\text { Return }\end{array} \\
\end{array}$ & $\begin{array}{l}(47) \\
\text { Return }\end{array}$ & $\begin{array}{c}(48) \\
\text { Return } \\
\end{array}$ & $\begin{array}{c}(49) \\
\text { Return } \\
\end{array}$ & $\begin{array}{l}(50) \\
\text { Return }\end{array}$ & $\begin{array}{c}\begin{array}{c}(51) \\
\text { Return }\end{array} \\
\end{array}$ & $\begin{array}{c}\quad(52) \\
\text { Return } \\
\end{array}$ & $\begin{array}{c}(53) \\
\text { Return }\end{array}$ & $\begin{array}{c}(54) \\
\text { Return }\end{array}$ & $\begin{array}{l}\text { (55) } \\
\text { Return }\end{array}$ & $\begin{array}{l}(56) \\
\text { Return }\end{array}$ & $\begin{array}{c}(57) \\
\text { Return }\end{array}$ & $\begin{array}{c}(58) \\
\text { Return }\end{array}$ & $\begin{array}{c}(59) \\
\text { Return }\end{array}$ & $\begin{array}{l}(60) \\
\text { Return }\end{array}$ \\
\hline mktrf & $\begin{array}{c}3.53 \\
(1.34)\end{array}$ & $\begin{array}{c}3.56 \\
(1.35)\end{array}$ & $\begin{array}{c}3.43 \\
(1.29)\end{array}$ & $\begin{array}{c}3.43 \\
(1.29)\end{array}$ & $\begin{array}{c}3.42 \\
(1.29)\end{array}$ & $\begin{array}{c}3.50 \\
(1.33)\end{array}$ & $\begin{array}{c}3.45 \\
(1.30)\end{array}$ & $\begin{array}{c}3.36 \\
(1.25)\end{array}$ & $\begin{array}{l}4.01 \\
(1.49)\end{array}$ & $\begin{array}{l}4.14 \\
(1.34)\end{array}$ & $\begin{array}{c}3.57 \\
(1.31)\end{array}$ & $\begin{array}{c}3.20 \\
(1.19)\end{array}$ & $\begin{array}{c}3.57 \\
(1.35)\end{array}$ & $\begin{array}{l}4.38 \\
(1.64)\end{array}$ & $\begin{array}{c}3.74 \\
(1.44)\end{array}$ \\
\hline ebm & $\begin{array}{c}-4.49 \\
(-0.66)\end{array}$ & & & & & & & & & & & & & & \\
\hline ep & & $\begin{array}{l}-1.47 \\
(-0.30)\end{array}$ & & & & & & & & & & & & & \\
\hline earnsupbig & & & $\begin{array}{l}1.88 \\
(0.43)\end{array}$ & & & & & & & & & & & & \\
\hline earningsconsistency & & & & $\begin{array}{l}-2.42 \\
(-0.48)\end{array}$ & & & & & & & & & & & \\
\hline earningssurprise & & & & & $\begin{array}{c}2.36 \\
(0.39)\end{array}$ & & & & & & & & & & \\
\hline entmult & & & & & & $\begin{array}{c}-3.53 \\
(-0.80)\end{array}$ & & & & & & & & & \\
\hline exchswitch & & & & & & & $\begin{array}{c}1.26 \\
(0.56)\end{array}$ & & & & & & & & \\
\hline exclexp & & & & & & & & $\begin{array}{c}2.15 \\
(0.36)\end{array}$ & & & & & & & \\
\hline fr & & & & & & & & & $\begin{array}{c}-5.20 \\
(-0.84)\end{array}$ & & & & & & \\
\hline failureprobability & & & & & & & & & & $\begin{array}{c}0.50 \\
(0.10)\end{array}$ & & & & & \\
\hline firmagemom & & & & & & & & & & & $\begin{array}{c}-0.12 \\
(-0.06)\end{array}$ & & & & \\
\hline forecastdispersion & & & & & & & & & & & & $\begin{array}{c}-1.98 \\
(-0.66)\end{array}$ & & & \\
\hline frontier & & & & & & & & & & & & & $\begin{array}{c}-0.52 \\
(-0.18)\end{array}$ & & \\
\hline gp & & & & & & & & & & & & & & $\begin{array}{l}6.24 \\
(1.45)\end{array}$ & \\
\hline gradexp & & & & & & & & & & & & & & & $\begin{array}{l}-15.19^{*} \\
(-1.74)\end{array}$ \\
\hline
\end{tabular}




\begin{tabular}{|c|c|c|c|c|c|c|c|c|c|c|c|c|c|c|c|}
\hline $\begin{array}{l}\text { (Percentage) } \\
\text { VARIABLES }\end{array}$ & $\begin{array}{c}(61) \\
\text { Return }\end{array}$ & $\begin{array}{c}(62) \\
\text { Return }\end{array}$ & $\begin{array}{l}(63) \\
\text { Return }\end{array}$ & $\begin{array}{l}(64) \\
\text { Return }\end{array}$ & $\begin{array}{c}(65) \\
\text { Return }\end{array}$ & $\begin{array}{c}(66) \\
\text { Return }\end{array}$ & $\begin{array}{l}(67) \\
\text { Return }\end{array}$ & $\begin{array}{c}(68) \\
\text { Return }\end{array}$ & $\begin{array}{c}(69) \\
\text { Return }\end{array}$ & $\begin{array}{c}(70) \\
\text { Return }\end{array}$ & $\begin{array}{c}(71) \\
\text { Return }\end{array}$ & $\begin{array}{c}(72) \\
\text { Return }\end{array}$ & $\begin{array}{c}(73) \\
\text { Return }\end{array}$ & $\begin{array}{l}(74) \\
\text { Return }\end{array}$ & $\begin{array}{l}(75) \\
\text { Return }\end{array}$ \\
\hline mktrf & $\begin{array}{c}3.62 \\
(1.37)\end{array}$ & $\begin{array}{c}3.48 \\
(1.31)\end{array}$ & $\begin{array}{c}3.86 \\
(1.44)\end{array}$ & $\begin{array}{c}3.78 \\
(1.42)\end{array}$ & $\begin{array}{c}3.98 \\
(1.47)\end{array}$ & $\begin{array}{c}3.53 \\
(1.33)\end{array}$ & $\begin{array}{c}4.04 \\
(1.31)\end{array}$ & $\begin{array}{c}3.60 \\
(1.16)\end{array}$ & $\begin{array}{c}4.54 \\
(1.43)\end{array}$ & $\begin{array}{c}2.97 \\
(1.08)\end{array}$ & $\begin{array}{c}3.35 \\
(1.25)\end{array}$ & $\begin{array}{c}3.57 \\
(1.35)\end{array}$ & $\begin{array}{c}3.68 \\
(1.38)\end{array}$ & $\begin{array}{c}3.69 \\
(1.39)\end{array}$ & $\begin{array}{c}3.54 \\
(1.34)\end{array}$ \\
\hline grgmtogrsales & $\begin{array}{c}-3.12 \\
(-0.57)\end{array}$ & & & & & & & & & & & & & & \\
\hline grltnoa & & $\begin{array}{c}3.36 \\
(0.41)\end{array}$ & & & & & & & & & & & & & \\
\hline grsaletogrinv & & & $\begin{array}{c}4.98 \\
(0.67)\end{array}$ & & & & & & & & & & & & \\
\hline grsaletogroverhead & & & & $\begin{array}{c}3.83 \\
(0.78)\end{array}$ & & & & & & & & & & & \\
\hline herf & & & & & $\begin{array}{l}-3.87 \\
(-0.70)\end{array}$ & & & & & & & & & & \\
\hline high52 & & & & & & $\begin{array}{c}0.05 \\
(0.03)\end{array}$ & & & & & & & & & \\
\hline io_shortinterest & & & & & & & $\begin{array}{l}-11.03 \\
(-1.44)\end{array}$ & & & & & & & & \\
\hline idiorisk & & & & & & & & $\begin{array}{l}-2.58 \\
(-1.00)\end{array}$ & & & & & & & \\
\hline illiquidity & & & & & & & & & $\begin{array}{c}-3.36 \\
(-0.56)\end{array}$ & & & & & & \\
\hline indipo & & & & & & & & & & $\begin{array}{l}-2.72 \\
(-0.75)\end{array}$ & & & & & \\
\hline indmom & & & & & & & & & & & $\begin{array}{c}1.54 \\
(0.49)\end{array}$ & & & & \\
\hline indretbig & & & & & & & & & & & & $\begin{array}{c}0.72 \\
(0.26)\end{array}$ & & & \\
\hline intmom & & & & & & & & & & & & & $\begin{array}{c}1.12 \\
(0.41)\end{array}$ & & \\
\hline intanbm & & & & & & & & & & & & & & $\begin{array}{l}-2.02 \\
(-0.71)\end{array}$ & \\
\hline intancfp & & & & & & & & & & & & & & & $\begin{array}{c}-3.50 \\
(-0.81)\end{array}$ \\
\hline
\end{tabular}




\begin{tabular}{|c|c|c|c|c|c|c|c|c|c|c|c|c|c|c|c|}
\hline $\begin{array}{l}\text { (Percentage) } \\
\text { VARIABLES }\end{array}$ & $\begin{array}{c}(76) \\
\text { Return }\end{array}$ & $\begin{array}{c}(77) \\
\text { Return }\end{array}$ & $\begin{array}{c}(78) \\
\text { Return }\end{array}$ & $\begin{array}{l}\text { (79) } \\
\text { Return }\end{array}$ & $\begin{array}{l}\quad(80) \\
\text { Return }\end{array}$ & $\begin{array}{l}\quad(81) \\
\text { Return }\end{array}$ & $\begin{array}{c}(82) \\
\text { Return }\end{array}$ & $\begin{array}{l}\text { (83) } \\
\text { Return }\end{array}$ & $\begin{array}{l}\quad(84) \\
\text { Return }\end{array}$ & $\begin{array}{c}(85) \\
\text { Return }\end{array}$ & $\begin{array}{l}\text { (86) } \\
\text { Return }\end{array}$ & $\begin{array}{c}\quad(87) \\
\text { Return }\end{array}$ & $\begin{array}{c}(88) \\
\text { Return }\end{array}$ & $\begin{array}{c}(89) \\
\text { Return }\end{array}$ & $\begin{array}{c}\text { (90) } \\
\text { Return }\end{array}$ \\
\hline mktrf & $\begin{array}{c}3.44 \\
(1.32)\end{array}$ & $\begin{array}{c}3.53 \\
(1.33)\end{array}$ & $\begin{array}{c}3.70 \\
(1.38)\end{array}$ & $\begin{array}{c}3.08 \\
(1.18)\end{array}$ & $\begin{array}{c}3.83 \\
(1.44)\end{array}$ & $\begin{array}{c}3.23 \\
(1.19)\end{array}$ & $\begin{array}{c}3.80 \\
(1.23)\end{array}$ & $\begin{array}{c}3.50 \\
(1.32)\end{array}$ & $\begin{array}{c}3.51 \\
(1.33)\end{array}$ & $\begin{array}{c}3.59 \\
(1.35)\end{array}$ & $\begin{array}{c}3.49 \\
(1.31)\end{array}$ & $\begin{array}{c}3.42 \\
(1.29)\end{array}$ & $\begin{array}{c}3.70 \\
(1.39)\end{array}$ & $\begin{array}{c}3.88 \\
(1.38)\end{array}$ & $\begin{array}{c}3.44 \\
(1.30)\end{array}$ \\
\hline intanep & $\begin{array}{c}-6.79 \\
(-1.33)\end{array}$ & & & & & & & & & & & & & & \\
\hline intansp & & $\begin{array}{c}-0.04 \\
(-0.01)\end{array}$ & & & & & & & & & & & & & \\
\hline investment & & & $\begin{array}{c}-2.91 \\
(-0.34)\end{array}$ & & & & & & & & & & & & \\
\hline $\mathrm{kz}$ & & & & $\begin{array}{l}-9.78^{*} \\
(-1.72)\end{array}$ & & & & & & & & & & & \\
\hline leverage & & & & & $\begin{array}{l}-2.82 \\
(-0.92)\end{array}$ & & & & & & & & & & \\
\hline $\mathrm{ms}$ & & & & & & $\begin{array}{c}1.83 \\
(0.52)\end{array}$ & & & & & & & & & \\
\hline maxret & & & & & & & $\begin{array}{c}-2.37 \\
(-0.83)\end{array}$ & & & & & & & & \\
\hline meanrankrevgrowth & & & & & & & & $\begin{array}{c}1.25 \\
(0.24)\end{array}$ & & & & & & & \\
\hline $\operatorname{mom} 12 \mathrm{~m}$ & & & & & & & & & $\begin{array}{c}0.86 \\
(0.42)\end{array}$ & & & & & & \\
\hline $\operatorname{mom} 18 \mathrm{~m} 13 \mathrm{~m}$ & & & & & & & & & & $\begin{array}{c}-0.74 \\
(-0.22)\end{array}$ & & & & & \\
\hline $\operatorname{mom} 1 \mathrm{~m}$ & & & & & & & & & & & $\begin{array}{c}-0.49 \\
(-0.18)\end{array}$ & & & & \\
\hline $\operatorname{mom} 36 \mathrm{~m}$ & & & & & & & & & & & & $\begin{array}{l}1.02 \\
(0.40)\end{array}$ & & & \\
\hline $\operatorname{mom} 6 \mathrm{~m}$ & & & & & & & & & & & & & $\begin{array}{l}-1.48 \\
(-0.50)\end{array}$ & & \\
\hline mom6mjunk & & & & & & & & & & & & & & $\begin{array}{c}-0.80 \\
(-0.29)\end{array}$ & \\
\hline momrev & & & & & & & & & & & & & & & $\begin{array}{l}-1.30 \\
(-0.70)\end{array}$ \\
\hline
\end{tabular}




\begin{tabular}{|c|c|c|c|c|c|c|c|c|c|c|c|c|c|c|c|}
\hline (Percentage) & $(91)$ & $(92)$ & $(93)$ & $(94)$ & $(95)$ & $(96)$ & $(97)$ & $(98)$ & $(99)$ & $(100)$ & (101) & $(102)$ & (103) & (104) & (105) \\
\hline VARIABLES & Return & Return & Return & Return & Return & Return & Return & Return & Return & Return & Return & Return & Return & Return & Return \\
\hline mktrf & $\begin{array}{c}3.77 \\
(1.36)\end{array}$ & $\begin{array}{c}3.55 \\
(1.34)\end{array}$ & $\begin{array}{c}3.67 \\
(1.37)\end{array}$ & $\begin{array}{c}3.53 \\
(1.33)\end{array}$ & $\begin{array}{c}3.73 \\
(1.40)\end{array}$ & $\begin{array}{c}3.31 \\
(1.24)\end{array}$ & $\begin{array}{c}3.34 \\
(1.25)\end{array}$ & $\begin{array}{c}3.50 \\
(1.32)\end{array}$ & $\begin{array}{l}4.50^{*} \\
(1.72)\end{array}$ & $\begin{array}{c}2.97 \\
(1.10)\end{array}$ & $\begin{array}{c}3.33 \\
(1.25)\end{array}$ & $\begin{array}{c}4.11 \\
(1.45)\end{array}$ & $\begin{array}{c}3.83 \\
(1.35)\end{array}$ & $\begin{array}{c}2.88 \\
(1.08)\end{array}$ & $\begin{array}{c}3.56 \\
(1.37)\end{array}$ \\
\hline momseas & $\begin{array}{c}-1.34 \\
(-0.30)\end{array}$ & & & & & & & & & & & & & & \\
\hline momvol & & $\begin{array}{c}-0.59 \\
(-0.35)\end{array}$ & & & & & & & & & & & & & \\
\hline noa & & & $\begin{array}{c}-1.46 \\
(-0.37)\end{array}$ & & & & & & & & & & & & \\
\hline netdebtfinance & & & & $\begin{array}{l}-1.76 \\
(-0.20)\end{array}$ & & & & & & & & & & & \\
\hline netdebtprice & & & & & $\begin{array}{c}-1.40 \\
(-0.51)\end{array}$ & & & & & & & & & & \\
\hline netequityfinance & & & & & & $\begin{array}{c}-1.92 \\
(-0.56)\end{array}$ & & & & & & & & & \\
\hline netpayoutyield & & & & & & & $\begin{array}{c}-1.62 \\
(-0.58)\end{array}$ & & & & & & & & \\
\hline numearnincrease & & & & & & & & $\begin{array}{c}-0.87 \\
(-0.13)\end{array}$ & & & & & & & \\
\hline opleverage & & & & & & & & & $\begin{array}{l}9.28^{*} \\
(1.97)\end{array}$ & & & & & & \\
\hline oscore & & & & & & & & & & $\begin{array}{c}-3.90 \\
(-0.97)\end{array}$ & & & & & \\
\hline operprof & & & & & & & & & & & $\begin{array}{c}-2.58 \\
(-0.68)\end{array}$ & & & & \\
\hline optionvolume1 & & & & & & & & & & & & $\begin{array}{c}-5.14 \\
(-0.91)\end{array}$ & & & \\
\hline optionvolume2 & & & & & & & & & & & & & $\begin{array}{c}0.54 \\
(0.05)\end{array}$ & & \\
\hline orderbacklog & & & & & & & & & & & & & & $\begin{array}{c}-7.08 \\
(-1.28)\end{array}$ & \\
\hline orgcap & & & & & & & & & & & & & & & $\begin{array}{c}2.99 \\
(1.53)\end{array}$ \\
\hline
\end{tabular}




\begin{tabular}{|c|c|c|c|c|c|c|c|c|c|c|c|c|c|c|c|}
\hline (Percentage) & (106) & (107) & (108) & (109) & (110) & (111) & (112) & (113) & (114) & (115) & (116) & (117) & (118) & (119) & (120) \\
\hline VARIABLES & Return & Return & Return & Return & Return & Return & Return & Return & Return & Return & Return & Return & Return & Return & Return \\
\hline mktrf & $\begin{array}{c}3.18 \\
(1.20)\end{array}$ & $\begin{array}{c}3.55 \\
(1.34)\end{array}$ & $\begin{array}{c}3.58 \\
(1.36)\end{array}$ & $\begin{array}{c}3.47 \\
(1.31)\end{array}$ & $\begin{array}{c}3.59 \\
(1.399\end{array}$ & $\begin{array}{c}3.48 \\
(1.30)\end{array}$ & $\begin{array}{c}4.17 \\
(1.37)\end{array}$ & $\begin{array}{c}3.20 \\
(1.19)\end{array}$ & $\begin{array}{c}3.54 \\
(1.34)\end{array}$ & $\begin{array}{c}3.08 \\
(1.15)\end{array}$ & $\begin{array}{c}3.18 \\
(1.19)\end{array}$ & $\begin{array}{c}3.60 \\
(1.36)\end{array}$ & $\begin{array}{c}3.45 \\
(1.31)\end{array}$ & $\begin{array}{c}3.45 \\
(1.30)\end{array}$ & $\begin{array}{c}4.42 \\
(1.43)\end{array}$ \\
\hline $\mathrm{pm}$ & $\begin{array}{c}-3.20 \\
(-0.90)\end{array}$ & & & & & & & & & & & & & & \\
\hline ps & & $\begin{array}{c}-0.68 \\
(-0.27)\end{array}$ & & & & & & & & & & & & & \\
\hline payoutyield & & & $\begin{array}{c}-3.27 \\
(-0.64)\end{array}$ & & & & & & & & & & & & \\
\hline pctacc & & & & $\begin{array}{c}2.24 \\
(0.30)\end{array}$ & & & & & & & & & & & \\
\hline pcttotacc & & & & & $\begin{array}{l}14.32^{*} \\
(1.90)\end{array}$ & & & & & & & & & & \\
\hline price & & & & & & $\begin{array}{c}0.30 \\
(0.14)\end{array}$ & & & & & & & & & \\
\hline pricedelay & & & & & & & $\begin{array}{c}-1.41 \\
(-0.11)\end{array}$ & & & & & & & & \\
\hline profitability & & & & & & & & $\begin{array}{c}-1.88 \\
(-0.72)\end{array}$ & & & & & & & \\
\hline $\mathrm{rd}$ & & & & & & & & & $\begin{array}{c}2.85 \\
(0.89)\end{array}$ & & & & & & \\
\hline rdipo & & & & & & & & & & $\begin{array}{c}-5.19 \\
(-1.01)\end{array}$ & & & & & \\
\hline rds & & & & & & & & & & & $\begin{array}{c}2.76 \\
(0.76)\end{array}$ & & & & \\
\hline rev6 & & & & & & & & & & & & $\begin{array}{c}-1.69 \\
(-0.34)\end{array}$ & & & \\
\hline rio_bm & & & & & & & & & & & & & $\begin{array}{c}3.70 \\
(0.95)\end{array}$ & & \\
\hline rio_disp & & & & & & & & & & & & & & $\begin{array}{c}1.44 \\
(0.41)\end{array}$ & \\
\hline rio_idiorisk & & & & & & & & & & & & & & & $\begin{array}{c}-3.24 \\
(-0.72)\end{array}$ \\
\hline
\end{tabular}




\begin{tabular}{|c|c|c|c|c|c|c|c|c|c|c|c|c|c|c|c|}
\hline (Percentage) & $(121)$ & $(122)$ & (123) & $(124)$ & (125) & (126) & $(127)$ & (128) & (129) & (130) & $(131)$ & (132) & (133) & (134) & (135) \\
\hline VARIABLES & Return & Return & Return & Return & Return & Return & Return & Return & Return & Return & Return & Return & Return & Return & Return \\
\hline mktrf & $\begin{array}{c}3.56 \\
(1.33)\end{array}$ & $\begin{array}{c}3.54 \\
(1.34)\end{array}$ & $\begin{array}{c}3.53 \\
(1.28)\end{array}$ & $\begin{array}{c}3.33 \\
(1.27)\end{array}$ & $\begin{array}{c}3.53 \\
(1.33)\end{array}$ & $\begin{array}{c}3.34 \\
(1.25)\end{array}$ & $\begin{array}{c}3.58 \\
(1.36)\end{array}$ & $\begin{array}{c}3.24 \\
(1.21)\end{array}$ & $\begin{array}{c}3.36 \\
(1.28)\end{array}$ & $\begin{array}{c}3.91 \\
(1.45)\end{array}$ & $\begin{array}{c}3.48 \\
(1.27)\end{array}$ & $\begin{array}{c}3.69 \\
(1.31)\end{array}$ & $\begin{array}{c}3.55 \\
(1.26)\end{array}$ & $\begin{array}{c}3.46 \\
(1.30)\end{array}$ & $\begin{array}{c}3.55 \\
(1.34)\end{array}$ \\
\hline rio_turnover & $\begin{array}{c}-0.21 \\
(-0.08)\end{array}$ & & & & & & & & & & & & & & \\
\hline revenuesurprise & & $\begin{array}{c}0.89 \\
(0.13)\end{array}$ & & & & & & & & & & & & & \\
\hline roe & & & $\begin{array}{c}0.02 \\
(0.00)\end{array}$ & & & & & & & & & & & & \\
\hline seo & & & & $\begin{array}{c}-5.36 \\
(-1.39)\end{array}$ & & & & & & & & & & & \\
\hline sp & & & & & $\begin{array}{c}-0.03 \\
(-0.01)\end{array}$ & & & & & & & & & & \\
\hline shareiss1y & & & & & & $\begin{array}{c}-2.08 \\
(-0.54)\end{array}$ & & & & & & & & & \\
\hline shareiss5y & & & & & & & $\begin{array}{c}4.16 \\
(0.64)\end{array}$ & & & & & & & & \\
\hline sharerepurchase & & & & & & & & $\begin{array}{c}-3.34 \\
(-0.57)\end{array}$ & & & & & & & \\
\hline sharevol & & & & & & & & & $\begin{array}{c}-3.55 \\
(-1.28)\end{array}$ & & & & & & \\
\hline shortinterest & & & & & & & & & & $\begin{array}{c}-1.79 \\
(-0.68)\end{array}$ & & & & & \\
\hline size & & & & & & & & & & & $\begin{array}{c}0.19 \\
(0.07)\end{array}$ & & & & \\
\hline skew1 & & & & & & & & & & & & $\begin{array}{c}-8.17 \\
(-0.86)\end{array}$ & & & \\
\hline smileslope & & & & & & & & & & & & & $\begin{array}{l}-4.39 \\
(-1.09)\end{array}$ & & \\
\hline spinoff & & & & & & & & & & & & & & $\begin{array}{c}0.96 \\
(0.27)\end{array}$ & \\
\hline surpriserd & & & & & & & & & & & & & & & $\begin{array}{c}3.13 \\
(0.54)\end{array}$ \\
\hline
\end{tabular}




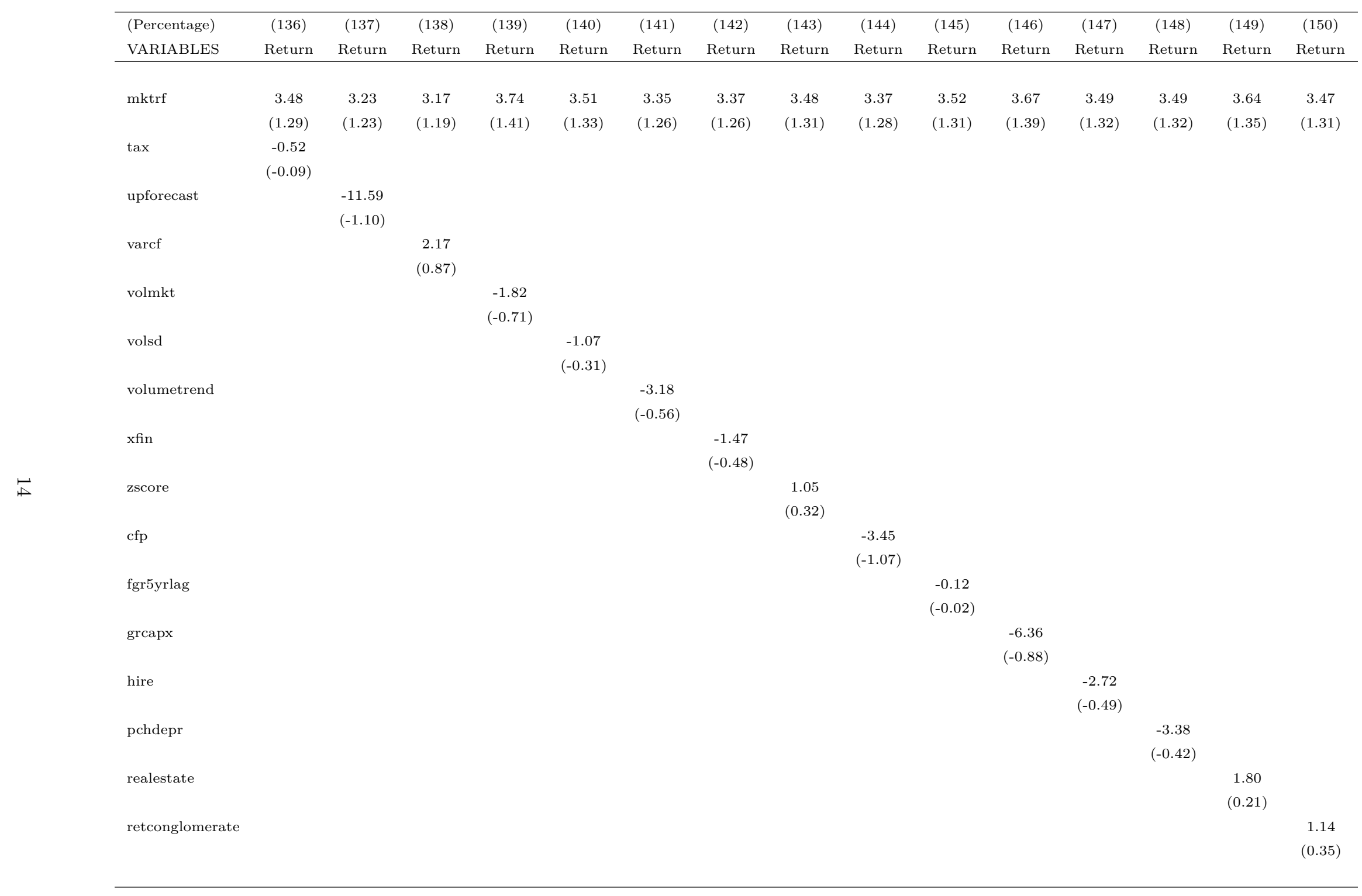




\begin{tabular}{|c|c|c|c|c|c|}
\hline (Percentage) & (151) & (152) & (153) & (154) & (155) \\
\hline VARIABLES & Return & Return & Return & Return & Return \\
\hline \multirow[t]{2}{*}{ mktrf } & 2.71 & 3.49 & 3.58 & 3.41 & 4.37 \\
\hline & (1.02) & $(1.32)$ & $(1.36)$ & (1.29) & $(1.40)$ \\
\hline \multirow[t]{2}{*}{ sfe } & 4.03 & & & & \\
\hline & $(1.60)$ & & & & \\
\hline \multirow[t]{2}{*}{ sinalgo } & & 1.35 & & & \\
\hline & & $(0.40)$ & & & \\
\hline \multirow[t]{2}{*}{ std_turn } & & & -2.15 & & \\
\hline & & & $(-0.91)$ & & \\
\hline \multirow[t]{2}{*}{ tang } & & & & 0.90 & \\
\hline & & & & $(0.68)$ & \\
\hline \multirow[t]{2}{*}{ zerotrade } & & & & & -1.65 \\
\hline & & & & & $(-0.56)$ \\
\hline \multirow[t]{2}{*}{ Constant } & $24.18^{* *}$ & $19.34^{* *}$ & $22.21^{* *}$ & $19.49^{* *}$ & $23.17^{* *}$ \\
\hline & $(2.47)$ & $(2.04)$ & $(2.24)$ & $(2.06)$ & $(2.05)$ \\
\hline Observations & 71 & 71 & 71 & 71 & 60 \\
\hline R-squared & 0.0608 & 0.0279 & 0.0372 & 0.0320 & 0.0357 \\
\hline
\end{tabular}


Table A.4: Other Predictors

\begin{tabular}{|c|c|c|c|c|c|c|}
\hline Panel A: Bitcoin & (1) & (2) & (3) & (4) & (5) & (6) \\
\hline \multirow[t]{2}{*}{$\mathrm{pd}$} & 0.03 & & & & & 0.01 \\
\hline & $(0.97)$ & & & & & $(0.24)$ \\
\hline \multirow[t]{2}{*}{ pe } & & -0.02 & & & & -0.02 \\
\hline & & $(-0.98)$ & & & & $(-0.67)$ \\
\hline \multirow[t]{2}{*}{ credit } & & & -0.14 & & & -0.06 \\
\hline & & & $(-0.47)$ & & & $(-0.15)$ \\
\hline \multirow[t]{2}{*}{ term } & & & & $0.24^{*}$ & & 0.11 \\
\hline & & & & $(1.92)$ & & $(0.55)$ \\
\hline \multirow[t]{2}{*}{ tbill } & & & & & 0.31 & 0.35 \\
\hline & & & & & $(1.18)$ & $(1.16)$ \\
\hline R-squared & 0.00 & 0.00 & 0.00 & 0.01 & 0.04 & 0.06 \\
\hline Panel B: Ripple & $(1)$ & $(2)$ & $(3)$ & $(4)$ & $(5)$ & (6) \\
\hline \multirow[t]{2}{*}{$\mathrm{pd}$} & 0.07 & & & & & 0.09 \\
\hline & $(0.87)$ & & & & & $(0.62)$ \\
\hline \multirow[t]{2}{*}{ pe } & & 0.04 & & & & -0.15 \\
\hline & & $(0.48)$ & & & & $(-0.57)$ \\
\hline \multirow[t]{2}{*}{ credit } & & & -0.94 & & & -0.07 \\
\hline & & & $(-1.15)$ & & & $(-0.04)$ \\
\hline \multirow[t]{2}{*}{ term } & & & & -0.26 & & -1.08 \\
\hline & & & & $(-0.74)$ & & $(-1.00)$ \\
\hline \multirow[t]{2}{*}{ tbill } & & & & & 0.12 & 0.83 \\
\hline & & & & & $(0.14)$ & $(0.70)$ \\
\hline R-squared & 0.01 & 0.00 & 0.02 & 0.01 & 0.0 & 0.07 \\
\hline Panel C: Ethereum & $(1)$ & $(2)$ & (3) & $(4)$ & (5) & (6) \\
\hline \multirow[t]{2}{*}{$\mathrm{pd}$} & -0.02 & & & & & 0.05 \\
\hline & $(-0.48)$ & & & & & $(0.51)$ \\
\hline \multirow[t]{2}{*}{ pe } & & -0.08 & & & & -0.02 \\
\hline & & $(-0.45)$ & & & & $(-0.09)$ \\
\hline \multirow[t]{2}{*}{ credit } & & & 0.19 & & & -0.13 \\
\hline & & & $(0.44)$ & & & $(-0.12)$ \\
\hline \multirow[t]{2}{*}{ term } & & & & 0.43 & & 0.60 \\
\hline & & & & $(1.28)$ & & $(0.82)$ \\
\hline \multirow[t]{2}{*}{ tbill } & & & & & -0.10 & -0.24 \\
\hline & & & & & $(-0.21)$ & $(-0.28)$ \\
\hline R-squared & 0.01 & 0.01 & 0.01 & 0.05 & 0.00 & 0.05 \\
\hline
\end{tabular}


Table A.5: Detailed U.S. SIC 3-digit Industry Exposures to Bitcoin Returns

\begin{tabular}{|c|c|c|c|c|c|c|c|c|c|c|c|c|c|c|c|}
\hline SIC CODE & 0 & 11 & 17 & 18 & 19 & 20 & 25 & 70 & 72 & 74 & 76 & 78 & 83 & 91 & 99 \\
\hline BITCOIN & $\begin{array}{l}-2.16 \\
(-1.50)\end{array}$ & $\begin{array}{c}-0.70 \\
(-0.55)\end{array}$ & $\begin{array}{l}-1.12 \\
(-0.83)\end{array}$ & $\begin{array}{c}-0.97 \\
(-0.87)\end{array}$ & $\begin{array}{c}1.53 \\
(0.97)\end{array}$ & $\begin{array}{c}0.85 \\
(0.13)\end{array}$ & $\begin{array}{l}-1.61 \\
(-1.45)\end{array}$ & $\begin{array}{c}-0.37 \\
(-0.33)\end{array}$ & $\begin{array}{c}-0.65 \\
(-0.67)\end{array}$ & $\begin{array}{l}-1.20 \\
(-1.23)\end{array}$ & $\begin{array}{c}1.28 \\
(0.59)\end{array}$ & $\begin{array}{c}-3.04 \\
(-0.53)\end{array}$ & $\begin{array}{l}-5.57^{*} \\
(-2.07)\end{array}$ & $\begin{array}{c}0.01 \\
(0.00)\end{array}$ & $\begin{array}{l}-2.50 \\
(-1.21)\end{array}$ \\
\hline MKTRF & $\begin{array}{c}1.89^{* * *} \\
(5.68)\end{array}$ & $\begin{array}{c}1.05^{* * *} \\
(3.74)\end{array}$ & $\begin{array}{c}1.39^{* * *} \\
(4.68)\end{array}$ & $\begin{array}{c}1.01^{* * *} \\
(4.05)\end{array}$ & $\begin{array}{c}1.46^{* * *} \\
(4.22)\end{array}$ & $\begin{array}{l}2.31^{* *} \\
(2.10)\end{array}$ & $\begin{array}{c}0.64^{* *} \\
(2.62)\end{array}$ & $\begin{array}{c}0.77^{* * *} \\
(3.12)\end{array}$ & $\begin{array}{c}1.16^{* * *} \\
(5.46)\end{array}$ & $\begin{array}{c}1.41^{* * *} \\
(6.56)\end{array}$ & $\begin{array}{c}2.07^{* * *} \\
(4.29)\end{array}$ & $\begin{array}{l}1.01^{* *} \\
(2.22)\end{array}$ & $\begin{array}{l}1.59^{* *} \\
(2.29)\end{array}$ & $\begin{array}{c}0.21 \\
(0.54)\end{array}$ & $\begin{array}{c}2.32^{* * * *} \\
(4.10)\end{array}$ \\
\hline SIC CODE & 100 & 101 & 102 & 103 & 104 & 106 & 107 & 108 & 109 & 122 & 124 & 131 & 132 & 138 & 140 \\
\hline BITCOIN & $\begin{array}{c}-0.76 \\
(-0.52)\end{array}$ & $\begin{array}{c}-1.30 \\
(-0.85)\end{array}$ & $\begin{array}{l}-2.61^{*} \\
(-1.89)\end{array}$ & $\begin{array}{l}-3.32^{* *} \\
(-2.61)\end{array}$ & $\begin{array}{c}-1.40 \\
(-0.85)\end{array}$ & $\begin{array}{l}-6.47^{* *} \\
(-2.18)\end{array}$ & $\begin{array}{l}-0.03 \\
(-0.01)\end{array}$ & $\begin{array}{c}1.69 \\
(0.76)\end{array}$ & $\begin{array}{l}-0.87 \\
(-0.69)\end{array}$ & $\begin{array}{l}-1.21 \\
(-0.85)\end{array}$ & $\begin{array}{c}1.81 \\
(0.38)\end{array}$ & $\begin{array}{l}-1.06 \\
(-1.34)\end{array}$ & $\begin{array}{l}-0.75 \\
(-0.62)\end{array}$ & $\begin{array}{l}-1.39 \\
(-1.55)\end{array}$ & $\begin{array}{c}1.65 \\
(0.66)\end{array}$ \\
\hline MKTRF & $\begin{array}{c}1.57^{* * *} \\
(4.90)\end{array}$ & $\begin{array}{c}1.61^{* * *} \\
(4.77)\end{array}$ & $\begin{array}{c}1.73^{* * *} \\
(5.66)\end{array}$ & $\begin{array}{c}1.67^{* * *} \\
(5.96)\end{array}$ & $\begin{array}{c}0.53 \\
(1.45)\end{array}$ & $\begin{array}{c}2.34^{* * *} \\
(3.56)\end{array}$ & $\begin{array}{c}2.80^{* * *} \\
(3.95)\end{array}$ & $\begin{array}{c}1.56^{* * *} \\
(3.17)\end{array}$ & $\begin{array}{c}2.06^{* * *} \\
(7.36)\end{array}$ & $\begin{array}{c}1.58^{* * *} \\
(5.03)\end{array}$ & $\begin{array}{c}2.87^{* * *} \\
(3.03)\end{array}$ & $\begin{array}{c}1.50^{* * *} \\
(8.59)\end{array}$ & $\begin{array}{c}1.71^{* * *} \\
(6.38)\end{array}$ & $\begin{array}{c}1.61^{* * *} \\
(8.10)\end{array}$ & $\begin{array}{l}0.97^{*} \\
(1.77)\end{array}$ \\
\hline SIC CODE & 141 & 142 & 144 & 147 & 148 & 149 & 152 & 153 & 154 & 160 & 161 & 162 & 170 & 171 & 173 \\
\hline BITCOIN & $\begin{array}{c}2.02 \\
(1.08)\end{array}$ & $\begin{array}{c}-2.39 \\
(-1.35)\end{array}$ & $\begin{array}{c}-0.42 \\
(-0.41)\end{array}$ & $\begin{array}{c}-0.14 \\
(-0.14)\end{array}$ & $\begin{array}{c}5.09 \\
(0.49)\end{array}$ & $\begin{array}{c}-1.24 \\
(-0.82)\end{array}$ & $\begin{array}{c}-0.94 \\
(-0.83)\end{array}$ & $\begin{array}{c}-0.04 \\
(-0.06)\end{array}$ & $\begin{array}{c}-0.99 \\
(-0.75)\end{array}$ & $\begin{array}{c}-0.81 \\
(-0.57)\end{array}$ & $\begin{array}{c}-2.14 \\
(-0.49)\end{array}$ & $\begin{array}{l}-1.11 \\
(-1.56)\end{array}$ & $\begin{array}{l}-4.21 \\
(-0.95)\end{array}$ & $\begin{array}{l}-1.22 \\
(-1.02)\end{array}$ & $\begin{array}{l}-0.69 \\
(-1.20)\end{array}$ \\
\hline MKTRF & $\begin{array}{l}1.06 * * \\
(2.55) \\
\end{array}$ & $\begin{array}{c}1.45^{* * *} \\
(4.05) \\
\end{array}$ & $\begin{array}{c}1.13^{* * *} \\
(5.87) \\
\end{array}$ & $\begin{array}{c}0.88^{* * *} \\
(3.79) \\
\end{array}$ & $\begin{array}{c}1.42^{*} \\
(1.76) \\
\end{array}$ & $\begin{array}{c}1.13^{* * *} \\
(3.37) \\
\end{array}$ & $\begin{array}{c}1.73^{* * *} \\
(6.95) \\
\end{array}$ & $\begin{array}{c}1.42^{* * *} \\
(8.20) \\
\end{array}$ & $\begin{array}{c}2.46^{* * *} \\
(8.40) \\
\end{array}$ & $\begin{array}{c}1.36^{* * *} \\
(4.35) \\
\end{array}$ & $\begin{array}{c}4.01^{* * *} \\
(4.18) \\
\end{array}$ & $\begin{array}{l}1.71^{* * *} \\
(10.80) \\
\end{array}$ & $\begin{array}{l}1.76^{*} \\
(1.80) \\
\end{array}$ & $\begin{array}{c}1.58^{* * * *} \\
(5.98) \\
\end{array}$ & $\begin{array}{c}0.92^{* * * *} \\
(7.21) \\
\end{array}$ \\
\hline SIC CODE & 174 & 175 & 178 & 179 & 200 & 201 & 202 & 203 & 204 & 205 & 206 & 207 & 208 & 209 & 210 \\
\hline BITCOIN & $\begin{array}{c}-1.78 \\
(-0.29)\end{array}$ & $\begin{array}{l}-4.55 \\
(-0.71)\end{array}$ & $\begin{array}{l}-3.45^{*} \\
(-1.93)\end{array}$ & $\begin{array}{c}1.35 \\
(0.79)\end{array}$ & $\begin{array}{c}0.44 \\
(0.46)\end{array}$ & $\begin{array}{c}0.73 \\
(1.07)\end{array}$ & $\begin{array}{c}0.83 \\
(0.96)\end{array}$ & $\begin{array}{c}-0.30 \\
(-0.53)\end{array}$ & $\begin{array}{c}0.32 \\
(0.67)\end{array}$ & $\begin{array}{c}-0.19 \\
(-0.27)\end{array}$ & $\begin{array}{c}1.09 \\
(1.51)\end{array}$ & $\begin{array}{c}-0.20 \\
(-0.34)\end{array}$ & $\begin{array}{c}0.43 \\
(0.96)\end{array}$ & $\begin{array}{c}1.48 \\
(1.09)\end{array}$ & $\begin{array}{c}232.74 \\
(1.36)\end{array}$ \\
\hline MKTRF & $\begin{array}{c}0.82 \\
(1.65) \\
\end{array}$ & $\begin{array}{c}4.73^{* * * *} \\
(4.73) \\
\end{array}$ & $\begin{array}{c}0.82^{* *} \\
(2.07) \\
\end{array}$ & $\begin{array}{c}1.67^{* * *} \\
(4.22) \\
\end{array}$ & $\begin{array}{c}0.55^{* * *} \\
(2.65) \\
\end{array}$ & $\begin{array}{c}0.49^{* * *} \\
(3.23) \\
\end{array}$ & $\begin{array}{c}0.95^{* * *} \\
(4.98)\end{array}$ & $\begin{array}{c}0.41^{* * *} \\
(3.30) \\
\end{array}$ & $\begin{array}{c}0.50^{* * * *} \\
(4.72) \\
\end{array}$ & $\begin{array}{c}0.64^{* * *} \\
(4.06) \\
\end{array}$ & $\begin{array}{c}0.41^{* *} \\
(2.58) \\
\end{array}$ & $\begin{array}{c}0.78^{* * *} \\
(6.08) \\
\end{array}$ & $\begin{array}{c}0.53^{* * *} \\
(5.37) \\
\end{array}$ & $\begin{array}{c}0.47 \\
(1.55) \\
\end{array}$ & $\begin{array}{l}-12.55 \\
(-1.63) \\
\end{array}$ \\
\hline SIC CODE & 211 & 213 & 220 & 221 & 222 & 225 & 227 & 228 & 229 & 230 & 231 & 232 & 233 & 234 & 238 \\
\hline BITCOIN & $\begin{array}{l}-0.20 \\
(-0.32)\end{array}$ & $\begin{array}{c}-0.68 \\
(-0.26)\end{array}$ & $\begin{array}{c}2.97 \\
(0.27)\end{array}$ & $\begin{array}{c}0.08 \\
(0.08)\end{array}$ & $\begin{array}{c}-0.83 \\
(-1.01)\end{array}$ & $\begin{array}{c}-0.02 \\
(-0.02)\end{array}$ & $\begin{array}{c}-0.34 \\
(-0.46)\end{array}$ & $\begin{array}{c}1.39 \\
(1.01)\end{array}$ & $\begin{array}{c}0.45 \\
(0.26)\end{array}$ & $\begin{array}{c}0.57 \\
(0.36)\end{array}$ & $\begin{array}{c}11.30^{* *} \\
(2.16)\end{array}$ & $\begin{array}{c}0.21 \\
(0.35)\end{array}$ & $\begin{array}{l}1.73^{*} \\
(1.75)\end{array}$ & $\begin{array}{c}-0.53 \\
(-0.55)\end{array}$ & $\begin{array}{c}1.52 \\
(0.84)\end{array}$ \\
\hline MKTRF & $\begin{array}{c}0.54^{* * *} \\
(3.84)\end{array}$ & $\begin{array}{c}0.24 \\
(0.20)\end{array}$ & $\begin{array}{c}-0.53 \\
(-0.21)\end{array}$ & $\begin{array}{c}0.62^{* * *} \\
(3.07)\end{array}$ & $\begin{array}{l}1.82^{* * *} \\
(10.06)\end{array}$ & $\begin{array}{c}1.08^{* * *} \\
(5.08)\end{array}$ & $\begin{array}{c}1.39^{* * *} \\
(8.46)\end{array}$ & $\begin{array}{c}1.00^{* * *} \\
(3.29)\end{array}$ & $\begin{array}{c}1.28^{* * *} \\
(3.37)\end{array}$ & $\begin{array}{c}0.20 \\
(0.56)\end{array}$ & $\begin{array}{l}2.37^{* *} \\
(2.31)\end{array}$ & $\begin{array}{c}0.76^{* * *} \\
(5.83)\end{array}$ & $\begin{array}{c}1.12^{* * *} \\
(5.15)\end{array}$ & $\begin{array}{c}0.66^{* * *} \\
(3.09)\end{array}$ & $\begin{array}{c}1.24^{* * *} \\
(3.08)\end{array}$ \\
\hline
\end{tabular}




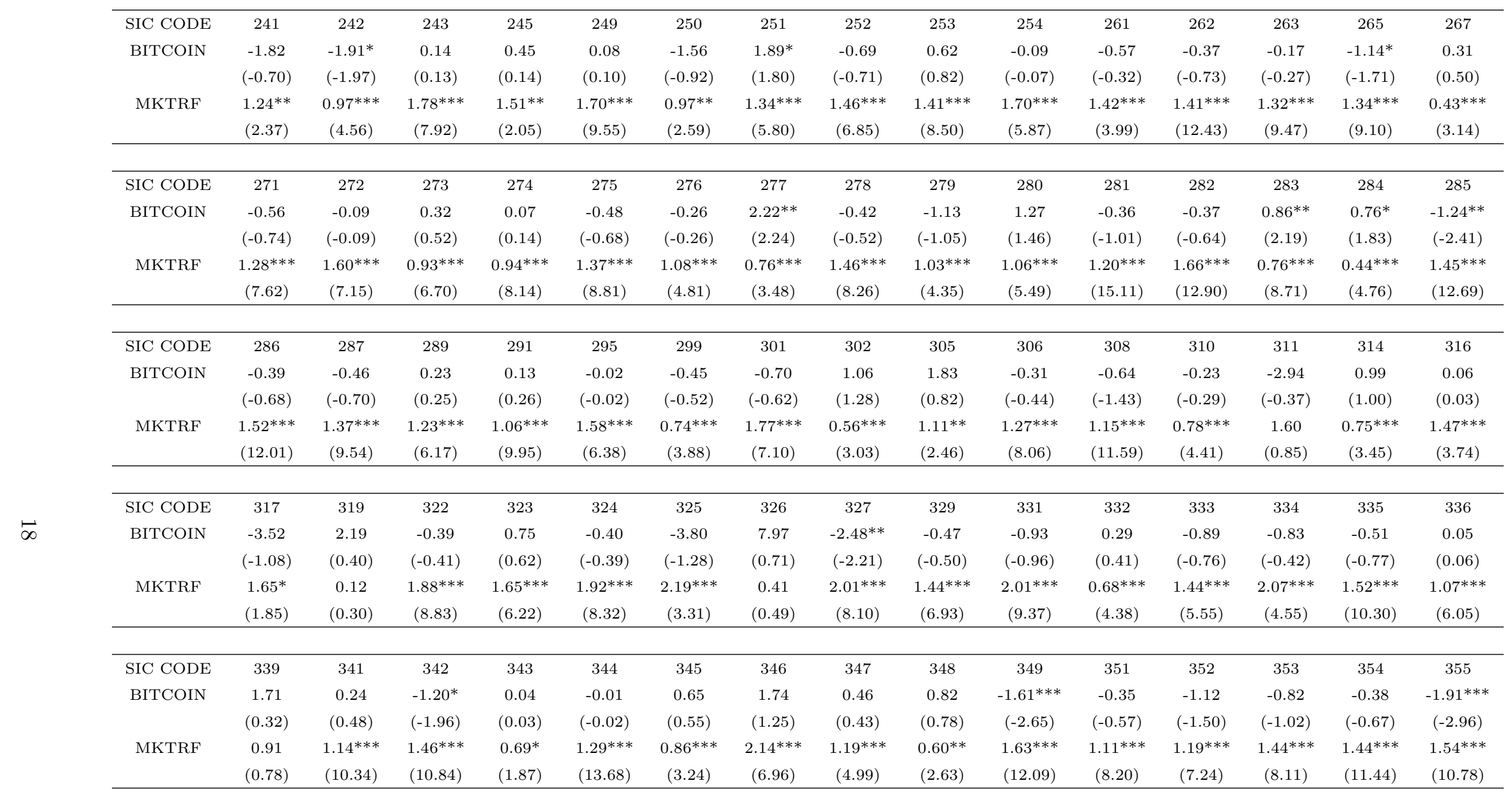




\begin{tabular}{|c|c|c|c|c|c|c|c|c|c|c|c|c|c|c|c|}
\hline SIC CODE & 356 & 357 & 358 & 359 & 360 & 361 & 362 & 363 & 364 & 365 & 366 & 367 & 369 & 371 & 372 \\
\hline BITCOIN & $\begin{array}{l}-0.64 \\
(-1.32)\end{array}$ & $\begin{array}{c}0.12 \\
(0.18)\end{array}$ & $\begin{array}{l}-0.53 \\
(-0.90)\end{array}$ & $\begin{array}{l}-1.12 \\
(-1.38)\end{array}$ & $\begin{array}{c}0.57 \\
(0.50)\end{array}$ & $\begin{array}{c}0.98 \\
(1.64)\end{array}$ & $\begin{array}{l}-0.82 \\
(-1.62)\end{array}$ & $\begin{array}{l}-0.67 \\
(-0.79)\end{array}$ & $\begin{array}{l}-0.65 \\
(-1.10)\end{array}$ & $\begin{array}{l}-1.22 \\
(-1.38)\end{array}$ & $\begin{array}{c}0.61 \\
(0.89)\end{array}$ & $\begin{array}{c}-0.60 \\
(-1.29)\end{array}$ & $\begin{array}{c}0.37 \\
(0.93)\end{array}$ & $\begin{array}{l}-0.64 \\
(-1.15)\end{array}$ & $\begin{array}{c}0.33 \\
(0.87)\end{array}$ \\
\hline MKTRF & $\begin{array}{l}1.40^{* * *} \\
(13.04) \\
\end{array}$ & $\begin{array}{c}1.05^{* * *} \\
(7.21)\end{array}$ & $\begin{array}{l}1.33^{* * *} \\
(10.20)\end{array}$ & $\begin{array}{c}1.70^{* * *} \\
(9.45)\end{array}$ & $\begin{array}{c}1.57^{* * *} \\
(6.25) \\
\end{array}$ & $\begin{array}{c}1.23^{* * *} \\
(9.32) \\
\end{array}$ & $\begin{array}{l}1.39^{* * *} \\
(12.52)\end{array}$ & $\begin{array}{c}1.49^{* * *} \\
(7.91) \\
\end{array}$ & $\begin{array}{c}1.20^{* * *} \\
(9.12) \\
\end{array}$ & $\begin{array}{c}1.75^{* * *} \\
(8.92) \\
\end{array}$ & $\begin{array}{c}1.19^{* * *} \\
(7.92) \\
\end{array}$ & $\begin{array}{l}1.22^{* * *} \\
(11.85) \\
\end{array}$ & $\begin{array}{c}1.13^{* * *} \\
(13.03) \\
\end{array}$ & $\begin{array}{l}1.50^{* * *} \\
(12.29) \\
\end{array}$ & $\begin{array}{l}1.06^{* * *} \\
(12.51) \\
\end{array}$ \\
\hline SIC CODE & 373 & 374 & 375 & 376 & 379 & 381 & 382 & 384 & 385 & 386 & 387 & 391 & 393 & 394 & 395 \\
\hline BITCOIN & $\begin{array}{l}-0.45 \\
(-0.51)\end{array}$ & $\begin{array}{l}-0.83 \\
(-0.90)\end{array}$ & $\begin{array}{l}-1.15 \\
(-1.17)\end{array}$ & $\begin{array}{c}0.72 \\
(0.86)\end{array}$ & $\begin{array}{c}0.03 \\
(0.02)\end{array}$ & $\begin{array}{c}0.15 \\
(0.35)\end{array}$ & $\begin{array}{l}-0.00 \\
(-0.01)\end{array}$ & $\begin{array}{c}0.31 \\
(0.89)\end{array}$ & $\begin{array}{c}0.57 \\
(0.78)\end{array}$ & $\begin{array}{c}0.35 \\
(0.46)\end{array}$ & $\begin{array}{l}-0.84 \\
(-0.46)\end{array}$ & $\begin{array}{c}2.70 \\
(1.62)\end{array}$ & $\begin{array}{c}1.70 \\
(1.33)\end{array}$ & $\begin{array}{c}0.31 \\
(0.46)\end{array}$ & $\begin{array}{c}0.59 \\
(0.34)\end{array}$ \\
\hline MKTRF & $\begin{array}{c}0.98^{* * *} \\
(4.99)\end{array}$ & $\begin{array}{c}1.72^{* * *} \\
(8.43)\end{array}$ & $\begin{array}{c}1.01^{* * *} \\
(4.62)\end{array}$ & $\begin{array}{l}0.36^{*} \\
(1.97)\end{array}$ & $\begin{array}{c}1.37^{* * *} \\
(5.30)\end{array}$ & $\begin{array}{c}0.85^{* * *} \\
(8.97)\end{array}$ & $\begin{array}{l}1.18^{* * *} \\
(13.38)\end{array}$ & $\begin{array}{l}0.89^{* * *} \\
(11.45) \\
\end{array}$ & $\begin{array}{c}0.35^{* *} \\
(2.14)\end{array}$ & $\begin{array}{c}0.98^{* * *} \\
(5.85)\end{array}$ & $\begin{array}{c}1.68^{* * *} \\
(4.16)\end{array}$ & $\begin{array}{c}0.82^{* *} \\
(2.23)\end{array}$ & $\begin{array}{c}1.43^{* * *} \\
(5.06)\end{array}$ & $\begin{array}{c}0.88^{* * *} \\
(5.78)\end{array}$ & $\begin{array}{c}0.59 \\
(1.21)\end{array}$ \\
\hline SIC CODE & 396 & 397 & 399 & 401 & 421 & 422 & 440 & 441 & 442 & 444 & 448 & 449 & 451 & 452 & 458 \\
\hline BITCOIN & $\begin{array}{c}0.69 \\
(0.18)\end{array}$ & $\begin{array}{c}-0.14 \\
(-0.07)\end{array}$ & $\begin{array}{c}-0.20 \\
(-0.33)\end{array}$ & $\begin{array}{c}0.31 \\
(0.55)\end{array}$ & $\begin{array}{c}0.05 \\
(0.09)\end{array}$ & $\begin{array}{c}-0.76 \\
(-0.40)\end{array}$ & $\begin{array}{c}-0.73 \\
(-0.37)\end{array}$ & $\begin{array}{c}-0.83 \\
(-1.19)\end{array}$ & $\begin{array}{c}2.44 \\
(0.58)\end{array}$ & $\begin{array}{c}0.07 \\
(0.08)\end{array}$ & $\begin{array}{c}-0.51 \\
(-0.63)\end{array}$ & $\begin{array}{c}-1.34 \\
(-0.94)\end{array}$ & $\begin{array}{c}0.45 \\
(0.67)\end{array}$ & $\begin{array}{c}0.15 \\
(0.15)\end{array}$ & $\begin{array}{c}0.31 \\
(0.36)\end{array}$ \\
\hline MKTRF & $\begin{array}{c}-0.50 \\
(-0.60)\end{array}$ & $\begin{array}{c}1.87^{* * *} \\
(4.34)\end{array}$ & $\begin{array}{l}1.46^{* * *} \\
(10.67)\end{array}$ & $\begin{array}{c}1.12^{* * *} \\
(9.13)\end{array}$ & $\begin{array}{c}0.98^{* * *} \\
(8.55)\end{array}$ & $\begin{array}{c}0.90 \\
(1.17)\end{array}$ & $\begin{array}{c}1.76^{* * *} \\
(4.07)\end{array}$ & $\begin{array}{c}1.53^{* * *} \\
(9.90)\end{array}$ & $\begin{array}{c}2.66^{* * *} \\
(4.03)\end{array}$ & $\begin{array}{c}1.08^{* * *} \\
(5.24)\end{array}$ & $\begin{array}{c}0.75^{* * *} \\
(4.14)\end{array}$ & $\begin{array}{c}1.92^{* * * *} \\
(6.09)\end{array}$ & $\begin{array}{c}0.99^{* * *} \\
(6.63)\end{array}$ & $\begin{array}{c}1.61^{* * * *} \\
(7.50)\end{array}$ & $\begin{array}{c}0.63^{* * *} \\
(3.35)\end{array}$ \\
\hline SIC CODE & 461 & 472 & 473 & 474 & 478 & 481 & 482 & 483 & 484 & 489 & 491 & 492 & 493 & 494 & 495 \\
\hline BITCOIN & $\begin{array}{c}0.19 \\
(0.31)\end{array}$ & $\begin{array}{c}-3.65 \\
(-1.52)\end{array}$ & $\begin{array}{c}-0.17 \\
(-0.27)\end{array}$ & $\begin{array}{c}-0.58 \\
(-0.57)\end{array}$ & $\begin{array}{c}-5.48^{* * *} \\
(-2.74)\end{array}$ & $\begin{array}{c}0.01 \\
(0.01)\end{array}$ & $\begin{array}{l}-1.77^{*} \\
(-1.78)\end{array}$ & $\begin{array}{c}0.12 \\
(0.25)\end{array}$ & $\begin{array}{c}0.55 \\
(1.26)\end{array}$ & $\begin{array}{c}0.47 \\
(1.00)\end{array}$ & $\begin{array}{c}0.29 \\
(0.56)\end{array}$ & $\begin{array}{l}-0.08 \\
(-0.15)\end{array}$ & $\begin{array}{c}-0.04 \\
(-0.08)\end{array}$ & $\begin{array}{c}-0.27 \\
(-0.48)\end{array}$ & $\begin{array}{c}0.44 \\
(1.06)\end{array}$ \\
\hline MKTRF & $\begin{array}{c}0.80^{* * *} \\
(5.84)\end{array}$ & $\begin{array}{c}0.44 \\
(0.74)\end{array}$ & $\begin{array}{c}0.88^{* * *} \\
(6.24)\end{array}$ & $\begin{array}{c}1.18^{* * *} \\
(4.14)\end{array}$ & $\begin{array}{c}1.71^{* * * *} \\
(4.32)\end{array}$ & $\begin{array}{c}0.56^{* * *} \\
(5.65)\end{array}$ & $\begin{array}{c}0.92^{* * *} \\
(4.17) \\
\end{array}$ & $\begin{array}{c}1.33^{* * *} \\
(13.09)\end{array}$ & $\begin{array}{l}1.05^{* * *} \\
(10.92)\end{array}$ & $\begin{array}{c}0.63^{* * *} \\
(6.08)\end{array}$ & $\begin{array}{c}0.25^{* *} \\
(2.15)\end{array}$ & $\begin{array}{c}0.88^{* * *} \\
(7.28)\end{array}$ & $\begin{array}{l}0.22^{*} \\
(1.85)\end{array}$ & $\begin{array}{c}0.40^{* * *} \\
(3.19)\end{array}$ & $\begin{array}{c}0.47^{* * *} \\
(5.20)\end{array}$ \\
\hline SIC CODE & 501 & 502 & 503 & 504 & 505 & 506 & 507 & 508 & 509 & 511 & 512 & 513 & 514 & 515 & 516 \\
\hline BITCOIN & $\begin{array}{c}-0.18 \\
(-0.41)\end{array}$ & $\begin{array}{l}-1.39 \\
(-0.73)\end{array}$ & $\begin{array}{c}-0.73 \\
(-1.07)\end{array}$ & $\begin{array}{c}0.20 \\
(0.45)\end{array}$ & $\begin{array}{l}-1.25 \\
(-1.63)\end{array}$ & $\begin{array}{c}-0.43 \\
(-1.06)\end{array}$ & $\begin{array}{c}-0.67 \\
(-0.89)\end{array}$ & $\begin{array}{c}-0.59 \\
(-0.88)\end{array}$ & $\begin{array}{c}0.75 \\
(1.07)\end{array}$ & $\begin{array}{c}-1.32 \\
(-0.93)\end{array}$ & $\begin{array}{c}0.95 \\
(1.45)\end{array}$ & $\begin{array}{c}-0.30 \\
(-0.27)\end{array}$ & $\begin{array}{c}0.64 \\
(1.40)\end{array}$ & $\begin{array}{c}-0.60 \\
(-0.74)\end{array}$ & $\begin{array}{c}-0.29 \\
(-0.42)\end{array}$ \\
\hline MKTRF & $\begin{array}{l}1.05^{* * *} \\
(10.50)\end{array}$ & $\begin{array}{c}1.35^{* * *} \\
(3.19)\end{array}$ & $\begin{array}{c}1.50^{* * *} \\
(9.85)\end{array}$ & $\begin{array}{l}1.01^{* * *} \\
(10.45)\end{array}$ & $\begin{array}{l}1.71^{* * *} \\
(10.05)\end{array}$ & $\begin{array}{l}1.23^{* * *} \\
(13.86)\end{array}$ & $\begin{array}{c}1.00^{* * *} \\
(5.95)\end{array}$ & $\begin{array}{c}0.92^{* * *} \\
(6.22)\end{array}$ & $\begin{array}{c}1.08^{* * *} \\
(7.01)\end{array}$ & $\begin{array}{c}1.33^{* * *} \\
(4.25)\end{array}$ & $\begin{array}{c}0.88^{* * *} \\
(6.05)\end{array}$ & $\begin{array}{c}1.03^{* * *} \\
(4.16)\end{array}$ & $\begin{array}{c}0.63^{* * *} \\
(6.19)\end{array}$ & $\begin{array}{c}1.20^{* * *} \\
(6.79)\end{array}$ & $\begin{array}{c}1.48^{* * *} \\
(9.73)\end{array}$ \\
\hline
\end{tabular}




\begin{tabular}{|c|c|c|c|c|c|c|c|c|c|c|c|c|c|c|c|}
\hline SIC CODE & 517 & 518 & 519 & 520 & 521 & 523 & 531 & 533 & 539 & 541 & 544 & 546 & 549 & 551 & 552 \\
\hline \multirow[t]{2}{*}{ BITCOIN } & -0.48 & 0.52 & -1.37 & -1.42 & $-1.40^{* *}$ & -1.02 & 0.31 & 0.45 & -1.25 & -0.79 & 0.29 & -0.15 & $3.32^{* *}$ & -0.26 & 0.22 \\
\hline & $(-0.72)$ & $(0.81)$ & $(-1.32)$ & $(-1.55)$ & $(-2.53)$ & $(-1.24)$ & $(0.35)$ & $(0.85)$ & $(-0.46)$ & $(-0.98)$ & $(0.45)$ & $(-0.07)$ & $(2.59)$ & $(-0.27)$ & $(0.19)$ \\
\hline MKTRF & $1.21^{* * *}$ & $0.58^{* * *}$ & $1.41^{* * *}$ & $0.99^{* * *}$ & $1.08^{* * *}$ & $0.91^{* * *}$ & $0.83^{* * *}$ & $0.46^{* * *}$ & 0.98 & $0.79^{* * *}$ & $0.67^{* * *}$ & $0.84^{*}$ & $0.86^{* * *}$ & $1.38^{* * *}$ & $1.55^{* * *}$ \\
\hline SIC CODE & 553 & 554 & 555 & 560 & 561 & 562 & 563 & 564 & 565 & 566 & 569 & 570 & 571 & 572 & 573 \\
\hline BITCOIN & -0.52 & 0.32 & -0.37 & -0.17 & 0.83 & 0.88 & 0.67 & -0.95 & 0.22 & -0.74 & -1.92 & 1.07 & 0.27 & 3.38 & 0.18 \\
\hline \multirow[t]{2}{*}{ MKTRF } & $0.58^{* * *}$ & $0.68^{* * *}$ & $1.31^{* * *}$ & $0.86^{* *}$ & $0.89^{* *}$ & $0.96^{* * *}$ & $1.42^{* * *}$ & $1.10^{* * *}$ & $0.94^{* * *}$ & $0.92^{* * *}$ & 0.45 & $0.68^{* * *}$ & $1.31^{* * *}$ & 1.39 & $1.10^{* * *}$ \\
\hline & $(3.51)$ & $(4.47)$ & $(4.52)$ & $(2.62)$ & $(2.54)$ & $(3.95)$ & $(3.44)$ & $(3.38)$ & $(5.67)$ & $(3.90)$ & $(1.36)$ & $(2.89)$ & $(6.07)$ & $(1.65)$ & $(3.64)$ \\
\hline SIC CODE & 581 & 590 & 591 & 593 & 594 & 596 & 598 & 599 & 600 & 601 & 602 & 603 & 608 & 609 & 611 \\
\hline \multirow[t]{2}{*}{ BITCOIN } & 0.33 & 1.83 & 0.87 & 0.06 & -0.35 & -0.35 & 0.43 & -0.27 & -1.24 & -0.27 & -0.36 & -0.34 & -2.12 & -0.90 & $-2.44^{*}$ \\
\hline & $(0.86)$ & $(1.49)$ & $(1.36)$ & $(0.06)$ & $(-0.53)$ & $(-0.39)$ & $(0.23)$ & $(-0.45)$ & $(-1.27)$ & $(-0.26)$ & $(-0.85)$ & $(-0.74)$ & $(-1.65)$ & $(-1.22)$ & $(-1.70)$ \\
\hline \multirow[t]{2}{*}{ MKTRF } & $0.57^{* * *}$ & $0.87^{* * *}$ & $0.87^{* * *}$ & $0.73^{* * *}$ & $1.48^{* * *}$ & $0.88^{* * *}$ & $1.76^{* * *}$ & $0.76^{* * *}$ & $1.04^{* * *}$ & 0.28 & $1.29^{* * *}$ & $0.98^{* * *}$ & $1.20^{* * *}$ & $1.09^{* * *}$ & $1.22^{* * *}$ \\
\hline & $(6.67)$ & $(3.19)$ & $(6.20)$ & $(3.27)$ & (10.19) & $(4.41)$ & $(4.15)$ & $(5.83)$ & $(4.83)$ & $(1.24)$ & $(13.71)$ & $(9.57)$ & $(3.87)$ & $(6.71)$ & $(3.84)$ \\
\hline SIC CODE & 614 & 615 & 616 & 619 & 620 & 621 & 622 & 623 & 628 & 630 & 631 & 632 & 633 & 635 & 636 \\
\hline \multirow[t]{2}{*}{ BITCOIN } & 0.51 & 0.77 & 0.18 & -1.25 & 0.15 & -0.75 & 0.31 & 1.33 & 0.16 & -0.30 & 0.19 & 0.78 & $-0.52^{*}$ & 0.25 & 0.22 \\
\hline & $(0.82)$ & $(1.44)$ & $(0.12)$ & $(-1.11)$ & $(0.22)$ & $(-1.18)$ & $(0.33)$ & $(1.28)$ & $(0.54)$ & $(-0.30)$ & $(0.34)$ & $(1.52)$ & $(-1.75)$ & $(0.44)$ & $(0.38)$ \\
\hline \multirow[t]{2}{*}{ MKTRF } & $1.11^{* * *}$ & $0.96^{* * *}$ & $1.16^{* * *}$ & $0.99^{* * *}$ & $0.88^{* * *}$ & $1.69^{* * *}$ & $0.80^{* * *}$ & $1.08^{* * *}$ & $1.60^{* * *}$ & $0.85^{* * *}$ & $1.65^{* * *}$ & $0.88^{* * *}$ & $0.88^{* * *}$ & $1.47^{* * *}$ & $0.66^{* * *}$ \\
\hline & $(8.14)$ & $(8.19)$ & $(3.55)$ & $(3.83)$ & $(5.84)$ & $(12.00)$ & $(3.81)$ & $(4.73)$ & $(25.22)$ & $(3.84)$ & $(13.26)$ & $(7.73)$ & (13.48) & $(11.81)$ & $(5.29)$ \\
\hline SIC CODE & 637 & 639 & 641 & 650 & 651 & 653 & 655 & 670 & 671 & 672 & 673 & 677 & 679 & 701 & 720 \\
\hline \multirow[t]{2}{*}{ BITCOIN } & -0.15 & 1.24 & -0.04 & -0.38 & 0.14 & -0.20 & -0.70 & 0.31 & -0.36 & -0.13 & $-2.85^{* *}$ & -0.71 & -0.26 & -0.29 & -0.01 \\
\hline & $(-0.19)$ & $(1.34)$ & $(-0.10)$ & $(-0.33)$ & $(0.26)$ & $(-0.45)$ & $(-0.86)$ & $(0.09)$ & $(-0.69)$ & $(-0.87)$ & $(-2.37)$ & $(-0.43)$ & $(-0.56)$ & $(-0.52)$ & $(-0.01)$ \\
\hline \multirow[t]{2}{*}{ MKTRF } & $0.82^{* * *}$ & $0.98^{* * *}$ & $0.95^{* * *}$ & $0.49^{*}$ & $1.08^{* * *}$ & $1.45^{* * *}$ & $0.94^{* * *}$ & 0.93 & $1.33^{* * *}$ & $0.76^{* * *}$ & $1.66^{* * *}$ & $1.24^{* * *}$ & $0.81^{* * *}$ & $1.59^{* * *}$ & $0.86^{* * *}$ \\
\hline & $(3.64)$ & $(4.82)$ & $(11.87)$ & $(1.90)$ & $(9.08)$ & $(14.74)$ & $(5.23)$ & $(1.27)$ & $(11.48)$ & $(23.03)$ & $(6.19)$ & $(3.35)$ & $(7.83)$ & $(12.87)$ & $(2.96)$ \\
\hline
\end{tabular}




\begin{tabular}{|c|c|c|c|c|c|c|c|c|c|c|c|c|c|c|c|}
\hline SIC CODE & 721 & 723 & 726 & 728 & 729 & 731 & 732 & 733 & 734 & 735 & 736 & 737 & 738 & 751 & 753 \\
\hline BITCOIN & -0.96 & 0.24 & -0.48 & -1.06 & 1.28 & -0.45 & -0.27 & -1.67 & -0.53 & -0.62 & -0.84 & 0.01 & 0.08 & 0.67 & 0.69 \\
\hline \multirow{3}{*}{ MKTRF } & $(-1.45)$ & $(0.25)$ & $(-0.77)$ & $(-0.76)$ & $(0.92)$ & $(-0.88)$ & $(-0.56)$ & $(-1.26)$ & $(-1.14)$ & $(-0.89)$ & $(-1.57)$ & $(0.03)$ & $(0.21)$ & $(0.66)$ & $(0.61)$ \\
\hline & $1.07^{* * *}$ & $0.86^{* * *}$ & $1.05^{* * *}$ & $1.22^{* * *}$ & $1.68^{* * *}$ & $1.57^{* * *}$ & $1.10^{* * *}$ & $1.56^{* * *}$ & $0.72^{* * *}$ & $1.77^{* * *}$ & $1.61^{* * *}$ & $1.04^{* * *}$ & $1.05^{* * *}$ & $1.85^{* * *}$ & $0.75^{* * *}$ \\
\hline & $(7.28)$ & $(4.09)$ & $(7.54)$ & $(3.38)$ & $(5.42)$ & $(13.96)$ & $(10.41)$ & $(5.31)$ & $(7.03)$ & $(11.50)$ & (13.61) & (13.46) & $(12.46)$ & $(8.23)$ & $(2.99)$ \\
\hline SIC CODE & 781 & 782 & 783 & 784 & 790 & 792 & 793 & 794 & 799 & 800 & 801 & 802 & 805 & 806 & 807 \\
\hline \multirow[t]{2}{*}{ BITCOIN } & -0.56 & 0.43 & -0.47 & 2.33 & -0.57 & -0.03 & 0.14 & 0.76 & 0.18 & $-5.45^{*}$ & 0.31 & 1.31 & -0.35 & -0.58 & 0.09 \\
\hline & $(-0.67)$ & $(0.24)$ & $(-0.55)$ & $(0.82)$ & $(-0.26)$ & $(-0.03)$ & $(0.28)$ & $(1.50)$ & $(0.27)$ & $(-1.81)$ & $(0.35)$ & $(0.72)$ & $(-0.40)$ & $(-0.61)$ & $(0.15)$ \\
\hline \multirow[t]{2}{*}{ MKTRF } & $1.14^{* * *}$ & $0.91 * *$ & $1.06^{* * *}$ & $1.44^{* *}$ & 0.58 & $1.17^{* * *}$ & $0.23^{* *}$ & $0.89^{* * *}$ & $1.21^{* * *}$ & 0.59 & $0.62^{* * *}$ & -0.06 & $1.61^{* * *}$ & $1.11^{* * *}$ & $0.82^{* * *}$ \\
\hline & $(6.09)$ & $(2.27)$ & $(5.56)$ & $(2.30)$ & $(1.15)$ & $(5.19)$ & $(2.05)$ & $(7.89)$ & $(8.24)$ & $(0.78)$ & $(3.22)$ & $(-0.15)$ & $(8.41)$ & $(5.32)$ & $(6.06)$ \\
\hline SIC CODE & 808 & 809 & 820 & 821 & 822 & 823 & 824 & 829 & 830 & 832 & 835 & 836 & 869 & 870 & 871 \\
\hline \multirow[t]{2}{*}{ BITCOIN } & $1.56^{*}$ & 0.53 & -1.04 & 1.39 & -0.33 & 6.64 & -0.12 & 1.07 & -2.17 & -1.57 & -0.10 & 0.84 & -1.31 & 0.51 & $-0.87^{*}$ \\
\hline & $(1.81)$ & $(0.83)$ & $(-0.61)$ & $(0.76)$ & $(-0.25)$ & $(1.02)$ & $(-0.08)$ & $(0.75)$ & $(-0.42)$ & $(-0.95)$ & $(-0.12)$ & $(0.54)$ & $(-0.65)$ & $(0.99)$ & $(-1.73)$ \\
\hline \multirow[t]{2}{*}{ MKTRF } & $0.79^{* * *}$ & $1.23^{* * *}$ & $1.38^{* * *}$ & $1.35^{* * *}$ & $1.31^{* * *}$ & $1.82^{* * *}$ & $1.29^{* * *}$ & $1.30^{* * *}$ & 0.39 & $1.13^{* * *}$ & 0.16 & $1.44^{* * *}$ & $1.57^{* * *}$ & $0.87^{* * *}$ & $1.39^{* * *}$ \\
\hline & $(4.16)$ & $(8.79)$ & $(3.68)$ & $(3.34)$ & $(4.46)$ & $(3.34)$ & $(4.01)$ & $(4.12)$ & $(0.39)$ & $(3.11)$ & $(0.68)$ & $(4.22)$ & $(3.81)$ & $(7.59)$ & (12.44) \\
\hline SIC CODE & 872 & 873 & 874 & 891 & 899 & 943 & 951 & 961 & 999 & & & & & & \\
\hline BITCOIN & 0.48 & 0.81 & -0.13 & -0.21 & 0.48 & 1.21 & -2.93 & $-3.30^{* *}$ & -0.42 & & & & & & \\
\hline & $(0.49)$ & $(0.98)$ & $(-0.36)$ & $(-0.13)$ & $(0.32)$ & $(0.57)$ & $(-0.55)$ & $(-2.05)$ & $(-0.94)$ & & & & & & \\
\hline MKTRF & $1.10^{* * *}$ & $1.18^{* * *}$ & $0.98^{* * *}$ & $0.83^{* *}$ & $1.22^{* * *}$ & $1.10^{* *}$ & $2.83^{* *}$ & $1.35^{* * *}$ & $1.16^{* * *}$ & & & & & & \\
\hline & $(5.06)$ & $(6.48)$ & (12.11) & $(2.35)$ & $(3.68)$ & $(2.22)$ & $(2.61)$ & $(4.54)$ & $(11.54)$ & & & & & & \\
\hline
\end{tabular}




\section{Appendix B: Implied Risk Neutral Disaster Probability}

In this section, we calculate the risk neutral disaster probability that can justify the realized high average cryptocurrency returns. We define a disaster as an event where the cryptocurrency price drops to zero in one day. We further calculate the average cryptocurrency return as the trailing one year average daily return. When the implied risk neutral disaster probability is negative, we modify it to zero. Figure A.3 plots the time-varying implied risk neutral disaster probability of Bitcoin, Ripple, and Ethereum, respectively. The implied disaster probability ranges from 0 to 1.3 percent for Bitcoin, 0 to 2.5 percent for Ripple, and 0.4 to 1.6 percent for Ethereum. The current implied daily disaster probability is about 0.4 percent for Bitcoin, 0.6 percent for Ripple, and 0.3 percent for Ethereum.

Figure A.3: Implied Risk Neutral Disaster Probability
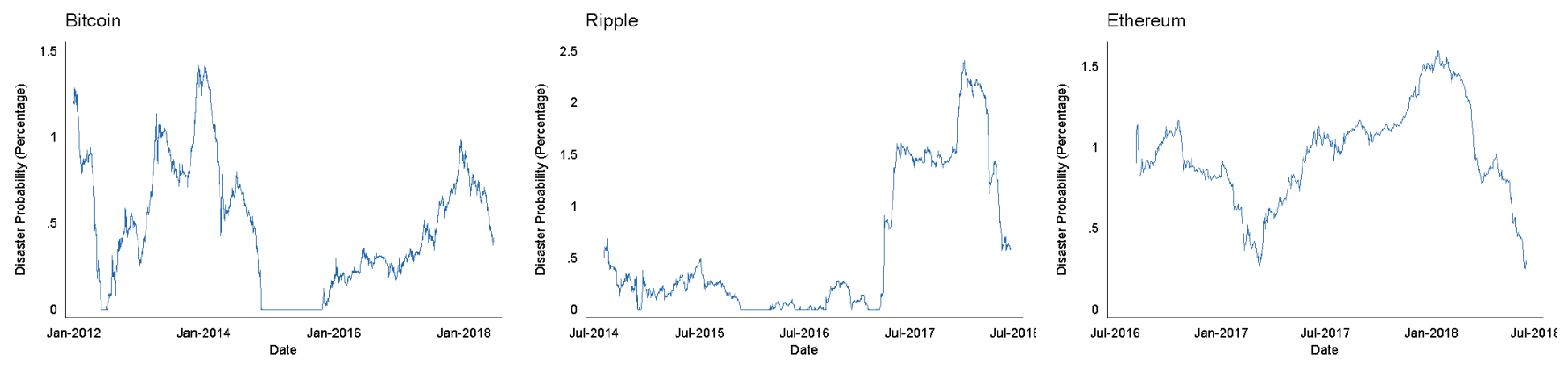

\section{Appendix C: Portfolio Choice with Cryptocurrency}

In this section, we ask the question: how much cryptocurrency an investor should hold in her portfolio? To answer this question, we use the Black-Litterman model (Black and Litterman $(1990,1992)$ ) and evaluate the optimal portfolio problem. The variable notations used in this section are the same as in He and Litterman (1999). We separately investigate incorporating Bitcoin into a portfolio with only stocks, a portfolio with stocks and corporate bonds, and a portfolio with stocks, bonds and currency. Following He and Litterman (1999), we assume a risk aversion parameter of 2.5. The coefficient of uncertainty in the prior estimate of the mean, $\tau$, is assumed to be 0.30 or $30 \%$ - a very conservative estimate reflecting the high volatility of Bitcoin returns.

Table A.6 shows the correlation structure of Bitoin and other assets including stocks, coprorate bonds, and currency. Table A.7 reports the standard deviations of the returns of the assets, market capitalization shares, and CAPM implied equilibrium risk premiums.

The Black-Litterman model allows us to incorporate different investor views into the portfolio allocation problem. We investigate a range of investor views and their effect on the allocation of Bitcoin. The different investor views we examine are (1) Bitcoin will outperform the rest of the assets by 30 percent a year, (2) Bitcoin will outperform the rest of the assets by 50 percent a year, (3) Bitcoin will outperform the rest of the assets by 100 percent per year, and (4) Bitcoin will outperform the rest of the assets by 200 percent a year. Historically, Bitcoin has been outperforming the rest of the assets by about 200 percent a year. Across the different portfolios we considered, the shares of Bitcoin under the different investor views are similar. The 
investor should have about 1 percent, 1.6 percent, 3.1 percent, and 6.1 percent share of Bitcoin under views (1), (2), (3), and (4), respectively. That is, if the investor believes Bitcoin will continue to do as well as the past seven years, she should hold about 6.1 percent share of Bitcoin in her portfolio. Even if the investor believes Bitcoin will only have half of its historical performance going forward, she should still hold about 3.1 percent share of Bitcoin in her portfolio.

Table A.6: Correlations of Different Asset Classes

\begin{tabular}{lcccc}
\hline & Bitcoin & Stock & Corporate & Currency \\
\hline Bitcoin & 1.00 & & & \\
Stock & 0.16 & 1.00 & & \\
Corporate & -0.04 & -0.30 & 1.00 & \\
Currency & 0.08 & 0.55 & -0.08 & 1.00 \\
\hline
\end{tabular}

Table A.7: Annualized Volatility, Market Cap Weights, and Equilibrium Risk Premiums

\begin{tabular}{lccc}
\hline Panel A & $\sigma$ & $w_{e q}$ & $\Pi$ \\
\hline Bitcoin & 2.41 & $0.61 \%$ & $19.57 \%$ \\
Stock & 0.11 & $99.39 \%$ & $3.20 \%$ \\
& & & \\
\hline Panel B & $\sigma$ & $w_{e q}$ & $\Pi$ \\
\hline & & & \\
Bitcoin & 2.41 & $0.45 \%$ & $13.65 \%$ \\
Stock & 0.11 & $72.39 \%$ & $2.09 \%$ \\
Corporate & 0.10 & $27.16 \%$ & $0.09 \%$ \\
& & & \\
\hline Panel C & $\sigma$ & $w_{e q}$ & $\Pi$ \\
\hline Bitcoin & 2.41 & $0.39 \%$ & $12.21 \%$ \\
Stock & 0.11 & $62.40 \%$ & $1.93 \%$ \\
Corproate & 0.10 & $23.41 \%$ & $0.06 \%$ \\
Currency & 0.06 & $13.80 \%$ & $0.71 \%$ \\
& & &
\end{tabular}


Table A.8: Optimal Portfolio Weights under Different Investor Views

\begin{tabular}{|c|c|c|c|c|}
\hline \multicolumn{5}{|l|}{ Panel A: Two Assets } \\
\hline Outperform Other Assets by $30 \%$ & $p$ & $\mu$ & $w^{*}$ & $w^{*}-\frac{w_{e q}}{1+\tau}$ \\
\hline Bitcoin & 100 & $26.42 \%$ & 1.00 & 0.53 \\
\hline Stock & -100 & $3.23 \%$ & 75.92 & -0.53 \\
\hline Outperform Other Assets by $50 \%$ & $p$ & $\mu$ & $w^{*}$ & $w^{*}-\frac{w_{e q}}{1+\tau}$ \\
\hline Bitcoin & 100 & $36.47 \%$ & 1.61 & 1.14 \\
\hline Stock & -100 & $3.29 \%$ & 75.32 & -1.14 \\
\hline Outperform Other Assets by $100 \%$ & $p$ & $\mu$ & $w^{*}$ & $w^{*}-\frac{w_{e q}}{1+\tau}$ \\
\hline Bitcoin & 100 & $61.6 \%$ & 3.13 & 2.66 \\
\hline Stock & -100 & $3.42 \%$ & 73.79 & -2.66 \\
\hline Outperform Other Assets by $200 \%$ & $p$ & $\mu$ & $w^{*}$ & $w^{*}-\frac{w_{e q}}{1+\tau}$ \\
\hline Bitcoin & 100 & $111.9 \%$ & 6.12 & 5.70 \\
\hline Stock & -100 & $3.69 \%$ & 70.75 & -5.70 \\
\hline \multicolumn{5}{|l|}{ Panel B: Three Assets } \\
\hline Outperform Other Assets by $30 \%$ & $p$ & $\mu$ & $w^{*}$ & $w^{*}-\frac{w_{e q}}{1+\tau}$ \\
\hline Bitcoin & 100 & $22.63 \%$ & 0.97 & 0.63 \\
\hline Stock & -72.71 & $2.15 \%$ & 55.23 & -0.46 \\
\hline Corporate & -27.29 & $0.07 \%$ & 20.72 & -0.17 \\
\hline Outperform Other Assets by $50 \%$ & $p$ & $\mu$ & $w^{*}$ & $w^{*}-\frac{w_{e q}}{1+\tau}$ \\
\hline Bitcoin & 100 & $32.67 \%$ & 1.58 & 1.23 \\
\hline Stock & -72.71 & $2.21 \%$ & 54.79 & -0.90 \\
\hline Corporate & -27.29 & $0.05 \%$ & 20.56 & -0.34 \\
\hline Outperform Other Assets by $100 \%$ & $p$ & $\mu$ & $w^{*}$ & $w^{*}-\frac{w_{e q}}{1+\tau}$ \\
\hline Bitcoin & 100 & $57.55 \%$ & 3.10 & 2.75 \\
\hline Stock & -72.71 & $2.36 \%$ & 53.69 & -2.00 \\
\hline Corporate & -27.29 & $0.01 \%$ & 20.14 & -0.75 \\
\hline Outperform Other Assets by $200 \%$ & $p$ & $\mu$ & $w^{*}$ & $w^{*}-\frac{w_{e q}}{1+\tau}$ \\
\hline Bitcoin & 100 & $108.00 \%$ & 6.13 & 5.78 \\
\hline Stock & -72.71 & $2.66 \%$ & 51.48 & -4.20 \\
\hline Corporate & -27.29 & $-0.08 \%$ & 19.32 & -1.58 \\
\hline
\end{tabular}




\begin{tabular}{|c|c|c|c|c|}
\hline \multicolumn{5}{|l|}{ Panel C: Four Assets } \\
\hline Outperform Other Assets by $30 \%$ & $p$ & $\mu$ & $w^{*}$ & $w^{*}-\frac{w_{e q}}{1+\tau}$ \\
\hline Bitcoin & 100 & $21.80 \%$ & 0.96 & 0.66 \\
\hline Stock & -62.64 & $1.99 \%$ & 47.59 & -0.41 \\
\hline Corporate & -23.50 & $0.04 \%$ & 17.85 & -0.15 \\
\hline Currency & -13.86 & $0.72 \%$ & 10.52 & -0.09 \\
\hline Outperform Other Assets by $50 \%$ & $p$ & $\mu$ & $w^{*}$ & $w^{*}-\frac{w_{e q}}{1+\tau}$ \\
\hline Bitcoin & 100 & $31.84 \%$ & 1.56 & 1.26 \\
\hline Stock & -62.64 & $2.06 \%$ & 47.21 & -0.79 \\
\hline Corporate & -23.50 & $0.02 \%$ & 17.71 & -0.30 \\
\hline Currency & -13.86 & $0.74 \%$ & 10.44 & -0.17 \\
\hline Outperform Other Assets by $100 \%$ & $p$ & $\mu$ & $w^{*}$ & $w^{*}-\frac{w_{e q}}{1+\tau}$ \\
\hline Bitcoin & 100 & 56.93 & 3.08 & 2.78 \\
\hline Stock & -62.64 & 2.21 & 46.26 & -1.74 \\
\hline Corporate & -23.50 & -0.02 & 17.36 & -0.65 \\
\hline Currency & -13.86 & 0.78 & 10.23 & -0.38 \\
\hline Outperform Other Assets by $200 \%$ & $p$ & $\mu$ & $w^{*}$ & $w^{*}-\frac{w_{e q}}{1+\tau}$ \\
\hline Bitcoin & 100 & $107.10 \%$ & 6.10 & 5.804 \\
\hline Stock & -62.64 & $2.52 \%$ & 44.36 & -3.64 \\
\hline Corporate & -23.50 & $-0.11 \%$ & 16.64 & -1.36 \\
\hline Currency & -13.86 & $0.86 \%$ & 9.81 & -0.80 \\
\hline
\end{tabular}

